\title{
AS VIVÊNCIAS DA MATERNIDADE NA ADOLESCÊNCIA MENOR
}

\section{Sílvia Reis dos SANTOS}

Tese de Doutorado apresentada ao Departamento de Saúde Materno-Infantil da Faculdade de Saúde Pública da Universidade de São Paulo para obtenção do Grau de Doutor.

Área de concentração: Saúde maternoinfantil

Orientadora: Prof. Assoc. Néia Schor

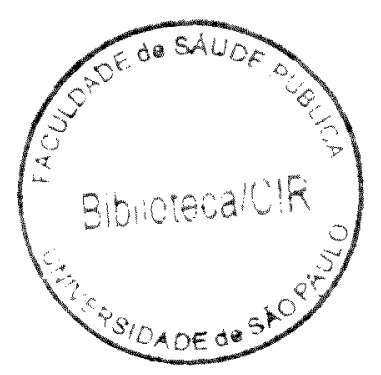

São Paulo

2001 
Autorizo, exclusivamente para fins acadêmicos e científicos, a reprodução total ou parcial desta tese, por processos fotocopiadores.

Assinatura:

Data:

$413861200100 x$ 
A todos os profissionais de saúde que não desistem e ainda ousam sonhar 


\section{AGRADECIMENTOS:}

Ao meu querido Lucio, marido, amigo, companheiro e mestre na vida, pela ajuda, incentivo, tolerância e amor;

Aos meus queridos pais Alcides e Carmen Sylvia e à minha irmã Christina, por todo o amor que sempre me deram e ainda me dão e pelo exemplo de seriedade e respeito ao trabalho e à educação;

À minha orientadora Prof. Néia Schor, por sua competência e ética, por sua firme orientação, amizade e confiança;
À Direção do Instituto de Puericultura e Pediatria Martagão Gesteira da Universidade Federal do Rio de Janeiro (IPPMG) e à Direção da Fundaçāo Educacional Serra dos Órgãos (FESO), pela compreensão da importância deste momento e liberação de minhas atividades;

Aos colegas das Divisões de Ensino e de Pesquisa do IPPMG e do Núcleo de Pós-Graduação, Pesquisa e Extensão da FESO, pela amizade, incentivo e tolerância nas necessárias ausências;

À toda a equipe do Ambulatório Materno-Infantil do IPPMG, amigos e companheiros de tantas jornadas, e, em particular, à auxiliar de enfermagem Maria das Graças Quitete e às outras profissionais do setor de pesagem, pela inestimável ajuda na identificação dos sujeitos da pesquisa; sem vocês este trabalho não poderia ter sido feito; 
Aos profissionais da Unidade Integrada de Saúde Hamilton Land (em particular à Dra. Irene Fagim), Posto de Assistência Médica Madre Tereza de Calcutá (em particular ao Dr. Moreno) e Posto de Assistência Médica Rodolpho Rocco (em particular à Dra. Rosa Obadia), pelo compromisso com a saúde da adolescente, que tão bem souberam demonstrar, pela acolhida e pela ajuda na coleta dos dados;

À administração dos colégios Ginda Bloch e Edmundo Bittencourt, em Teresópolis, pela gentil acolhida, e a todas as adolescentes que compuseram os grupos focais, pelo entusiasmo e participação;

A todos os funcionários do Departamento Materno-Infantil da Faculdade de Saúde Pública da Universidade de São Paulo pela competência, simpatia e auxilio em momentos de dificuldades;

Aos Profs. Robert Mrtek da University of Illinois at Chicago, Steven Brown da Kent State University e Michael Stricklin da University of Nebraska at Lincoln, por terem me introduzido nos mistérios e desafios da Metodologia Q;

Ao CNPq, pela bolsa de estudos concedida;

E a todos os que me precederam no estudo da saúde materno-infantil e do adolescente,

meu reconhecimento e sinceros agradecimentos. 


\section{RESUMO}

Santos SR. As vivências da maternidade na adolescência menor. São

Paulo; 2001. [Tese de Doutorado - Faculdade de Saúde Pública da USP].

Objetivo. Embora pouco estudada em nosso meio, a maternidade na adolescência de 10 a 14 anos é considerada não desejada e problema de Saúde Pública. A maior parte dos estudos tem o conceitual crono-biomédico como marco teórico, e poucos abordam esta questão a partir do olhar do sujeito. Este estudo teve por objetivo explorar padrões e desvendar as diferentes formas de vivenciar a maternidade na adolescência menor a partir da subjetividade da própria adolescente. Métodos. Utilizou-se a Metodologia $Q$ de William Stephenson. Captadas em dois serviços públicos de saúde materno-infantil no Municipio do Rio de Janeiro, vinte adolescentes que ficaram grávidas entre 10 e 14 anos de idade foram estudadas em periodo de seis a 24 meses após o nascimento de seus respectivos filhos. Os Qsorts foram submetidos a análise fatorial, e os fatores obtidos foram interpretados. Resultados. Foram revelados quatro padrōes de percepção, qualitativa e estatisticamente diferentes $(P<0,01)$. Dois fatores foram bem definidos: Fator I - Satisfeita com a maternidade / Dependente do afeto do filho: a maternidade como uma vivência positiva e enriquecedora e Fator II Deprimida/ Estressada: visão negativa e fragilizante. Outros dois fatores, ainda incipientes, necessitam confirmaçāo em estudo posterior com amostra mais numerosa: Fator III - Adaptada / Dependente da familia: a maternidade como experiência positiva de estreitamento de vínculos familiares; e Fator IV - Contraditória / Em busca de identidade e apoio: vivência em conflito com os 
valores sociais. Conclusões. A partir da subjetividade da própria adolescente, foi possivel observar que a vivência da maternidade não é única nem homogênea. Para algumas adolescentes, ser mãe pode ser uma experiência gratificante.

Descritores: Adolescência. Gravidez na adolescência. Q-sort. 


\section{SUMMARY}

\section{Santos SR. As vivências da maternidade na adolescência menor}

[Experiences of motherhood in early adolescence]. São Paulo (BR); 2001.

[Tese de Doutorado - Faculdade de Saúde Pública da Universidade de São Paulo].

Objective. Although considered unwanted and an important Public Health issue, motherhood in early adolescency is still little studied. Most investigations are based on the biomedical paradigm and few take into consideration the adolescent point-of-view. This study aimed to explore different patterns of experiencing motherhood from the adolescent own subjectivity. Methods. William Stephenson's Q Methodology was used. Identified at two public mother and child health units in Rio de Janeiro, Brazil, twenty adolescents who became pregnant at the age of 10 to 14 years were studied in a period of time from six to 24 months after the child's birth. Qsorts were factor analyzed and factors interpreted. Results. Four qualitatively and statistically $(P<0,01)$ different patterns of perceptions were revealed. Two factors were well defined: Factor I - Satisfied with motherhood I Dependent on the child's affection: motherhood is a positive and rich experience and Factor II - Depressed / Stressed: motherhood is a negative and stressful experience. Other two possible factors need confirmation in further studies with expanded samples: Fator III - Well adapted / Family oriented: motherhood is a positive experience that reinforces family bonds and Fator IV - Contradictory / Searching identity: conflicts with social values. Conclusions. From the adolescents' own points-of-view, it was possible to 
observe that the experience of motherhood is diverse and heterogeneous

For some adolescents, motherhood can be a positive experience.

Descriptors: Adolescence. Pregnancy in adolescence. Q-sort. 


\section{ÍNDICE}

PÁG.

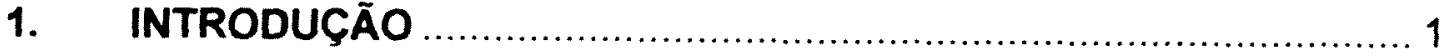

1.1. Revisão da literatura ............................................................. 3

1.1.1. Adolescência e adolescentes - definições ......................... 3

1.1.2. Magnitude do fenômeno .................................................. 8

1.1.3. Sexualidade na adolescência ......................................... 9

1.1.4. Fecundidade na adolescência .................................... 10

1.1.5. A maternidade na adolescência .................................. 19

1.1.6. Programas de saúde do adolescente ............................. 24

1.2. Consenso e controvérsias ................................................ 27

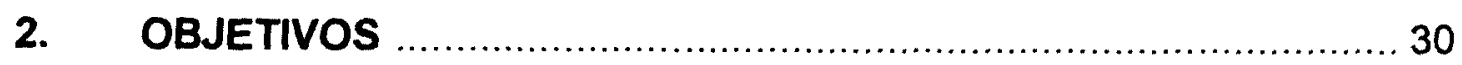

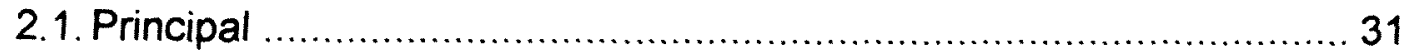

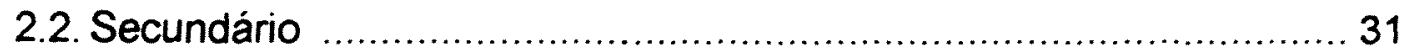

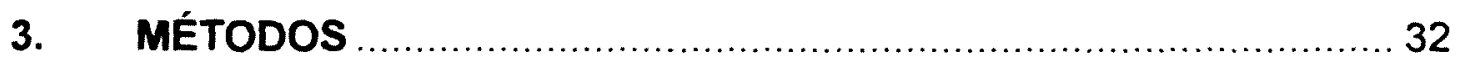

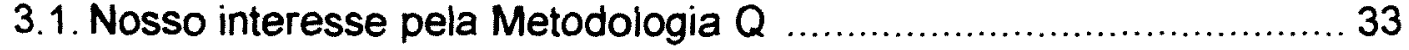

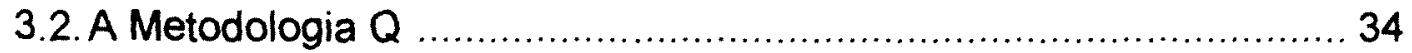

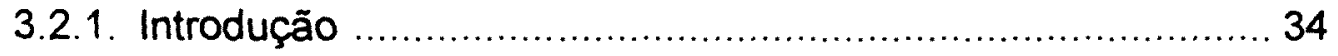

3.2.2. Referencial teórico ............................................ 36

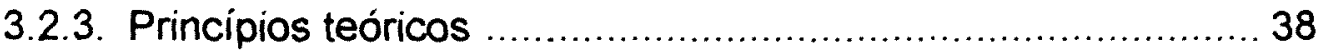

3.2.4. A Metodologia $Q$ - estratégia privilegiada para o estudo da subjetividade ......................................................... 39

3.2.5. O método $Q$............................................................. 42

3.2.6. Etapas para a realização de um estudo $Q$....................... 45

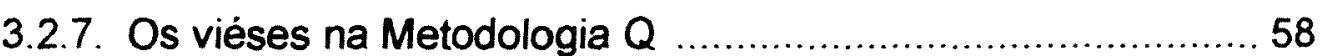

3.3. Local e sujeitos de estudo ...................................................60 60

3.3.1. Aspectos éticos .......................................................... 60

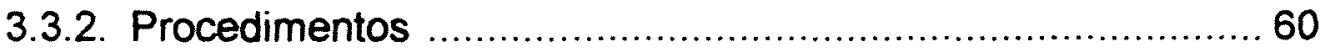

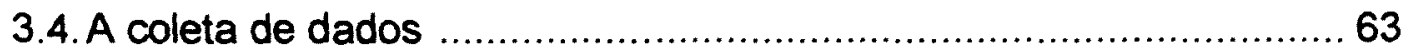

3.4.1. Elaboração do concourse of ideas ............................... 63

3.4.2. Coleta de dados propriamente dita ................................65

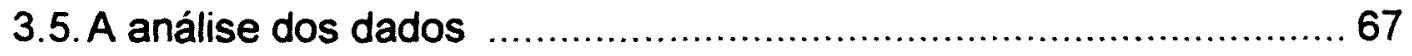

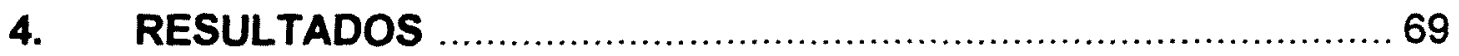

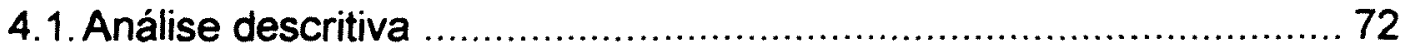




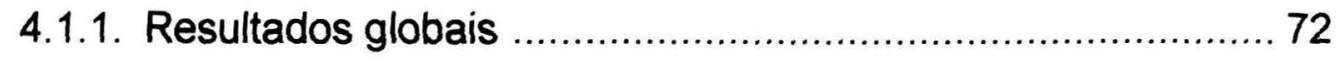

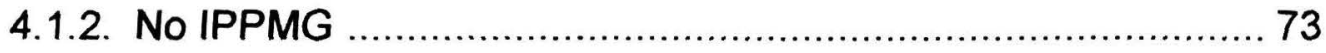

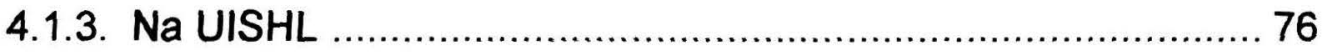

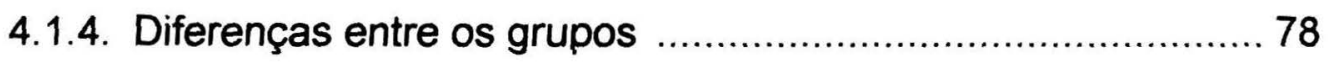

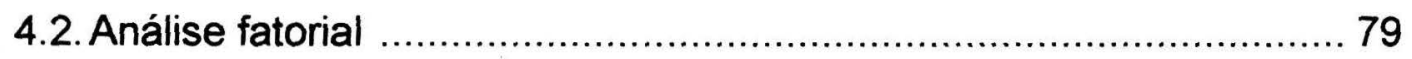

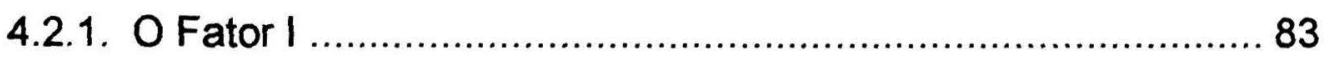

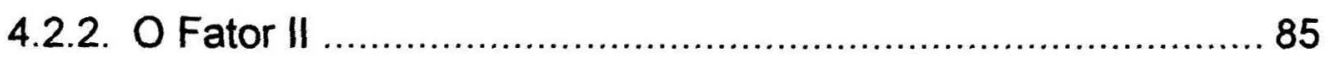

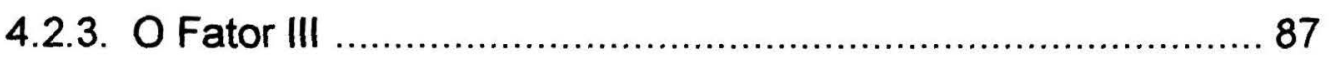

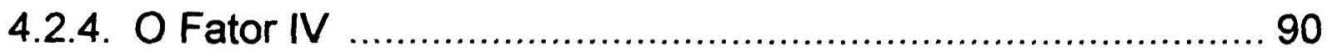

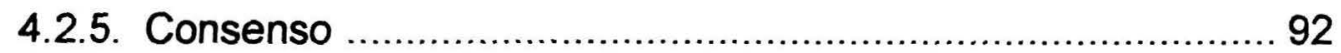

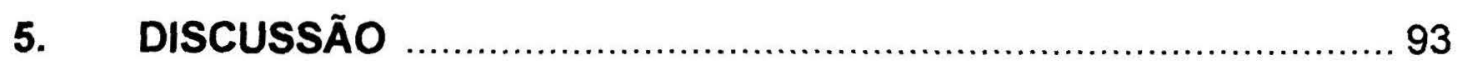

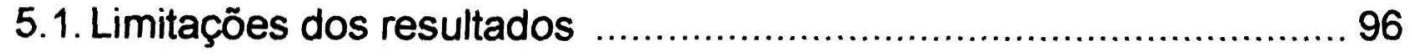

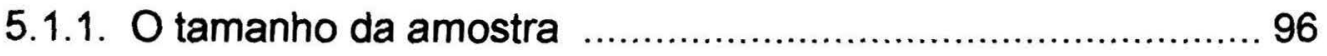

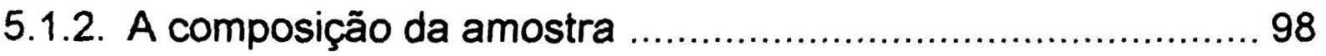

5.2. Questões relacionadas com a validade e confiabilidade ................ 99

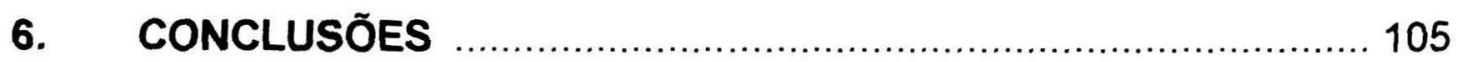

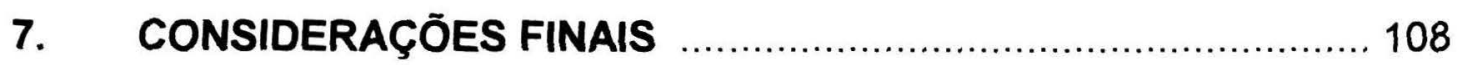

7.1. Em relação à pesquisa ..................................................... 110

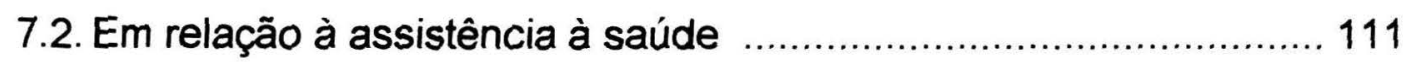

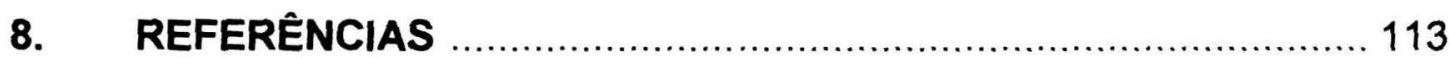

9. BIBLIOGRAFIA COMPLEMENTAR ..................................... 127

ANEXOS:

Anexo 1 - Consentimento informado e esclarecido - grupos focais ...... A-2

Anexo 2 - Concourse of ideas ........................................................

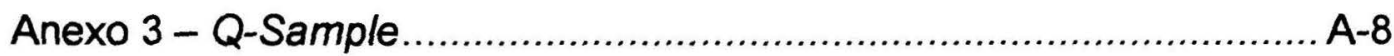

Anexo 4 - Consentimento informado e esclarecido - $Q$...................... A-11

Anexo 5 - Escala invertida....................................................... A-12

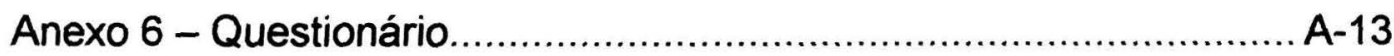

Anexo 7 - Perfil das adolescentes entrevistadas ................................ A-14

Anexo 8 - Perfil das adolescentes por unidade de saúde ................... A-20

Anexo 9 - Análise fatorial (PQMethod) .......................................... A-21

GLOSSÁRIO 
INTRODUÇÃO 


\section{INTRODUÇÃO:}

No discurso da Saúde Pública em geral, gravidez e maternidade na adolescência são consideradas eventos de risco para a morbimortalidade materna e infantil e importantes problemas de saúde. As intervençōes educativas propostas baseiam-se, em sua maior parte, na premissa de que a maternidade na adolescência é não desejada, não planejada e não intencional.

As evidências sugerem que, em idade cada vez mais jovem, mais adolescentes são mães. Os fatores envolvidos nas causas e nas conseqüências deste fenômeno e a eficácia das medidas de prevenção e controle são temas ainda sujeitos a controvérsias. Estas controvérsias podem ser devidas a questões basicamente metodológicas ou a diferenças mais profundas, de origem epistemológica, na abordagem de tema tão complexo.

A maior parte dos estudos sobre gravidez e maternidade na adolescência baseia-se no paradigma biomédico. Em busca da objetividade, estes estudos isolam o fenômeno em estudo do seu contexto e testam hipóteses a partir de teorias preestabelecidas. Tentam definir e entender um adolescente universal e atemporal. São poucos os estudos que seguem o paradigma qualitativo, em que a experiência da gravidez e maternidade na adolescência é entendida a partir da vivência da própria adolescente, e não é considerada homogênea nem linear, mas uma expressão circunstancial única, em tempo 
e espaço.

Pouco ainda se sabe sobre as circunstâncias que envolvem esta experiência de vida, e um melhor entendimento a respeito dos aspectos subjetivos da vivência da maternidade na adolescência é ainda necessário.

\subsection{REVISÃo DA LITERATURA:}

Para melhor abordar o tema da maternidade na adolescência é necessário entender a adolescência e a maternidade. Procedeu-se assim a uma revisão da literatura, com busca bibliográfica nas bases de dados MEDLINE (1966 a 2000), LILACS (34a edição ) e POPLINE (até dezembro de 1998), utilizandose os descritores adolescência e gravidez na adolescência, além de livros e documentos básicos sobre o tema. Nesta revisão da literatura, procuramos questionar algumas conclusões e apontar contradições dentre os resultados dos estudos selecionados.

\subsubsection{Adolescência e adolescentes - definiçóes:}

Todas as culturas reconhecem e marcam a transição da infância para a idade adulta, mas a sociogênese da adolescência é, em termos históricos, um acontecimento relativamente recente, que teve lugar a partir do século XVIII com a Revolução Industrial. Em periodos anteriores da civilização ocidental, já na infância o individuo era preparado para enfrentar as responsabilidades e tarefas da idade adulta, sem um periodo intermediário definido (ARIĖS 1981; CAVALCANTI 1988). 
Na sociedade européia, o conceito de adolescência passou a existir no fim do século XIX, sendo a escola e o exército seus elementos concretos de formação. Já nos paises em desenvolvimento, e em particular no Brasil, o processo de constituição da adolescência foi ainda mais recente e diferente daquele ocorrido nos países desenvolvidos, em função das características de sua formação social, de base aristocrata rural e escravocrata (REIS e ZIONI 1993).

No Brasil do século XIX, os meninos de 10 a 12 anos de idade, tanto os filhos de senhores como os escravos, saíam da infância e entravam no mundo dos adultos através do trabalho. Já as meninas, brancas livres e escravas, entravam diretamente no mundo adulto através da vida sexual e da reprodução biológica. As primeiras casavam-se logo após a primeira comunhão, aos 12 ou 13 anos de idade, e às escravas, geradoras potenciais de novos escravos, era favorecida uma vida sexual precoce e promíscua (FREYRE 1966).

No século XX, e sobretudo após a Segunda Guerra Mundial, a civilização ocidental moderna sofre intensas transformações sociais, econômicas e culturais, e a adolescência passa a constituir objeto privilegiado de estudos e programas de intervenção, particularmente pela área da saúde (REIS e ZIONI 1993).

Em 1974, na Reunião sobre a Gravidez e o Aborto na Adolescência, a Organização Mundial da Saúde (OMS) define adolescência como etapa da vida caracterizada por: progressão a partir do aparecimento de caracteres 
sexuais secundários até a maturidade sexual e reprodutiva; desenvolvimento de processos mentais e da identidade adulta; transição de total dependência sócio-econômica para uma relativa independēncia (WHO 1975).

Assim, segundo a OMS, a adolescência tem seu início objetivamente marcado pela puberdade, mas não tem seu término claramente definido. Este é caracterizado por múltiplos marcadores, que definem a entrada na vida adulta. $\mathrm{A}$ idade de início da puberdade vem diminuindo progressivamente (cerca de 10 meses para cada geração no século $X X$ ), possivelmente em decorrência de melhores condições de saúde e nutrição. Em geral, as meninas entram na puberdade entre 8 e 13 anos e os meninos entre 9 e 14 anos (WINTER 1982). As mudanças físicas características que se iniciam na puberdade ocorrem com uma intensidade e aceleração somente comparáveis às ocorridas na vida pré-natal e no primeiro semestre de vida pós-natal. Estas alterações se dão em geral ao longo de um período de cinco anos, com uma amplitude de variação de duração que se estende dos 18 meses aos seis anos (TANNER 1962). Assim como o desenvolvimento biológico, a maturidade emocional e o desenvolvimento cognitivo variam muito entre jovens da mesma idade, e, em geral, a maturidade física é alcançada antes da maturidade psicológica ou social (COLLI e DELUQQUI 1978).

Embora tente contemplar as diversas dimensōes envolvidas nesta etapa da vida do individuo (biofisiológicas, psicológicas e econômicas), a OMS (WHO 1975) utiliza o critério cronológico para considerar como categoria 
adolescente a população compreendida entre 10 e 19 anos, subdividida em adolescentes menores (os de 10 a 14 anos) e adolescentes maiores (os de 15 a 19 anos). Este critério é o mais utilizado na literatura biomédica.

Do ponto de vista sócio-cultural, a adolescência corresponde ao periodo da vida do individuo em que a sociedade ainda não the atribui o status de adulto, nem o considera mais criança. O término da adolescência não poderia então ser definido somente em termos biológicos ou psicológicos, já que os diferentes grupos sociais estabelecem seus próprios critérios para a caracterização do status de adulto, mais freqüentemente em termos de tradição social do que de maturidade biológica ou psicológica (BECKER 1985). Observa-se que o conceito de adolescência é mais nítido na população urbana do que na população rural e bem mais caracterizado e longo quanto maior for o privilégio da classe social a que pertence (CAVALCANTI 1988).

Na visão psicológica, a adolescência é definida como um período de instabilidade e de crise de identidade, precipitada pela experiência de três lutos fundamentais: o luto pela perda do corpo infantil, o luto pela perda do papel e da identidade infantis e o luto pela perda dos pais da infância. Estas crises, beirando o patológico, caracterizam a "sindrome do adolescente normal", que se compõe dos seguintes elementos: a busca de si mesmo e de sua identidade, tendência grupal, necessidade de fantasiar e intelectualizar, crises religiosas, deslocamento temporal, evolução sexual que vai desde o auto-erotismo até a heterossexualidade genital, atividade 
sexual reivindicatória, contradições sucessivas em diversas manifestações de conduta, separação progressiva dos pais e constantes flutuaçōes de humor e de estado de ânimo (KNOBEL 1981).

Embora amplamente aceita pela área da saúde e hegemônica no discurso da Saúde Pública, a noção de universalidade e atemporalidade do fenômeno da adolescência (e a ideologia positivista que a sustenta) vem sendo denunciada, questionada e criticada por alguns segmentos da Saúde Pública (AYRES 1993; REIS e ZIONI 1993; CASTRO MOURA 1996; PERES e ROSENBURG 1998). Sob a ótica das Ciências Sociais, ao mesmo tempo em que se trata de uma fase, dentro de todo um processo evolutivo do ser humano, a adolescência também deve ser considerada como uma expressão circunstancial de natureza geográfica e sociocultural (KNOBEL e col. 1981). Assim, para o adolescente, a experiência da adolescência não pode ter um sentido único, homogêneo ou linear, pois que é dependente das condições materiais/objetivas e subjetivas de existência de sujeitos reais (PERES e ROSENBURG 1998).

Em sintese, a única definição universalmente aceita de adolescência parece ser aquela em que, não mais considerado ou considerando-se uma criança, o jovem ainda não é considerado nem se considera um adulto. Este processo de transição manifesta-se, então, por mudanças físicas, psiquicas e sociais que determinam novas características da sexualidade do individuo e tem a ver com seu comportamento reprodutivo. Este comportamento tem expressōes diferentes de cultura para cultura, de país para país, nas áreas 
urbanas ou rurais e nas diferentes camadas sociais (MORA 1988).

\subsubsection{Magnitude do fenomeno:}

Um quinto da população mundial é composto por jovens de 10 a 19 anos de idade, totalizando mais de um bilhão de individuos. Em termos absolutos e relativos, a maior parte desses jovens concentra-se nos paises em desenvolvimento (Tabela 1)

Tabela 1 - Distribuição da população estimada (em milhões) segundo idade, no mundo e em localidades selecionadas, 1995 e 1996.

\begin{tabular}{c|ccc}
\hline \multirow{2}{*}{ Localidades } & \multicolumn{3}{|c}{ População } \\
& 10 a 19 anos & Total \\
\hline Mundo & 1073 & 19 & 5716 \\
Países desenvolvidos & 160 & 14 & 1167 \\
Países em desenvolvimento & 913 & 20 & 4550 \\
América Latina/Caribe & 101 & 21 & 482 \\
Brasil & 34 & 22 & 153 \\
\hline
\end{tabular}

Fonte: United Nations (1994) citado por The Johns Hopkins University (1995, p. 4), e IBGE (1996) citado por Ministério da Saúde (1997).

No Brasil, para 2001, estima-se que cerca de $21,7 \%$ da população terá entre 10 e 19 anos de idade: $11,1 \%$ entre 10 e 14 anos e $10,6 \%$ entre 15 e 19 anos, correspondendo respectivamente a cerca de 18,7 milhões e 17,8 milhões de jovens (IBGE 2000). 


\subsubsection{Sexualidade na adolescência:}

Na maioria dos países industrializados e em muitos paises em desenvolvimento, a proibição do ato sexual extraconjugal entre adolescentes é um valor tradicional. A não ser em áreas em que o casamento precoce era comum, supunha-se que os adolescentes se abstivessem de relações sexuais e estabeleceram-se mecanismos culturais para estimular a castidade feminina. Nas últimas décadas, em muitas sociedades, a atividade sexual na adolescência tem sido tolerada. No entanto, esta atividade é submetida a restrições sociais ou culturais a fim de reduzir o risco de gravidez inesperada (THE JOHNS HOPKINS UNIVERSITY 1976).

Estudos realizados em vários paises revelam um aumento na incidência das relações sexuais entre adolescentes. Os fatores que estariam envolvidos na manutenção desta tendência seriam: a menarca mais precoce, o casamento mais tardio, a urbanização e o estilo de vida a ela associado, proporcionando maiores oportunidades de relacionamento sexual e redução da eficácia de restrições sociais tradicionais (THE JOHNS HOPKINS UNIVERSITY 1985).

Se os adolescentes de hoje têm relaçöes sexuais em idade mais precoce ou não que as gerações anteriores é ainda sujeito a controvérsias. Em carta de 1887, Moritz Lamberg relatava em relação à mulher no Rio de Janeiro:

"A rapariga de classes mais baixas do povo, que só em casos raríssimos aprende a ler e a escrever, cresce em absoluta liberdade e é abandonada completamente aos seus instintos 
naturais, pelos quais se deixa guiar... Segundo estatística no Estado do Rio de Janeiro, que se acha em meu poder, no ano de 1893, houve 24 casamentos de raparigas de onze anos e 32 de rapazes de 14..."(LEITE 1993. p.87).

Inquérito populacional realizado em diversos países no fim dos anos 80 e na década de 90 sugere que, dentre as mulheres brasileiras pesquisadas, a mediana da idade da primeira relação sexual vem aumentando (JOHNS HOPKINS UNIVERSITY 1995). O que parece dar maior visibilidade à atividade sexual dos adolescentes nos dias de hoje é o fato de que ela, independentemente de sua idade de início, ocorre antes do casamento.

\subsubsection{Fecundidade na adolescência:}

Dentro do tema de saúde do adolescente, os aspectos relacionados com a reprodução vêm, nas últimas décadas, despertando o interesse particular de instituições oficiais e profissionais de saúde. A literatura a respeito da gravidez na adolescência vem aumentando nos últimos anos, e o tema tem ocupado espaço privilegiado na mídia.

\section{Magnitude:}

Dados demográficos indicam que, em muitas nações industrializadas e em desenvolvimento, os partos de mulheres de menos de 20 anos representam crescente proporção de todos os nascimentos (THE JOHNS HOPKINS UNIVERSITY 1976). 
As estatísticas nacionais revelam que, nos ültimos anos, o número absoluto e relativo de gestações em adolescentes vem aumentando, especialmente no grupo de 10 a 14 anos. No periodo de 1981 a 1996 , enquanto para todas as outras faixas de idade a taxa especifica de fecundidade apresentou variaçāo anual negativa, para os grupos etários de 10 a 14 anos e de 15 a 19 anos observou-se variação anual de $+12,7$ e $+0,3$ respectivamente (Tabela 2).

Tabela 2 - Evolução das taxas especificas de fecundidade por idade. Brasil: $1981-1986$ e 1991-1996

\begin{tabular}{c|ccc}
\hline \multirow{2}{*}{$\begin{array}{c}\text { Faixa } \\
\text { Etária }\end{array}$} & \multicolumn{3}{|c}{$\begin{array}{c}\text { Taxas especificas de fecundidade } \\
\text { (nascimentos / }\end{array}$} \\
\cline { 2 - 4 } & $1981-1986$ & $1991-1996$ & mulheres-ano) \\
\hline $10-14$ & 6,0 & 13,6 & Variação anual (\%) \\
$15-19$ & 92,8 & 95,3 & $+12,7$ \\
$20-24$ & 191,2 & 159,4 & $+0,3$ \\
$25-29$ & 184,6 & 124,3 & $-1,7$ \\
$30-34$ & 127,5 & 78,2 & $-3,3$ \\
$35-39$ & 84,3 & 41,9 & $-3,9$ \\
$40-44$ & $(26,8)$ & 13,8 & $-5,0$ \\
$45-49$ & - & $(1,7)$ & $-4,8$ \\
\hline TOTAL & 3,6 & 2,6 & - \\
\hline
\end{tabular}

Fonte: Monteiro CA e col. 1997.

Nota: Estimativas entre parênteses estão truncadas

Em 1994, 19,8\% dos 2,5 milhöes de crianças nascidas vivas em nosso pais eram filhos de adolescentes, $0,7 \%$ de jovens de 10 a 14 anos e $19,1 \%$ de 
adolescentes de 15 a 19 anos (MINISTÉRIO DA SAÚDE DO BRASIL 1994). Já em $1998,23,2 \%$ do total de 3,1 milhões de partos registrados no Sistema Único de Saúde (SUS) foram de jovens de 10 a 19 anos, dos quais $0,9 \%$ correspondiam a jovens de 10 a 14 anos e $22,3 \%$ a adolescentes de 15 a 19 anos. Em números absolutos, 27205 crianças eram filhos de adolescentes com idade entre 10 e 14 anos (MINISTÉRIO DA SAÚDE DO BRASIL 1998).

Estudos isolados realizados em serviços de saúde apontam para o aumento do número de gestações na adolescência (PINTO E SILVA 1982; CASTRO MOURA 1991).

Em paises desenvolvidos e em desenvolvimento, existe uma tendência ao casamento mais tardio, mas a concepção está ocorrendo em idades mais precoces (THE JOHNS HOPKINS UNIVERSITY 1976).

\section{Risco:}

No discurso da Saúde Pública e dos órgãos gestores nacionais e internacionais, a adolescência e, em especial, a gravidez e a maternidade na adolescência constituem situações de vulnerabilidade a riscos biológicos e psicossociais (SIQUEIRA e TANAKA 1988; REIS 1993; GROSSMAN 1995; GROSSMAN e CARDOSO 1997).

Grande parte do conhecimento atual sobre a adolescência e o adolescente se baseia nos resultados de trabalhos científicos que utilizam o método epidemiológico e tem o conceitual crono-biomédico como marco teórico, ou seja, revelam o predomínio de uma matriz biologicista e cronológica na 
formulação ou adoção de conceitos e práticas (GROSSMAN 1993; CASTRO MOURA 1996; PERES E ROSENBURGO 1998).

A fim de melhor conhecer o objeto de estudo, estas investigações, de um modo geral, têm por objetivos:

- descrever o perfil das adolescentes grávidas e seu filho em suas diversas dimensões;

- identificar fatores de risco para: a gravidez na adolescência; a morbimortalidade materna; as repetidas gestações na adolescência; e a morbimortalidade perinatal e infantil;

- avaliar programas de intervenção.

Alguns resultados mostram-se conflitantes:

\section{A) Quanto ao perfil das adolescentes grávidas:}

Estudos realizados em nosso meio descrevem a adolescente grávida como oriunda de um contexto de desvantagem sócio-econômica, caracterizado por menor renda familiar e menor escolaridade (MONTEIRO e col. 1994).

A sexarca e a gestação sucederam a menarca em intervalo de dois e três anos respectivamente (Cunha e col. citado por CUNHA e col. 1998, p. 45) e, em grande parte dos casos, o abandono escolar precedeu a gravidez (MARQUES e EBRAHIM 1991).

Entrevistas com adolescentes puérperas mostraram que a variável idade se associava positivamente com o conhecimento de métodos anticoncepcionais 
(SCHOR e LOPEZ 1990).

\section{B) Quanto ao risco de morbimortalidade (biológico):}

Em 1922, Harris, citado por SISMONDI e col. (1984, p. 41), afirmava que "do ponto de vista puramente obstétrico, 16 anos ou menos constituem a idade ideal para trazer ao mundo o primeiro filho".

Estudos posteriores associam a gravidez na adolescência a: assistência prénatal deficiente, maior incidência de patologias durante a gestação, maior proporção de partos operatórios e maior número de intercorrências intraparto, principalmente hemorragia e toxemia. Durante o período puerperal, as adolescentes estariam mais sujeitas a anemia pós-parto, toxemia e infecção do que gestantes adultas (ALEGRIA e col. 1989). A intervenção de programas de assistência prè-natal abrangentes teria o potencial de diminuir o risco de muitas destas complicações (O'SULLIVAN e JACOBSEN 1992; SCHOLL e col. 1994; MONTEIRO e col. 1995, ROUQUAYROL e col. 1996).

Outras investigações, ao contrário, sugerem que adolescentes de 16 a 19 anos comparecem, em média, a maior número de consultas no pré-natal e são proporcionalmente menos sujeitas a partos operatórios e a fórceps que gestantes adultas. Apontam também para desfechos menos favoráveis somente no grupo de adolescentes de 12 a 15 anos de idade, que estariam submetidas a maior risco obstétrico do que mulheres acima de 20 anos de idade (AMINI e col. 1996; COSTA 1998). 
Em relação ao concepto, há também divergência nos resultados. Alguns estudos indicam que a idade materna abaixo de 20 anos é fator de risco para baixo peso ao nascer, prematuridade, menor estatura e perímetro cefálico, principalmente a partir da segunda gestação. Filhos de adolescentes apresentariam também maior morbidade e mortalidade perinatal (COOPER e col. 1995; FRASER e col. 1995; HALPERN e col. 1996). Outros estudos não encontram diferenças significativas entre os grupos observados de gestantes adolescentes e adultas (FINKELSTEIN e col. 1982; MERCER e col. 1984; STROBINO e col. 1995; MARIOTONI e BARROS FILHO 1998) e alguns trabalhos identificam a idade materna abaixo de 20 anos como fator protetor para a natimortalidade [idade $\geq 20$ anos: $R C=2,73 ; I C=1,42-5,24]$ (ROUQUAYROL e col. 1996).

A questão central da controvérsia entre pesquisadores é se as conseqüências negativas freqüentemente associadas à gravidezl maternidade na adolescência são devidas à idade da gestante/mãe ou ao contexto social desfavorável em que vive antes mesmo de ficar grávida. Estes resultados conflitantes podem parcialmente ser explicados pela questão metodológica, ou seja, pela possibilidade de viéses de seleção, aferição, confundimento, publicação etc.. As primeiras pesquisas realizadas nas décadas de 60 a 80 documentaram desfechos desfavoráveis da gravidez na adolescência em âmbito biológico, social e econômico. Estes estudos, em grande parte de desenho descritivo, consistiam basicamente de análise de uma ou duas variáveis, sem o controle de possiveis variáveis de 
confundimento. Estudos posteriores fizeram uso de modelos estatísticos mais sofisticados e tentaram controlar o efeito de variáveis não mensuradas. Após o controle de fatores sócio-econômicos e ambientais, alguns resultados sugerem maior risco de morbimortalidade perinatal para o filho de adolescentes com idade abaixo de 15 anos, quando comparado com o concepto de mães de 18 a 29 anos (AOR para prematuridade idiopática = $1,74 ; \mathrm{IC}=1,07-2,84)$, particularmente na presença de baixa idade ginecológica $(A O R=2,64 ; \mathrm{IC}=1,19-3,89)$ (SCHOLL e col. 1997).

Com base nestas informaçōes, a Saúde Pública assume a gravidez I maternidade na adolescência como uma questão social, a partir da perspectiva do risco

\section{C) Quanto ao risco social, psicológico e de desenvolvimento:}

Não há tampouco consenso entre os estudiosos da área a respeito das conseqüências adversas da maternidade durante a adolescência em relação aos aspectos psicológicos e sociais. Algumas evidèncias indicam que a adolescente grávida está mais sujeita ao abandono/fracasso escolar, ao maior número de gestações não desejadas, ao menor intervalo entre gestaçōes e ao maior risco de pobreza do que a gestante adulta (MOORE e WAITE 1977; TETI e LAMB 1989). Outros autores, entretanto, argumentam que as conseqüências negativas sob o ponto de vista sócio-econômico e psicológico têm sido hiperestimadas (NORD e col. 1992).

Durante a gravidez e o puerpério, a adolescente estaria também mais sujeita 
a estresse e depressão (REIS 1989; BARNET e col. 1996). Neste aspecto, o apoio familiar, especialmente da mãe da adolescente ou do pai da criança, é fundamental, uma vez que parece estar inversamente associado à presença e à intensidade dos sintomas depressivos durante a gravidez e após o parto (SCHILMOELLER e col. 1991; BARNET e col. 1996). Outros estudos descreveram atributos positivos da experiência da maternidade para algumas mães adolescentes, em termos de auto-estima, maturidade e projeto de vida (BUCHHOLZ e GOL 1986; THERIOT e col. 1991; ARENSON 1994; DOMINGUES 1998). Da mesma forma, algumas adolescentes com personalidade pessimista mostraram-se menos deprimidas durante a gravidez (WAGNER e col. 1998).

Alguns estudos indicam que o filho da adolescente estaria mais sujeito a maus-tratos e a problemas cognitivos e distúrbios de comportamento, que viriam a se manifestar na idade escolar (MOORE 1986; HASKETT e col. 1994). Outras pesquisas indicam que mães adolescentes não estimulam seus filhos adequadamente, têm expectativas inadequadas em relação ao desenvolvimento infantil, são menos tolerantes, mostram menos empatia em relação às necessidades da criança. Tendem também a ser mais rígidas na educação de seus filhos, apresentando uma comunicação verbal mais negativa quando comparadas com mães adultas (LARSEN e JUHASZ 1985; MCANARNEY e col. 1986; REIS e HERZ 1987; REIS 1989; BARANOWSKI e col. 1990; EAST e col. 1994; CAMP 1995; PANZARINE e col. 1995). Outras investigaçōes sugerem que, apesar de mães adolescentes e mães adultas 
interagirem de forma diferente com seus filhos, os filhos de adolescentes não estariam submetidos a risco de menor desenvolvimento intelectual (ELSTER e col. 1983) e, a longo prazo, teriam um desenvolvimento físico e mental adequado (ROTHENBERG e VARGA 1981; WOLKIND e KRUK 1985). As dificuldades econômicas e estruturais explicariam mais uma vez o maior risco de problemas de comportamento em filhos de adolescentes (NORD e col. 1992).

Embora as relações entre a maternidade na adolescência e as dificuldades sócio-econômicas ainda não sejam totalmente compreendidas, estas poderiam ser parcialmente devidas a diferenças prévias entre a jovem que fica grávida durante a adolescência e as outras adolescentes que não ficaram grávidas (NORD e col. 1992).

\section{D) Quanto ao impacto das intervenções educativas:}

A maior parte dos estudos sugere que a gravidez na adolescência é geralmente não desejada, não planejada e não intencional, produto da falta de informação (THE JOHNS HOPKINS UNIVERSITY 1995; MONTEIRO e col. 1998). Assim, muitos programas estão voltados para a educação sexual, com ênfase na prevenção de gravidez e de doenças sexualmente transmissiveis (ROSENBERG 1998; MEDRADO e LYRA 1999). No entanto, alguns estudos sugerem que, embora possam ser muito eficazes em aumentar o conhecimento de adolescentes sobre concepção e contracepção, muitos programas de educação sexual têm menor impacto no comportamento sexual dessas adolescentes (Kirby 1984, citado por HAYES 
1987, p. 109). Pesquisas realizadas com jovens com vida sexual indicam que alguns adolescentes se colocam intencionalmente em situação de risco para gravidez (SCOTT 1983; STEVENS-SIMON e col. 1996). Existe falta de conhecimento, mas também observa-se uma grande lacuna entre o conhecimento e a utilização de métodos anticoncepcionais (SCHOR e LOPEZ 1990).

$A$ baixa freqüência do uso de preservativos entre os jovens não se daria por falta de informação, mas refletiria um desejo de engravidar. A busca da maternidade poderia ser interpretada como uma estratégia adaptativa de jovens submetidos a dificuldades econômicas e sociais extremas e seria aí que estariam a fonte e a solução do problema (NORD e col. 1992).

\subsubsection{A maternidade na adolescência:}

Assim como os estudos sobre a adolescência, a maior parte das pesquisas sobre a maternidade em geral e sobre a maternidade na adolescência baseia-se no paradigma biomédico. No entanto, na abordagem desta última temática, o enfoque qualitativo é utilizado com maior freqüência.

Assumindo que a maternidade é biológica, instintiva e naturalmente gratificante, estas investigações são primariamente dirigidas para a descrição dos processos físicos e psicológicos característicos desta etapa da vida da mulher. A pesquisa social, no entanto, vem questionando estas premissas e sustenta a hipótese de que o desejo e a capacidade de cuidar de crianças são, em grande parte, socialmente criados. As evidências 
sugerem que a maternidade è uma experiència dificil para muitas mulheres, e o estresse psicológico associado com a maternidade parece não ser um problema transitório, localizado na crise do nascimento. Vários estudos têm demonstrado altos niveis de estresse após o parto (BOULTON 1983; ZUCKERMAN E COL. 1987; BARNET e col. 1996).

Segundo MERCER (1980), tanto a adolescência quanto a maternidade são descritas como crises de maturidade, caracterizadas por um desequilibrio interno e associadas com o crescimento do individuo. A transição para a maternidade seria um processo de desenvolvimento que também envolve a transição para a vida adulta (MERCER 1985). Para o desempenho adequado do papel de mãe seriam necessárias: maturidade, experiências prévias em desempenhar papéis, habilidades cognitivas e empáticas. Uma vez que somente após a idade de 15 anos o raciocínio dedutivo e a habilidade de levantar hipóteses e argumentos para a solução de problemas são desenvolvidos, a adolescente, particularmente a jovem adolescente, apresentaria deficiências que a comprometem a assumir o papel adulto.

Ao mesmo tempo, comportamentos maternais refletem normas sociais, que são opiniōes comuns a respeito do que mães devem ou não fazer. Estes são aprendidos indiretamente na infância ou mais diretamente durante a fase antecipatória da gravidez. O modelo formal inicia com o nascimento da criança, e, durante este estágio, os comportamentos são muito influenciados pelas expectativas consensuais de terceiros. O estágio informal inicia quando a mãe desenvolve seu estilo próprio. Já no estágio final, a mãe 
sente a harmonia entre o "eu" e o papel de mãe, com a aceitação do seu comportamento maternal pelos outros. Este processo tem a duração aproximada de 3 a 10 meses, e, por volta de um ano, a mulher já desenvolve plenamente seu papel de mãe (MERCER 1985).

Com o objetivo de estudar o desenvolvimento do papel de mãe em adolescentes, MERCER (1980) entrevistou 12 mães de 14 a 19 anos. Os sentimentos quanto à maternidade eram dúbios: privações e perdas, recompensas e gratificações; preocupações quanto às mudanças da aparência e da funçăo corporais; e desejo e recusa em considerar as necessidades da criança antes das suas próprias necessidades. $\mathrm{O}$ apoio da familia - particularmente do pai da criança e da avó da criança - foi identificado como fator facilitador para a adaptação ao papel maternal. As jovens mães demonstravam interesse e orgulho em relação ao desempenho psicomotor da criança, e os comportamentos considerados inadequados eram, em sua maioria, caracteristicos do processo normal do desenvolvimento infantil. A falta de resposta às solicitaçōes da criança não era reconhecida como tal, refletindo pouco conhecimento ou falta de habilidade em reconhecer as necessidades da criança. Foram também identificados quatro períodos críticos no primeiro ano de vida do bebê, em termos de hostilidade por parte da mãe:

a) os primeiros dias após o parto - a mãe não se sente mãe;

b) entre a $2^{\circ}$ e a $4^{\circ}$ semana de vida - quando o maior impacto do papel 
materno atinge a adolescente; maior percepção de perdas do que de ganhos; grande demanda de tempo e energia em função dos problemas e demandas do bebê; é o periodo em que as mães apresentaram maior grau de hostilidade;

c) três a quatro meses - o bebê reconhece a mãe e interage de forma mais ativa; a mãe torna-se consciente do seu apego ou desapego; as recompensas são maiores do que as perdas sentidas;

d) seis a nove meses - o bebê distingue a mãe das outras pessoas e esta tende a expressar sentimentos de competência e prazer com a maternidade.

Em estudo posterior com grupos de mães de várias idades, foram identificadas outras demandas e dificuldades especificas em diferentes períodos do primeiro ano de vida. O padrão de problemas foi o mesmo para todas as idades. As principais dificuldades que as mães relataram eram: falta de tempo pessoal (para comer, tomar banho, conversar com outros etc.) e falta de tempo para dormir, particularmente por volta do primeiro mês de vida; o excesso de responsabilidade e a falta de liberdade foram dificuldades relatadas ao longo de todo o primeiro ano de vida do bebê; a sensação de incompetência e incapacidade em desenvolver o papel de mãe, menor gratificação e menor número de sentimentos positivos em relação à criança foram problemas relatados a partir do $8^{\circ}$ mês de vida, em função do comportamento mais independente da criança (engatinhar, mexer em tudo, 
dentição, acidentes etc.). As adolescentes relataram diminuição do apoio de pessoas em sua rede social, menor apoio emocional e menor gratificação com o papel de mãe por volta de um ano (MERCER 1985).

Estudos que partem da própria perspectiva da mulher quanto à experiência da maternidade identificaram duas categorias principais de sentimentos: a resposta imediata, ou seja, o prazer e a alegria, a frustração e irritação que as mulheres sentem em suas atividades cotidianas com seu bebê; e o senso de significado e propósito que as mulheres sentem enquanto mulheres e mães (BOULTON 1983). Estudando a gravidez em seis adolescentes menores de 15 anos, MACKLIN (1992) identificou duas outras categorias, que descrevem como os adolescentes vivenciam a maternidade: a primeira representou os aspectos dificeis de ser jovem e mãe (reação da familia e dos amigos, perda de vida social, perda de atividades, dificuldades físicas e emocionais, "é muito cedo", "tenho medo" etc.); a segunda revelou um aspecto mais positivo (apoio dos outros, coisas que você pode fazer com uma criança etc.).

Em outra investigação com mães adolescentes, também utilizando metodologia qualitativa, foram identificadas diferenças importantes entre as mães adolescentes, suas necessidades e seus sistemas de apoio. Em função dessas diferenças, foi enfatizada a necessidade de individualizar a abordagem, sugerindo que atividades educativas estruturadas e rotineiras voltadas para o desenvolvimento de habilidades parentais e para o conhecimento das etapas do desenvolvimento da criança nem sempre são 
necessárias ou suficientes (LANDY e col. 1984).

\subsubsection{Programas de saúde do adolescente:}

No início do século $X X$, a gravidez na adolescência era considerada um acontecimento normal para os padrões da época (HOLLINGSWORTH e FELLICE 1986) Já no senso comum atual, a gravidez e a maternidade na adolescência são considerados eventos dramáticos, indesejados e indesejáveis, associados com ignorância, desconhecimento, pobreza, doença ("a epidemia", a patologia gravidez dentro da patologia adolescência) e decadência dos valores morais.

"O mundo virou uma grande feira de sexo, com explosão de adultério, divórcio, AIDS e outras doenças sexualmente transmissiveis, aborto, prostituição, pornografia, estupro, perversão e gravidez na adolescência (ênfase nossa) ....". (LINS 1999).

Apesar de o conhecimento a respeito da adolescência e dos adolescentes (assim como a respeito da gravidez e maternidade na adolescência e das adolescentes grávidas e mães) ser ainda restrito e fragmentado, a comunidade cientifica em geral e os organismos internacionais compartilham da mesma visão negativa da sociedade em geral.

Documentos publicados pela OMS (WHO 1975, OMS 1989) e pela Organização Panamericana de Saúde - OPAS (OPAS 1987, 1990) ao longo das três últimas décadas traduzem um discurso de atenção integral à saúde do adolescente enraizado no paradigma biológico e centrado do conceito de 
risco. Em consonância com a proposta social da OMS e da OPAS, em 1989 o Ministério da Saúde do Brasil define as diretrizes, objetivos e estratégias para a implementação do Programa Saúde do Adolescente - PROSAD (MINISTÉRIO DA SAÚDE DO BRASIL 1989, 1993). Tendo como objetivo nortear a saúde pública através de propostas oficiais, normalizadoras da atenção à saúde de jovens de 10 a 19 anos e dirigidas a profissionais no nivel primário de atenção à saúde, o PROSAD se constitui enquanto um discurso político (GROSSMAN 1995). Fragmentando sua proposta de atenção integral, O PROSAD define áreas consideradas prioritárias de atuação: acompanhamento do crescimento e desenvolvimento, sexualidade, saúde bucal, saúde mental, saúde reprodutiva, saúde do escolar adolescente, prevenção de acidentes, trabalho, cultura, esporte e lazer (MINISTÉRIO DA SAÚDE DO BRASIL 1989).

Assim, a gravidez na adolescência é abordada pelas instituiçōes oficiais como problema de saúde pública, e as intervenções preconizadas se baseiam no enfoque de risco, em que a adolescência é fator de risco e a adolescente faz parte de um grupo de risco.

Merece destaque a ênfase dada pelo PROSAD à sexualidade e à saúde reprodutiva, com propostas de normas e procedimentos voltados para o apoio à adolescente e à adolescente gestante e para a pouca (senão ausente) atenção à mãe adolescente.

BRANCO (1997) critica o rótulo de "problema", e considera que esta visão reducionista da gravidez na adolescência gera posturas rigidas e 
preconceituosas entre os próprios profissionais de saủde, o que contribui para expor essas adolescentes a riscos adicionais, hostilizá-las nos serviços e desvirtuar os objetivos das açōes educativas.

Segundo CUNHA e MONTEIRO (1998), a adolescente está no meio do processo de capacitação profissional, e é desejável que ela complete sua formação, integre o mercado de trabalho e, só a partir desse momento, colabore gerando a prole que irá garantir a continuidade de seu grupo social.

Em consonância com esta perspectiva, a Sociedade Brasileira de Pediatria, através do Comitê de Adolescência, em convênio com o Ministério da Saúde, elabora em 2001 o Guia de Adolescentes, material de educação continuada dirigido a pediatras. No capítulo de Atendimento da Adolescente Grávida (pág. 52), o guia propõe, dentre outras atividades, que os serviços de saúde resgatem

“... sempre a auto-estima dessas adolescentes, na tentativa de que haja retomada do projeto de vida (volta à escola, ao trabalho, ao lazer);...." (SOCIEDADE BRASILEIRA DE PEDIATRIA 2001).

A gravidez na adolescência, segundo o discurso dos órgãos oficiais e das sociedades cientificas é, então, fruto de problemas emocionais e constitui um empecilho para a adolescente cumprir sua função social. De acordo com FURTADO (1979), porque impediria a adolescente de se lançar no mercado de trabalho e evoluir na profissão, comprometendo a estrutura financeira da familia, a gravidez na adolescência vem constituindo questão prioritária para 
o Estado nestes últimos anos.

\subsection{CONSENSO E CONTROVÉRSIAS:}

Alguns resultados conflitantes dos estudos acima mencionados podem ser devidos a questões metodológicas (presença de viéses). No entanto, as controvérsias acerca da gravidez/maternidade na adolescência também se fundamentam na adoção pelos pesquisadores de diferentes paradigmas de referência. Em busca da objetividade, os estudos baseados no paradigma biomédico isolam o fenômeno em estudo do seu contexto e testam hipóteses a partir de teorias preestabelecidas. Tentam definir e entender um adolescente universal e atemporal. Mas os adolescentes não constituem um grupo monolítico, e a gravidez/maternidade na adolescência não é uma questão unitária. Para jovens de diferentes idades e circunstâncias de vida, o significado da gravidez e da maternidade não é o mesmo (HAYES 1987), e os valores, normas e expectativas que influenciam suas atitudes variam imensamente. Suas capacidades de estabelecer metas na vida e avaliar oportunidades e riscos são muito diferentes.

Independentemente do paradigma de referência, algumas tendências emergem dos diversos estudos em relação à gravidez / maternidade na adolescência:

- está aumentando em números absolutos e relativos particularmente entre jovens de 10 a 14 anos;

- é considerada problema de saúde pública; 
- estudos iniciais hiperestimaram as conseqüências negativas da gravidez/maternidade na adolescência;

- as conseqüências sócio-econômicas e educacionais são parcialmente devidas a diferenças preexistentes entre as adolescentes que ficaram grávidas e aquelas que não ficaram grávidas;.

- os programas de saúde pública, normativos e fragmentados estão baseados no enfoque de risco;

- a literatura a respeito de gravidez na adolescência é mais vasta do que sobre a mãe adolescente e seu filho;

- a gravidez e maternidade na adolescência constituem tema ainda polêmico e sujeito a controvérsias;

- apesar do volume de conhecimento acumulado nas últimas década a respeito das conseqüências da gravidez/maternidade na adolescência, ainda pouco se conhece a respeito da experiência da maternidade sob a perspectiva da própria adolescente.

A literatura biomédica nacional é carente em investigações sobre a mãe adolescente e seu filho. Estudos que explorem aspectos subjetivos, tais como opiniões, valores e atitudes de mães adolescentes a respeito da sua vivência da maternidade são particularmente raros. A consulta às bases bibliográficas MEDLINE (1966 a 2000), LILACS (34 edição) e POPLINE (até dezembro de 1998) não identificou trabalhos publicados em língua portuguesa nesta área e com este enfoque. No entanto, pesquisas com este objetivo são necessárias para ampliar nosso conhecimento a respeito das 
circunstâncias de vida dessas jovens e de seus possiveis cursos de vida, a fim de permitir melhor compreensão das motivaçōes e necessidades de mães adolescentes, possibilitando avaliar não somente a necessidade de intervir, mas quando, onde e como melhor intervir. 


\section{OBJETIVOS}




\section{OBJETIVOS:}

A hipótese que inspira esta pesquisa é que o significado da maternidade não é único para jovens mães adolescentes e que dentre estas adolescentes podem ser identificados diferentes padrões de opiniões e expectativas em relação à vivência da maternidade.

\subsection{PRINCIPAL:}

Este estudo tem por objetivo explorar e desvendar os diferentes padrões de opiniões e vivências da maternidade em jovens mães que ficaram grávidas entre os 10 e os 14 anos de idade, assim como identificar problemas e/ou estratégias encontradas. Através da aplicação da Metodologia Q, pretende contribuir para um melhor entendimento das circunstâncias de vidas destas jovens e de suas atitudes frente à maternidade e, assim, colaborar com subsídios para o planejamento de intervenções na área da Saúde do Adolescente.

\subsection{SECUNDÁRIO:}

Este estudo pretende também introduzir a Metodologia $Q$ no âmbito das ciências da saúde em nosso meio *

\footnotetext{
* Embora não indexado na base LILACS com o descritor $Q$-Sort, foi possivel recuperar um trabalho publicado na Revista de Saúde Pública (Balduino MA e Lessa ZL. A Técnica Q como instrumento de medida na área da educação em saúde. Rev Saúde Pública 1986; 20(1): 37-61). A análise do texto, entretanto, revela que a técnica $Q$ foi utilizada sem obedecer aos principios metodológicos da Metodologia Q de Stephenson.
} 


\section{MÉTODOS:}

\subsection{NOSSO INTERESSE PELA MetOdologia Q:}

Sou pediatra há 23 anos, com especialização em Saúde Pública. Trabalho em duas instituições de ensino superior no Rio de Janeiro e, em ambas, desempenho atividades voltadas à pesquisa em saúde materno-infantil.

Em 1994, como aluna do Programa Master in Health Professions Education do Department of Medical Education, University of Illinois at Chicago (DMEUIC), EUA, fui apresentada aos princípios, métodos e técnicas que baseiam o uso da Metodologia $Q$ pelo Prof. Dr. Robert Mrtek. Sob sua orientação, e utilizando esta nova abordagem metodológica, desenvolvi como dissertação de mestrado um estudo a respeito das opiniões e expectativas de médicos de família do interior do Estado de Illinois em relação às características de uma revista médica ideal ${ }^{\dagger}$. Os resultados do estudo ampliaram o conhecimento sobre o assunto e apontaram para a necessidade de diferentes estratégias de educação médica continuada.

A Metodologia $Q$ é particularmente útil na abordagem de temas em que há controvérsia e em que a subjetividade desempenha um papel importante. Desta forma, acredito que o uso da Metodologia $Q$ no estudo de alguns aspectos da maternidade na adolescência poderá contribuir para o esclarecimento de muitos aspectos ainda obscuros e conflitantes e levantar

\footnotetext{
"Rural Physicians' Perceptions of Quality in Medical Journals". Anais de "Abstracts" da $34^{\text {th }}$ Annual Research in Medical Education Conference, Washington, DC, EUA, p. 56, 1995

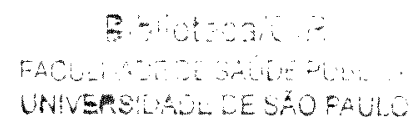


novas hipóteses.

\subsection{A Metodologia Q:}

\subsubsection{Introdução:}

A Metodologia Q foi introduzida por William Stephenson (1902-1989 - PhD em Física pela Universidade de Durham e em Psicologia pela Universidade de Londres) em 1935 (STEPHENSON 1935a, 1935b). É voltada para o estudo sistemático da subjetividade humana, ou seja, "... a comunicação de uma pessoa de seu próprio ponto de vista..." (McKEOWN e THOMAS 1988) e, para tal, utiliza princípios qualitativos e quantitativos de investigação científica. Segundo STEPHENSON (1969), a subjetividade é auto-referente, baseada no padrão interno de referência da pessoa, e a Metodologia $Q$ torna possivel a observação da estrutura e da forma da subjetividade humana, sem a utilização de definições operacionais prévias de parâmetros ou variáveis, mas com uma derivação a posteriori do comportamento subjetivo do individuo (STEPHENSON 1969; McKEOWN e THOMAS 1988). A Metodologia $Q$ pretende desvendar a diversidade subjetiva encontrada entre os individuos.

Apresentada ao mundo científico há mais de 60 anos, a Metodologia $Q$ não pode ser considerada uma estratégia nova ou inovadora. Em 1986, a literatura sobre Q somava mais de 1500 estudos (BROWN 1986). No entanto, é ainda pouco conhecida pela comunidade científica nacional e internacional, e seus princípios metodológicos são muitas vezes 
erroneamente reduzidos aos procedimentos técnicos (técnica $Q$ ou análise fatorial invertida). Para Stephenson, era de fundamental importância fazer uma clara distinção entre a técnica $Q$, o método $Q$ e a Metodologia $Q$ Enquanto sua metodologia envolve principios filosóficos, psicológicos, lógicos e experimentais (STEPHENSON 1953), a técnica Q é um dos procedimentos operacionais (o uso de Q-Sorts, em oposição ao uso, por exemplo, de escalas ou questionários) e o uso de análise fatorial e análise de variância definem o método $Q$ (BROWN 1980).

Inicialmente restrita ao campo da pesquisa comportamental em Psicologia (McKEOWN 1984), nas últimas décadas a Metodologia $Q$ tem sido amplamente utilizada nas ciências sociais e nas mais diversas áreas, tais como: comunicação (STEPHEN 1985). ciências politicas (BROWN 1982: GARGAN e BROWN 1993), saúde (LARSON 1984: DENNIS e GOLDBERG 1996) e educação médica (WIGGER e MRTEK 1994; BARBOSA e col 1998)

Em 1977, o periódico Operant Subjectivity, voltado para a divulgação de artigos relacionados à Metodologia Q, começa a ser publicado com regularidade. Nos anos 90 , com a criação da International Society for the Scientific Study of Subjectivity, Operant Subjecticity é adotado como sua revista oficial. Esta sociedade organiza encontros cientificos anuais desde 1985, com o propósito de discutir as implicações e a aplicabilidade das idéias de Stephenson nas mais diversas áreas. A partir de 1992, um grupo de discussão se desenrola via Internet (endereço para inscrição: 
listserv@listserv.kent.edu), e, em abril de 2001, o website www.qmethod org

é inaugurado. Pacotes estatísticos especificos já foram desenvolvidos, sendo um deles de domínio público: "QMethod Program" (ATKINSON 1992), disponivel para versão PC no seguinte endereço eletrônico:

http://www.rz.unibw-muenchen.de/ p41bsmk/qmethod.

\subsubsection{Referencial teórico:}

Stephenson critica a visão mecanicista e fragmentada da ciência newtoniana, que divide o mundo em duas partes isoladas: o mundo da ciência (objetivo, real) e o mundo da vida (subjetivo). Na sua visão, ao privilegiar os fatos e a objetividade para uma aproximação da realidade, a inferência dedutiva e reducionista de POPPER (1959) desconsidera o fator humano e considera toda e qualquer subjetividade como aleatória e acidental (STEPHENSON 1978). Discorda também da exclusão da subjetividade do individuo na tradição behaviorista, que se caracteriza pelo estudo objetivo do comportamento humano (a partir do ponto de vista externo do observador) (STEPHENSON 1953).

Por suas posições contrárias aos referenciais teóricos dominantes em sua época, Stephenson foi classificado como pós-positivista, pós-behaviorista e contrário à ciência. No entanto, ele próprio classificou sua posição filosófica como "postulatory-dependency", em contraste com o paradigma hipotéticodedutivo, cujos principios norteavam todos os testes psicométricos em uso (testes de medidas de habilidade mental, temperamento, inteligência etc.) 
Ao mesmo tempo em que criticava as limitações do modelo convencional hipotético-dedutivo, Stephenson se alinhava com algumas idéias de Wittgenstein, Schlick e Feigl (STEPHENSON 1953). Por esta razão, muitos o classificaram como positivista.

Segundo Stephenson, a subjetividade no contexto da Metodologia $Q$ não se sustenta na Fenomenologia, uma vez que o que realmente lhe interessa é o que a pessoa tem a dizer, diretamente, sem qualquer inferência do observador. Segundo outros autores, a Metodologia $Q$ se aproxima de algumas tradições baseadas na modelagem de textos, como a hermenêutica, o deconstrutivismo e a análise de discurso, mas introduz procedimentos e medidas diferentes no processo de análise e interpretação (GARGAN e BROWN 1993).

Stephenson assinala as similaridades entre a Metodologia Q e a teoria quântica: ambas utilizam a mesma modelagem matemático-estatistica e, enquanto a teoria quântica refere-se a estados da matéria, $Q$ refere-se a estados de pensamentos - states of mind. Da mesma forma, os fatores da metodologia $Q$ são indeterminantes e não se pode predizer com certeza exatamente como os fatores irão emergir, nem tampouco sua forma ou estrutura (STEPHENSON 1980; BROWN 1986).

Analogias também têm sido referidas entre alguns principios da Metodologia Q e temas da pós-modernidade, tais como: oposição à objetividade da modernidade; ênfase na auto-referência e no discurso, fragmentação, com perda de texto e contexto e ganho de intertextualidade; verdades 
consideradas como questões subjetivas, relativas, indeterminadas e imprevisiveis (GELULA 1997; GROSSWILER 1997)

\subsubsection{Princípios teóricos:}

As seguintes premissas fornecem as bases teóricas da Metodologia $Q$ (STEPHENSON 1978):

- o "eu "subjetivo está no centro de todo o significado e os sentimentos estão na origem da subjetividade;

- medidas objetivas e observações podem, a princípio, ser feitas por qualquer pessoa (ou mecanicamente, por um aparelho); medidas e observações a respeito da subjetividade da própria pessoa só podem ser feitas por ela mesma, a partir de sua própria estrutura interna de referência;

- a subjetividade é comunicada através da linguagem de sentimentos e opiniões, mais do que de fatos;

- os sentimentos se expressam num continuum, e não em categorias;

- se o propósito é captar os sentimentos subjetivos do sujeito, não é apropriado avaliar e comparar os aspectos individuais com as médias de grupos. A estrutura subjacente dos aspectos subjetivos pode, entretanto, ser investigada e esclarecida através do estudo de um grupo de individuos que compartilham pontos de vista em comum, um grupo de cada vez. 


\subsubsection{A Metodologia $Q$ - estratégia privilegiada para o estudo da subjetividade:}

De um modo geral, na literatura biomédica, o estudo de padrões de opiniões, percepções, expectativas, problemas e barreiras é feito através do uso de métodos objetivos, tais como questionários com perguntas fechadas ou escalas.

Nos questionários, o investigador quantitativo parte muitas vezes de definições operacionais prévias, baseadas em categorias preestabelecidas, e busca respostas às perguntas que ele dirige aos sujeitos do estudo. Desta forma, coloca os sujeitos do estudo dentro dos limites da sua própria estrutura conceitual. Os resultados assim obtidos são relatados em percentuais agregados ou em subgrupos arbitrariamente escolhidos, o que freqüentemente mascara a individualidade de cada sujeito. Assim, métodos quantitativos tradicionais, quando aplicados em estudos qualitativos, muitas vezes não conseguem explicar as questões que estão sendo investigadas. 0 investigador só é forçado a exceder os limites da sua estrutura original quando os dados insistentemente se comportam de forma inesperada. Poucas têm sido as tentativas de examinar o mundo a partir de um ponto interno do sujeito (BROWN 1980).

Com o uso de escalas de atitudes, o investigador comportamental pretende medir (indiretamente) determinadas características (traços), que representam atitudes e sentimentos. Os componentes $x$, y e $z$ são declarados propriedades do traço $A$ (p.ex., depressão); as frases $X, Y$ e Z 
são construidas e submetidas a testes de validade e confiabilidade; e a escala é administrada aos sujeitos do estudo. A escala XYZ é a definição operacional de A, ou seja, A é definido operacionalmente por XYZ. Se, por exemplo, o sujeito responde positivamente à escala $X Y Z$, ele é considerado, por definição, possuidor de determinada atitude (BROWN 1980).

Segundo Stephenson, no entanto, a linguagem é por natureza simbólica e auto-referente, e a relação que um individuo tem com suas próprias palavras é totalmente diferente de uma outra pessoa. Para cada pessoa, cada combinação de palavras é capaz de carregar um amplo espectro de significados. Quando o sujeito responde a um item numa escala, o significado que ele dá à sua resposta pode diferir em aspectos importantes do sentido assumido pelo observador (STEPHENSON 1969)

Numa escala, o teste é construido contendo assertivas de ambos os extremos e cada respondente é avaliado através de uma média, criando a falsa impressão de um continuum da esquerda para a direita, enquanto em realidade trata-se de um artefato de técnica, que reflete o método de coleta de dados. Assim, os resultados da análise estatística dos escores de uma escala podem não avançar no conhecimento, uma vez que, quando chamado a interpretar os resultados, o investigador é forçado a retornar à construção original da escala, que foi sobreposta ao comportamento sob estudo. As definições operacionais limitam o comportamento, substituindo o significado do sujeito pelo do investigador, e o pesquisador acaba estudando mais os limites do que o próprio comportamento. O problema é quando mais 
de um ponto de vista ocorre na amostra, especialmente se estes pontos de vista são discordantes. Não há oportunidade de ordenação e tenta-se capturar os sentimentos do respondente, comparando-os com algum padrão. Muitas vezes os dados são apresentados sob a forma de distribuição de freqüências, e, porque algumas ou a maior parte das células têm pequeno número de respondentes, o pesquisador acaba combinando categorias de respostas, desperdiçando informação (BROWN 1980).

No entanto, os principais argumentos contra as definições operacionais são que, muitas vezes, elas sāo desnecessárias e, freqüentemente não fornecem resultados úteis que possam representar avanços no conhecimento. Seria pouco útil fazer uma pergunta a alguém ou submetê-lo a uma escala se uma decisão já foi tomada sobre o significado de sua resposta.

Segundo a Teoria da Comunicação de Stephenson, conversar, discutir e outros comportamentos verbais que se dão no cotidiano social da vida relacionam-se com nossos interesses e situação social. Este tipo de comunicação situa-se na interface subjetiva das circunstâncias que envolvem o indivíduo (como o "eu" sente e vive estas circunstâncias) e não no universo não-subjetivo de fatos exteriores. Desta forma, este tipo de comportamento é subjetivo e operante. Subjetivo porque o ponto de vista de cada pessoa não é certo ou errado; é simplesmente o seu ponto de vista. É operante (e não operacional), porque existe naturalmente num determinado ambiente (STEPHENSON 1969).

Assim, segundo Stephenson, questionários e escalas não seriam os 
métodos mais adequados para o estudo da subjetividade, uma vez que introduzem definições e idéias a priori.

"What is required instead is the respondent's own ideas and patterns of mind, as operants, untouched by the behavioral scientist."

(STEPHENSON 1969).

De acordo com essa teoria, a Metodologia $Q$ é a estratégia de escolha para o estudo da subjetividade.

\subsubsection{O método Q:}

O uso de métodos e técnicas de correlação e análise fatorial no estudo do comportamento humano é produto do avanço na teoria estatística alcançado por Karl Pearson e Charles Spearman no fim do século XIX e início do século XX. A técnica R, ou seja, a aplicação do coeficiente de correlação de Pearson ao estudo de relações entre variáveis (traços ou características), tem sido o método de uso mais predominante.

Em julho de 1935, Sir Godfrey Thompson propõe correlacionar pessoas ao invés de medidas, e sugere o uso da letra " $Q$ " para diferenciar do "R" de Pearson (a serem denominados neste estudo simplesmente $Q$ e R). Ao mesmo tempo, e de forma independente, Stephenson caminha na mesma linha teórica. Havia, entretanto, uma diferença conceitual básica entre os dois pesquisadores fatoriais. Enquanto Thompson buscava diferenças interpessoais, em que cada indivíduo, de forma independente, era testado através de uma bateria de testes, Stephenson buscava diferenças de 
significado "intra-individuais", o que foi aceito com reservas pela comunidade acadêmica de fatorialistas (BROWN 1980).

A distinção entre pessoas e caracteristicas nos métodos $R$ e $Q$ levou muitos estatísticos à conclusão de que o método $Q$ nada mais seria do que a análise fatorial $R$ invertida. A controvérsia $Q-R$ se mantém até os dias atuais, e a maior parte dos livros de estatística e estudos que utilizam a técnica de análise fatorial invertida têm por base as idéias de Thompson e seus sucessores, e não as de Stephenson (BROWN 1980, 1982; McKEOWN e THOMAS 1988).

No método $R$, os casos são registrados nas linhas da matriz e correspondem aos individuos $(a, b, c, \ldots n)$; as variáveis medidas são registradas nas colunas e correspondem às características (ou traços) destes indivíduos ( $A$, $B, C, \ldots N)$ (Tabela 3). A correlação resume as relações entre as variáveis e a análise fatorial revela os grupos de características estatisticamente diferentes. As unidades de medida das variáveis são centralizadas por coluna, ou seja, os escores apresentam a mesma unidade de medida da característica estudada. Os fatores representam grupos de características estatisticamente diferentes, que se relacionam com constructos complexos. 
Tabela 3 - Distribuição de $N$ traços em $n$ pessoas.

\begin{tabular}{c|ccccc}
\hline & \multicolumn{5}{|c}{ Traços } \\
Pessoas & $A$ & $B$ & $C$ & $\ldots$ & $N$ \\
\hline$a$ & ${ }_{a} X_{A}$ & ${ } X_{B}$ & ${ }_{a} X_{C}$ & $\ldots$ & ${ }_{2} X_{N}$ \\
$b$ & ${ }_{b} X_{A}$ & ${ }_{b} X_{B}$ & ${ }_{b} X_{C}$ & $\ldots$ & ${ }_{b} X_{N}$ \\
$c$ & ${ } X_{A}$ & ${ } X_{B}$ & ${ } X_{C}$ & $\ldots$ & ${ } X_{N}$ \\
$:$ & $:$ & $:$ & $\vdots$ & $\ldots$ & $\vdots$ \\
$n$ & ${ }_{n} X_{A}$ & ${ }_{n} X_{B}$ & ${ }_{n} X_{C}$ & $\ldots$ & ${ }_{n} X_{N}$ \\
\hline
\end{tabular}

Fonte: Brown, 1980.

Na método $Q$, as pessoas passam a ser as variáveis em estudo. $\mathrm{Na}$ transposição da matriz, os individuos são representados nas colunas (A, B, C,...N) e características são representadas nas linhas (Tabela 4). Desta forma, os atributos de cada linha apresentam a mesma unidade de medida, e não as colunas. As colunas agora consistem de escores, cuja distribuição estatística não é mais centralizada em volta de uma unidade de medida comum.

Tabela 4 - Distribuição de $N$ pessoas em $n$ traços

\begin{tabular}{c|ccccc}
\hline & \multicolumn{5}{|c}{ Pessoas } \\
Traços & $A$ & $B$ & $C$ & $\ldots$ & $N$ \\
\hline$a$ & ${ }_{a} X_{A}$ & ${ }_{a} X_{B}$ & ${ }_{a} X_{C}$ & $\ldots$ & ${ }_{a} X_{N}$ \\
$b$ & ${ }_{b} X_{A}$ & ${ }_{b} X_{B}$ & ${ }_{b} X_{C}$ & $\ldots$ & ${ }_{b} X_{N}$ \\
$c$ & ${ } X_{A}$ & ${ } X_{B}$ & ${ } X_{C}$ & $\ldots$ & ${ } X_{N}$ \\
$:$ & $\vdots$ & $:$ & $:$ & $\ldots$ & $\vdots$ \\
$n$ & ${ }_{n} X_{A}$ & ${ }_{n} X_{B}$ & ${ }_{n} X_{C}$ & $\ldots$ & ${ }_{n} X_{N}$ \\
\hline
\end{tabular}

Fonte: Adaptado de Brown, 1980. 
No entanto, correlação e análise fatorial assumem no mínimo linearidade, e, nesta situação, não existe qualquer linearidade em cada variável, uma vez que as unidades de medida são diferentes (BROWN 1980). Esta questão metodológica inviabilizou por muitos anos o uso do método $Q$ enquanto mera análise fatorial invertida. Foi Stephenson quem estabeleceu uma fundação psicométrica mais segura ao método de "fatoriar pessoas", propondo uma solução para a questão da unidade de medida:

"All observations in Q-technique are premised on a common unit of measurement, namely, "self-significance". (STEPHENSON 1935b)

As características que compõem a matriz $Q$ estão centralizadas em volta de uma média de significado psicológico, ou seja, "a importância para mim". Assim, frases como $A>B$ ou vice-versa agora passam a ter um significado para propósitos de mensuração, e a premissa de linearidade é satisfeita. As variáveis em estudo (indivíduos) podem ser submetidas a correlação e análise fatorial. Em função deste uso incomum da análise fatorial, o método é também chamado de análise fatorial "por pessoa".

\subsubsection{Etapas para a realização de um estudo $Q$ :}

\section{A. Elaboraçāo do concourse of ideas:"}

A primeira etapa para a realização de um estudo é a elaboração de uma lista ampla, diversa e abrangente de opiniões, sentimentos e idéias relativos ao

\footnotetext{
" As etapas relativas à realização de um estudo Q e à análise fatorial que, na literatura consultada, não encontram tradução para o português foram mantidas em seu original na língua inglesa (em itálico).
} 
tema em estudo, o concourse of ideas (McKEOWN e THOMAS 1988;

BARBOSA e col. 1998).

Segundo Stephenson, o concourse of ideas é a distribuição contínua do fluxo corrente de opiniões e idéias relativas a qualquer assunto que configuram a conversação corriqueira, e cabe à Metodologia $Q$ revelar os vetores do pensamento que estruturam este "concourse" (STEPHENSON 1969).

Esta lista é gerada a partir de: entrevistas, literatura, diários, observação, atividades de grupo para a geração de idéias (grupo focal, grupo nominal, tempestade de idéias, TV, jornais) etc. O concourse of ideas representa a gama de opiniões e sentimentos, ambos positivos e negativos, sobre o assunto em questão. Os itens de um "concourse" não devem ser fatos, mas expressões auto-referentes de sentimentos e opiniões subjetivas a respeito de um assunto, em linguagem natural e corriqueira (McKEOWN e THOMAS 1988; BARBOSA e col. 1998).

\section{B. Seleção do Q-sample:}

A partir da lista, procede-se à seleção de uma amostra representativa, mas não necessariamente exaustiva, de frases (Q-sample). Estas amostras são representações dos contextos de comunicação e devem, assim, representar as principais idéias e opiniões. O número de itens na amostra deve ser suficiente e com a maior variedade possivel de opiniões, a fim de permitir que pessoas com pontos de vista bastante diferentes consigam ordená-los 
sem dificuldades. Esta ordenação permite a "visualização" da subjetividade do indivíduo, e somente será considerada válida se representar adequadamente as opiniões do sujeito sobre o tema em questão. Desta forma, validade em $Q$ está relacionada com o grau de satisfação que o respondente sente em relação à acurácia da representação dos seus sentimentos pela ordenação dos itens (McKEOWN e THOMAS 1988; BARBOSA e col. 1998).

A amostra tipicamente tem entre 20 e 100 sentenças. Embora amostras bem maiores já tenham sido utilizadas, estudos apontam que os resultados, expressos pelo número de fatores ou grupos de atitudes, não se modificam quando a amostra é pequena, desde que represente de forma abrangente as idéias existentes sobre o tema. As amostras $Q$ podem ser selecionadas de duas formas: seleção estruturada e não estruturada. As amostras estruturadas são montadas de forma sistemática, a partir da identificação de categorias de significado, e permitem que hipóteses sejam testadas, com a incorporação de considerações hipotéticas na amostra. Na amostragem não estruturada, os investigadores escolhem o número de itens que abrangem os aspectos conhecidos sobre o assunto e eventualmente acrescentam alguns itens que não apareceram no "concourse". Nesta abordagem, o investigador deve estar alerta à possibilidade de viéses, com a hipo ou hiper representação de alguns componentes. (McKEOWN e THOMAS 1988; BARBOSA e col. 1998) 


\section{Ordenação (Q-Sorting):}

$\mathrm{Na}$ etapa seguinte, é necessário o desenvolvimento de uma métrica para a descrição das opiniões subjetivas dos respondentes em relação às sentenças. Para que o estudo da subjetividade seja possível, é importante considerar a premissa de que, em determinado momento, todo indivíduo tem uma posição definida em relação a um determinado assunto e também de que esta posição pode ser representada pela ordenação dos itens da amostra $Q$. O fato de que opiniões mudam ao longo do tempo permite que, em vários momentos, outros estudos $Q$ sejam conduzidos com os mesmos indivíduos e a mesma amostra (McKEOWN e THOMAS 1988; BARBOSA e col. 1998).

É através da ordenação Q (Q-Sorting) que o individuo modela e revela o seu ponto de vista, ou seja, através da ordenação dos itens da amostra $Q$ ao longo de um continuum ("mais gosta" /"mais concorda"/"acredita ser mais importante" num extremo até "menos gosta"/"menos concorda"/acredita ser menos importante" no outro extremo), em função de uma condição de instrução. A condição de instrução nada mais é do que uma assertiva que contextualiza a situação para a ordenação dos itens, como por exemplo: "Ordene os itens de acordo com o seu sentimento (sua opinião) em relação a..." (MCKEOWN e THOMAS 1988; BARBOSA e col. 1998).

Os estudos podem ser classificados em:

a) Em função da condição de instrução: 
retrospectivos - p. ex: Como você se sentia a respeito deste assunto há um ano?;

prospectivos - o processo pode ser repetido após uma intervenção, o que permite avaliar a mudança de atitude em um grupo ou um único individuo.

b) Em função da unidade de estudo:

extensivos - com o estudo de vários indivíduos;

intensivos - diferentes condições de instrução são apresentadas ao mesmo indivíduo para a mesma amostra $Q$; p.ex.: Como você se sente em relação a este assunto? Como você acha que sua mãe se sente? E seu companheiro? E seu médico?).

Cada sentença que compōe a amostra $Q$ é registrada, ao acaso, em um pequeno cartão numerado. Os cartões numerados são apresentados ao respondente e este é instruido a operar de acordo com a condição de instrução. O respondente é, então, solicitado a ler todas as frases nos cartões e separá-las em 2 pilhas: uma com os itens com os quais concorda, e outra com aqueles dos quais discorda. Não é necessário que as pilhas contenham o mesmo número de cartões (McKEOWN e THOMAS 1988; BARBOSA e col. 1998).

Um diagrama de uma escala invertida com distribuição forçada quasi-normal (Figura 1) é apresentada aos respondentes. A escala pode se estender de 
+3 a -3, ou +4 a -4, ou +5 a -5 , dependendo do número de sentenças. $A$ distribuição é simétrica em torno do centro, mas geralmente mais achatada do que uma distribuição normal. Tanto a amplitude quanto o formato da distribuição são arbitrários, não têm efeito na análise estatistica, e podem ser modificados de acordo com a conveniência. Os extremos desta distribuição representam opostos polares em um continuum de sentimentos pessoais em relação às frases selecionadas. Posições intermediárias representam sentimentos menos fortes, neutralidade ou ambivalência. Além disso, o padrão quasi-normal da distribuição responde às exigências estatisticas da análise fatorial (McKEOWN e THOMAS 1988; BARBOSA e col. 1998).

O sujeito é, então, instruido a, na pilha com os cartões com os itens com os quais concorda, selecionar aquele(s) com o(s) qual(is) concorda mais intensamente. Este(s) deverá(ão) ser colocado(s) na coluna mais extrema à esquerda na escala invertida (McKEOWN e THOMAS 1988; BARBOSA e col. 1998). No exemplo da Figura 1, o sujeito deveria selecionar as 3 frases que mais correspondem ao seu ponto de vista e colocá-las sob a coluna da extrema esquerda (mais concordo). 
Figura 1- Formato geométrico de uma ordenação $Q$, com distribuição invertida quasi-normal.

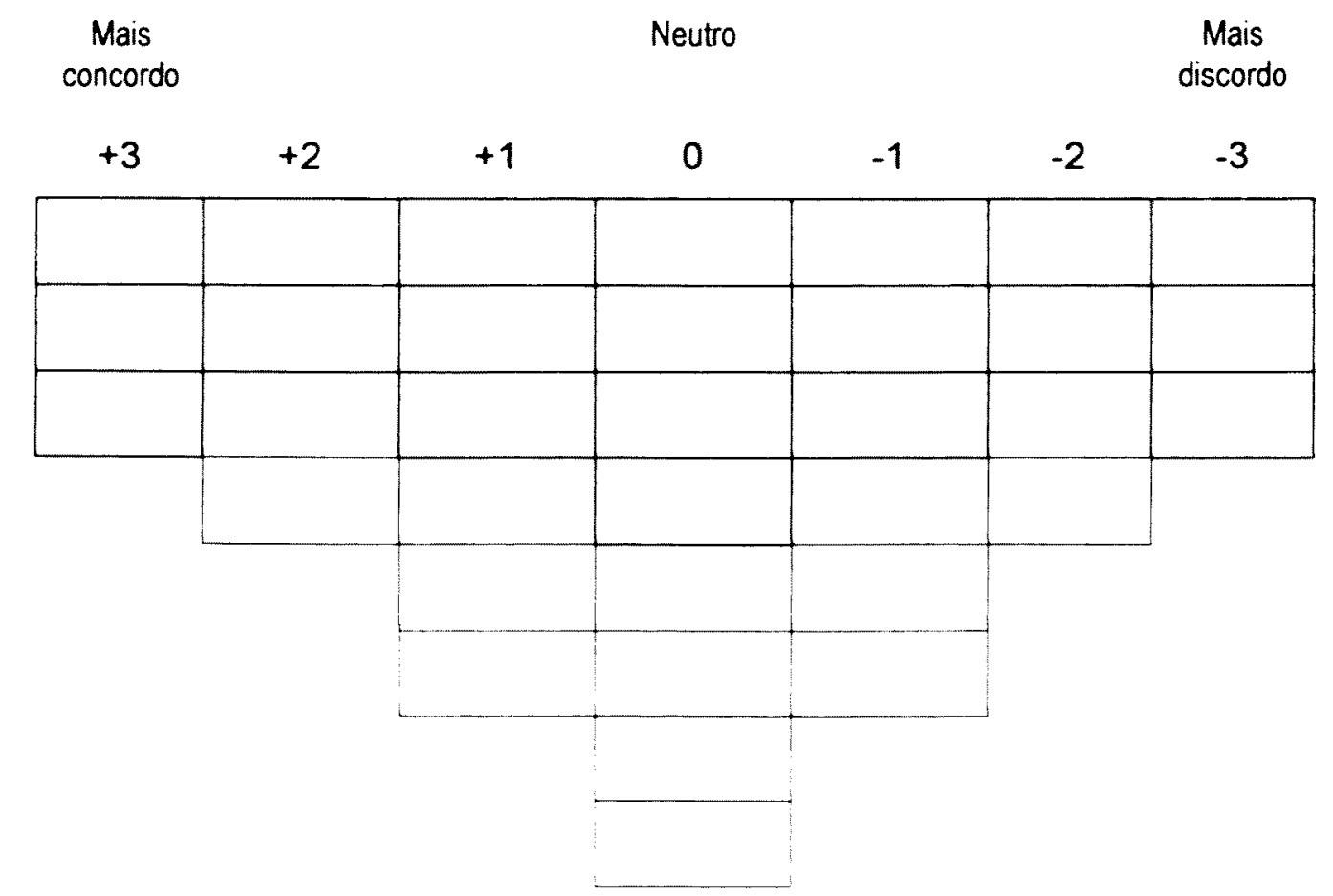

A seguir, a partir da coluna extrema e em direção ao centro, o respondente é instruido a selecionar e colocar na escala os cartões com as frases com as quais ainda concorda, porém menos intensamente. O processo continua atẻ que todos os cartões com frases com as quais concorda estejam posicionados, da esquerda para a direita. Se faltarem cartões, o respondente deverá passar para a próxima etapa do processo. Se sobrarem cartões, estes deverão ser acrescentados à outra pilha (McKEOWN e THOMAS 1988; BARBOSA e col. 1998)

Durante o processo de Q-Sorting, o respondente deve constantemente avaliar e pesar o significado de cada frase em relação a todas as outras. Assim, é durante este processo que, sob a condição de instrução, o sujeito 
arruma as sentenças de forma a melhor modelar o seu ponto de vista, permitindo uma sintonia fina dos sentimentos subjetivos (McKEOWN e THOMAS 1988; BARBOSA e col. 1998).

A seguir, o respondente é instruido a voltar sua atenção para a pilha com as frases das quais discorda, selecionando o(s) item(n)s que, dentre todos, discorda mais intensamente e colocando-o(s) sob a coluna da extrema direita. Os mesmos passos relativos às colunas da esquerda são repetidos no lado direito da escala até que todas as frases de discordância estejam posicionadas da direita para a esquerda (McKEOWN e THOMAS 1988; BARBOSA e col. 1998).

Os itens que sobram após o preenchimento de todas as colunas positivas e negativas são colocados no marco intermediário (neutro). O respondente é livre para trocar as frases e rearranjá-las, de forma que a ordenação final melhor represente seu ponto de vista. Cada coluna deverá conter o número exato de itens indicados na distribuição (McKEOWN e THOMAS 1988; BARBOSA e col. 1998).

Ao término do processo de ordenação, o respondente anotará os números dos cartões correspondentes nas células do diagrama (um número em cada célula). Os "Q-Sorts" são, então, coletados e analisados (McKEOWN e THOMAS 1988; BARBOSA e col. 1998). 


\section{Entrada de dados:}

A análise fatorial "por pessoa" pode ser realizada com o uso de qualquer pacote estatístico que proceda à análise fatorial. No entanto, para a identificação de grupamentos de pessoas em fatores, os Q-Sorts são as variáveis, e os casos são as frases do Q-sample ordenadas pelo respondente. Pacotes estatisticos específicos, que facilitam a entrada dos QSorts e todo o processo de rotação dos eixos e cálculo dos escores dos fatores, foram desenvolvidos, conforme mencionado anteriormente (MCKEOWN e THOMAS 1988; BARBOSA e col. 1998).

Quando se usa o programa especifico de análise, o processo de entrada dos dados se inicia com a informação sobre a estrutura do estudo. Inicialmente, o texto com os itens do Q-sample é digitado e a estrutura do Q-Sort é especificada (escala), o que inclui o número de linhas e colunas. Cada QSort de cada respondente é digitado. O computador checa a soma aritmética final de cada entrada (que deve ser igual a zero) e notifica o digitador a respeito de qualquer número (item) que esteja faltando ou em duplicata. Uma vez que o Q-Sort é digitado, ele é mostrado na tela como uma distribuição quasi-normal, possibilitando a verificação da correção dos nủmeros no Q-Sort (ATKINSON 1992)

\section{E. Análise de dados:}

O processo inicial de análise de dados produz uma tabela de intercorrelação entre os Q-Sorts, a matriz de correlação Q. Esta matriz é submetida a 
análise fatorial por pessoa (método centróide ou análise por componentes principais), e os fatores são extraídos. Após a extração dos fatores, uma tabela, que lista o grau de correlação de cada Q-Sort com cada um dos fatores que não sofreram rotação, é criada. Esta tabela descreve os loadings de cada respondente em cada um dos fatores. Cada loading é avaliado. Se um fator que emerge tem pequenos graus de correlação com os Q-Sorts (ou eigenvalues menores do que a unidade), este pode ser eliminado. Neste ponto, pode ser necessária a rotação dos eixos através do espaço fatorial, na busca de uma solução simples e passivel de interpretação. Uma aproximação para a estrutura simples pode ser obtida através da rotação varimax. Para obter maior simplificação da estrutura fatorial, o investigador pode ainda realizar rotações manuais. É importante enfatizar que a rotação dos eixos, matemática ou manual, não modifica as relações estruturais existentes entre os dados. A rotação simplesmente possibilita a visão e descrição da estrutura fatorial sob diversos ângulos. Desta forma, não há soluções rotacionais certas ou erradas. Cada uma possibilita um grau de interpretação. Em geral, o investigador tenta várias soluções, variando as rotações e o número de fatores consolidados, avaliando cada solução individualmente quanto à clareza de sua descrição e interpretação. Quando o processo de rotação é finalizado, o programa exige a identificação pelo investigador dos Q-Sorts específicos que têm maior peso num só fator. Estes Q-Sorts protótipos definem um fator em particular (McKEOWN e THOMAS 1988; BARBOSA e col. 1998). 
Na dependência do contexto do estudo e de seus objetivos, alguns conceitos inerentes à análise fatorial $R$, tais como eigenvalues, variância percentual e o número de sujeitos que definem o fator e seus loadings, podem ou não ser elementos importantes na análise $Q$ dos dados (MCKEOWN e THOMAS 1988; BARBOSA e col. 1998).

Os loadings podem ser elevados devido ao número reduzido de assertivas ou porque o Q-sample é constituído de frases muito simples, sem riqueza de idéias. Neste caso, os fatores extraidos podem refletir somente o óbvio, que é de pensamento comum a todos, sem explorar respostas mais interessantes e diversas. Por outro lado, assertivas muito elaboradas podem requerer um pensamento mais sofisticado e provocar respostas idiossincráticas, com baixos loadings, porém com mais significado. Em algumas situações, o interesse do pesquisador é na subjetividade de uma pessoa em particular que, sozinha, pode vir a constituir um fator (McKEOWN e THOMAS 1988; BARBOSA e col. 1998).

Quando a intenção do estudo é identificar padrōes de atitudes ou valores (como é o caso desta pesquisa), além dos loadings, o número de sujeitos que tem loadings elevados num determinado fator também deve ser levado em consideração no processo de seleção final e interpretação dos dados. $O$ número destes sujeitos é elemento importante para o cálculo da confiabilidade do fator. Este coeficiente está envolvido no cálculo do erro padrão dos escores dos fatores e do erro padrão da diferença entre os fatores (que avalia se os escores dos fatores são significativamente 
diferentes entre os fatores). Estes valores são automaticamente calculados pelo pacote estatístico PQMethod e fornecidos para interpretação no produto final, de acordo com os seguintes algoritmos:

$$
\begin{aligned}
& r x x=\frac{0,80 p}{1+(p-1) 0,80} \\
& \text {, onde: } \\
& r_{x x}-\text { confiabilidade do fator } \\
& p \text { - número de pessoas definindo o fator } \\
& 0,80 \text { - coeficiente de confiabilidade teste/re-teste }
\end{aligned}
$$

$$
\begin{aligned}
& \mathrm{SEfm}_{\mathrm{fm}} \mathrm{Sx}_{\mathrm{x}} \sqrt{1-r_{x x}} \\
& \mathrm{SE}_{\mathrm{fm}} \text { - erro padrão para cada um dos escores dos fatores } \\
& \text { Sx - desvio padrão do Q-Sort }(=1) \\
& r_{x x}-\text { confiabilidade do fator }
\end{aligned}
$$

\section{F. Interpretação dos resultados:}

A posição relativa de cada frase ao longo de um eixo multidimensional ordenado é calculada com um factor score de cada um dos fatores identificados, criando um Q-Sort de síntese para cada fator. Ou seja, escores dos fatores são essencialmente z-escores para cada frase no Q-sample que podem ser reconvertidos numa factor array, correspondendo aos valores da 
mesma escala utilizada no Q-Sort original. Os escores com valores acima de +1,0 e abaixo de $-1,0$ são considerados importantes para a compreensão da "mensagem do fator". Estes Q-Sorts de sintese são expressos numa tabela de escores dos fatores, que representa o grau de concordância para cada item do Q-sample no fator em particular (McKEOWN e THOMAS 1988; BARBOSA e col. 1998).

A partir dessa informações, categorias descritivas sobre atitudes podem ser induzidas a partir dos escores dos fatores das frases em cada fator. Esta etapa interpretativa é crucial, e a participação dos diversos colaboradores do estudo é importante para dar significado aos fatores obtidos. Inicialmente, as sentenças características de cada fator são identificadas pelos seus escores mais altos ou mais baixos para cada fator. Estas frases determinam as expressões mais importantes de opinião ("gosto/não gosto", "concordo/discordo") para a definição de cada grupo de atitudes. Informações adicionais podem ser obtidas pelo estudo cuidadoso dos escores dos fatores de cada frase em cada fator resultante, independente do escore - positivo, negativo ou neutro (McKEOWN e THOMAS 1988;

BARBOSA e col. 1998).

Entrevistas posteriores com sujeitos do estudo cujos escores em um fator sejam elevados podem acrescentar informações importantes a respeito daquele ponto de vista. Alguns respondentes podem ter loadings num único fator e constituem o que se denomina "os definidores de fatores". Outros respondentes compartilham graus diversos de loading em dois ou mais 
fatores (pontos de vista). Os grupos de atitudes identificados em um estudo utilizando a Metodologia Q não revelam a prevalência deste ponto de vista numa população maior. Ocasionalmente, é importante prestar atenção especial a alguns fatores, mesmo definidos por poucos Q-Sorts, quando estes representam as opiniões ou sentimentos de individuos de particular importância no contexto do assunto em estudo: líderes, pessoas-chave etc. (MCKEOWN e THOMAS 1988; BARBOSA e col. 1998).

\subsubsection{Os viéses na Metodologia Q:}

A liberdade que cada respondente tem em rearranjar os itens do Q-Sort, imputando-Ihe um significado pessoal até que o arranjo final represente de forma adequada (segundo sua própria opinião) o seu ponto de vista pessoal a respeito do tema em estudo é a base da validade e robustez da Metodologia Q. Este enfoque é totalmente diferente do preenchimento de um questionário, selecionando opções de escolha limitada a respeito de frases escritas por investigadores que podem não ver o problema da mesma forma que os respondentes (BARBOSA e col. 1998, McKEOWN e THOMAS 1988, BROWN 1980).

No entanto, esforços devem ser dirigidos para identificar viéses em potencial e minimizá-los. Na Metodologia Q, o termo "validade" diz mais respeito à possibilidade de que o respondente represente seu ponto de vista a partir das frases a ele apresentadas no Q-sample. Esta informação pode e deve ser checada através de uma pergunta ou de uma entrevista após o 
preenchimento da escala invertida (BARBOSA e col. 1998, McKEOWN e THOMAS 1988, BROWN 1980).

A fim de limitar a ocorrência de viéses, algumas estratégias devem ser seguidas pelo investigador interessado em conduzir um estudo $Q$ (BARBOSA e col. 1998, McKEOWN e THOMAS 1988, BROWN 1980):

A. na condição de instrução devem ser evitadas situações artificiais, que forcem os respondentes a basear suas opções a partir de um referencial teórico;

B. o Q-sample deve ser abrangente, amplo e diverso, a fim de permitir uma representação adequada de todas as idéias principais observadas no concourse of ideas;

C. a condição de instrução deve ser especifica, a fim de guiar o respondente a modelar seus sentimentos subjetivos no Q-Sort;

D. os respondentes devem ser selecionados com base na sua suposta diversidade de sentimentos, opiniōes e atitudes, num esforço de revelar o mais possível a respeito da estrutura básica da subjetividade.

Em relação ao processo de rotação dos eixos e interpretação dos resultados, a adequação de uma determinada solução reside na sua capacidade de simplificar a estrutura do fator. Tudo o que traz significado indutivo ao investigador é considerado adequado, ou seja, resultante de uma rotação apropriada. Nenhuma generalização, em termos de freqüência de 
ocorrência do evento, é adequada. Da mesma forma, não se afasta a possibilidade de que outros pontos de vista existam numa população maior (BARBOSA e col. 1998, MCKEOWN e THOMAS 1988, BROWN 1980).

Em sintese, a Metodologia Q se propõe à identificação de grupos de individuos baseada inteiramente na similaridade de suas atitudes em relação a um tema, revelando a diversidade subjetiva que pode ser encontrada entre as pessoas. Numa fase posterior, a partir das frases extremas que compõem os fatores identificados, questionários ou escalas (tipo Likert) poderiam então ser construidos, permitindo a determinação da prevalência desses pontos de vista em amostras representativas da população.

\subsection{LOCALESTHEHOS DE ESTUDO:}

\subsubsection{Aspoctoo Etcos:}

O projeto desta pesquisa foi aprovada pelo Comitê de Ética em Pesquisa COEP da Faculdade da Saúde Pública da Universidade de São Paulo em reunião ordinária de 07/12/1999.

\subsubsection{Procedimentos:}

Em período de seis a 24 meses após o parto, foram explorados os aspectos subjetivos relativos à vivência da maternidade em adolescentes que ficaram grávidas quando tinham de 10 a 14 anos de idade. A escolha deste período se fez porque é somente após decorridos seis meses do parto que o papel materno está bem definido e diminui o apoio da rede social (MERCER 1985). 
Foram elegiveis para o estudo as mães com as características acima, primíparas ou não. Os critérios de exclusão foram: mães adolescentes com patologias crônicas (diabetes, lúpus etc.) ou com filhos com doenças graves (p. ex.: paralisia cerebral, síndromes genéticas, cardiopatias congênitas etc.), uma vez que estas características possivelmente modificam a percepção da maternidade que é objeto deste estudo.

Optou-se por realizar este estudo em unidades públicas de saúde que prestam assistência à criança, e não no nível comunitário, não somente pela facilidade de acesso, mas sobretudo pelas condições de segurança pública. Esta estratégia limitou a população de estudo a um grupo selecionado de jovens mães, ou seja, àquelas que têm acesso aos serviços ambulatoriais de saúde.

Após contatos administrativos necessários, foram selecionadas quatro unidades do Sistema Único de Saúde que prestam atendimento ambulatorial à criança no Município do Rio de Janeiro:

- Instituto de Puericultura e Pediatria Martagão Gesteira (IPPMG) da Universidade Federal do Rio de Janeiro: ambulatório materno-infantil em hospital universitário (onde a autora desempenha suas atividades docente-assistenciais);

- Posto de Assistência Médica (PAM) Madre Tereza de Calcutá da Secretaria Municipal de Saúde do Rio de Janeiro: ambulatório de puericultura e de pediatria em unidade de atenção primária; 
- PAM Rodolpho Rocco da Secretaria Municipal de Saúde do Rio de Janeiro: ambulatório de pediatria e pronto-atendimento em unidade de grande porte;

- Unidade Integrada de Saúde Hamilton Land (UISHL) da Secretaria Municipal de Saúde do Rio de Janeiro: ambulatório integrado de assistência à adolescente grávida e puérpera e a seu filho em unidade de atenção primária.

A escolha dessas unidades de saúde foi feita não somente por conveniência (facilidades, contatos pessoais), mas também com a finalidade de garantir uma amostra minima de participantes do estudo, com diversidade de opiniões e experiências.

A partir das informações obtidas em contatos iniciais com profissionais de saúde que prestam atendimento a adolescentes ou assistência pediátrica nessas unidades, esperava-se que adolescentes elegiveis fossem facilmente identificadas. No entanto, após quatro visitas infrutíferas ao PAM Madre Tereza de Calcutá e ao PAM Rodolpho Rocco, em horários e dias diversos, a coleta de dados limitou-se ao IPPMG e à UISHL.

O Ambulatório Materno-Infantil do IPPMG presta assistência pré-natal a mulheres moradoras da Área Programática 3.1 (AP 3.1) e a pacientes de risco, encaminhadas por outras unidades de saúde. Desenvolve um programa especial voltado para gestantes adolescentes, que moram tanto na AP 3.1 quanto em outras áreas do município e em municípios vizinhos. 
Após o parto, a quase totalidade dos bebês é atendida no mesmo ambulatório, no setor pediátrico. Em setembro de 1999, cerca de 18 mães com idades entre 11 e 16 anos tinham seus bebês sendo acompanhados nesse setor.

A UISHL está situada na comunidade de Cidade de Deus, área carente de Jacarepaguá, bairro da Zona Oeste do Rio de Janeiro (AP 4). Fundado em 1992, o Programa de Assistência Multidisciplinar à Mãe e à Gestante Adolescente dessa unidade presta assistência integral a adolescentes grávidas e puérperas através de atendimento individualizado e em grupos. No mesmo dia em que é realizada a consulta de puericultura, com acompanhamento dos filhos das adolescentes, é realizado o atendimento em grupo e o seguimento do planejamento familiar pelo pediatra (FAGIM e col. 1998).

\subsection{A COLETA DE DADOS:}

\subsubsection{Elaboração do concourse of ideas:}

Para a elaboração do concourse of ideas, foram colhidas opiniões e idéias a partir de grupos focais realizados com adolescentes de 10 a 14 anos e mães adolescentes de 10 a 16 anos, da literatura especializada e da mídia.

Foram realizados quatro grupos focais. O processo foi áudio-gravado e as fitas foram posteriormente transcritas, analisadas e destruidas. As seguintes perguntas foram apresentadas aos grupos: 
- "O que você gosta e não gosta de fazer?";

- "O que você considera importante na sua vida?";

- "Como é a sua vida agora?";

- "Como você espera que seja a sua vida no futuro?"

Dois grupos focais foram realizados em setembro de 1998 com adolescentes de 10 a 14 anos, estudantes de duas escolas públicas de primeiro grau. Para ambos, foram feitos contatos com os diretores das escolas, que foram esclarecidos quanto aos objetivos do estudo e à atividade proposta. Nas salas de aula, apresentou-se o estudo aos alunos e solicitou-se a participação voluntária. Ás adolescentes interessadas foi requisitado consentimento por escrito dos responsáveis (Anexo 1) e, somente após o "de acordo", foi realizada a atividade de grupo.

Em janeiro de 1999, foram realizados outros dois grupos focais com mães adolescentes cujos bebês eram atendidos no Ambulatório Materno-Infantil do IPPMG. Foram feitos contatos telefônicos e por carta; os objetivos do estudo foram detalhados e foi solicitada a participação voluntária. No dia agendado para a atividade, foi solicitado consentimento informado e os custos de transporte foram ressarcidos.

A partir das atividades de grupo, da literatura e da mídia, foram identificadas 87 opiniões a respeito da adolescência e da maternidade na adolescência (Anexo 2). Foram inicialmente identificadas as seguintes categorias de 
significado: culpa, perdas e medo. Para a montagem do Q-sample, buscouse aliar a variedade de opiniões com facilidade de procedimentos, levando em conta a idade e nivel de escolaridade do grupo em estudo. O processo de seleção das assertivas foi submetido à apreciação de um observador independente, familiarizado com as etapas da Metodologia $Q$.

Procurou-se montar uma amostragem estruturada em que as três categorias de significado estavam representadas de forma homogênea, através da seleção de seis frases que buscavam representar a dimensão polar de cada categoria. Desta forma, o Q-sample foi estruturado com 36 frases (Anexo 3).

\subsubsection{Coleta de dados propriamente dita:}

A coleta de dados se deu no período de agosto a dezembro de 2000 . As adolescentes foram identificadas na triagem e nas salas de espera do Ambulatório Materno-Infantil do IPPMG e nos grupos de mães adolescentes da UISHL. O processo de coleta de dados constou de dois procedimentos distintos: uma entrevista inicial e a ordenação das frases.

Após a obtenção do Consentimento Informado e Esclarecido (Anexo 4), as mães adolescentes foram solicitadas a proceder à ordenação dos 36 cartões, a partir da condição de instrução:

"A partir da sua experiência de vida, como é ser mãe na sua idade?"

Foram, então, apresentadas à escala invertida, reproduzida em tamanho ampliado, semelhante à dos tabuleiros de jogos de salão. Este procedimento visou não somente facilitar a visualização do processo, como também dar à 
experiência um aspecto lúdico e descontraido. Durante o processo de ordenação, as adolescentes foram estimuladas a mudar a posição dos cartōes o quanto quisessem, a fim de que a posição final melhor representasse o seu ponto de vista. Com a ajuda da adolescente, ao término da ordenação, os números entre parênteses ao final de cada frase foram cuidadosamente reproduzidos pela entrevistadora na escala do formulário de coleta de dados (Anexo 5).

Neste momento já havia sido estabelecido um vínculo de confiança e descontração entre a adolescente e a entrevistadora e procedeu-se, então, a entrevista. As respostas foram anotadas em formulário próprio, impresso no verso da escala semi-invertida (Anexo 6).

As perguntas da entrevista buscaram descrever as condiçōes de vida da adolescente e seu filho, a fim de fornecer subsidios para a interpretação dos resultados:

perfil demográfico: nome, endereço completo, telefone para contato, idade da adolescente, do pai da criança e do lactente; perfil sócio-econômico-familiar:

- composição familiar: descrição do núcleo familiar no domicilio (pai da criança, outro parceiro, familia original. etc.);

- situação conjugal: com ou sem união conjugal;

- situação de domicilio: dependente (com mais de uma familia no mesmo domicílio) ou independente (próprio ou alugado);

- escolaridade: se ainda estuda ou não; última série completada; 
- trabalho: se trabalha com remuneração ou não, tipo de atividade e renda;

- renda familiar: número de provedores; renda familiar e renda per capita;

história de gravidez/parto e neonatal:

- número de gestações e paridade;

- realização de exame pré-natal e número de consultas; intercorrências;

- tipo de parto; intercorrências;

- tempo de amamentação exclusiva

sexualidade:

- idade da primeira relação sexual;

- ter companheiro ou namorado no momento atual;

- ter vida sexual;

- uso de método contraceptivo e tipo de método.

A última pergunta buscou a síntese objetiva da experiência da maternidade na vida da adolescente:

"Sua vida hoje é melhor ou pior do que antes de ficar grávida?

\section{Por quê?"}

\subsection{A ANALISE DOS DADOS:}

O perfil das adolescentes foi inicialmente analisado através de uma abordagem descritiva (médias e proporções de suas características sóciodemográficas), utilizando-se para tal o programa EPIINFO (versão 6.0b), de 
domínio público.

Para a análise fatorial das opiniões das adolescentes a respeito das vivências da maternidade, foi utilizado o programa PQMethod (versão 2.09).

Optou-se pela extração de fatores através do método de Análise por Componentes Principais (PCA). Os fatores com eigenvalues acima de 1,00 foram considerados significativos e a rotação destes fatores foi realizada através do método varimax e de rotação manual, a fim de obter uma solução simples e passivel de interpretação. 


\section{RESULTADOS:}

Na realização deste estudo, foi possivel observar que, em pelo menos cinco importantes serviços de saúde materno-infantil que prestam assistência direta ou indiretamente à adolescente na cidade do Rio de Janeiro, a população elegivel para esta pesquisa (mães de bebês entre seis e 24 meses de idade, que ficaram grávidas com idade de 10 a 14 anos) é dispersa e consideravelmente menor do que referem os profissionais que prestam atendimento nestas unidades. Alguns serviços organizam-se para o atendimento diferenciado destas gestantes no pré-natal, com dias e horários especiais, e com atividades de grupos. Com a exceção da UISHL, o mesmo tipo de organização não é observado na atenção à adolescente após o parto ou na atenção ao filho de adolescente nas demais unidades de saúde. Desta forma, a captação de jovens elegiveis para este estudo se deu a partir da população materno-infantil geral atendida nos ambulatórios de pediatria, e foi tarefa árdua e demorada.

No total foram abordadas 22 jovens elegíveis. Duas delas (ambas na UISHL) recusaram-se a participar do estudo e 20 mães adolescentes foram entrevistadas: 15 no IPPMG e cinco na UISHL.

O processo de Q-sorting e entrevista se deu antes da consulta médica, com a presença da adolescente e seu filho e da entrevistadora, em local silencioso, previamente arrumado com mesa e cadeiras. Em algumas ocasiões foi necessária a ajuda de acompanhante para o cuidado da criança, uma vez que esta solicitava a atenção da mãe e impedia a 
realização da coleta de dados. Todo o processo transcorreu sem dificuldades de comunicação e durou cerca de 30-40 minutos para cada adolescente. Ao término de cada entrevista a jovem mãe era reapresentada ao seu Q-sort e solicitada a realizar, se necessário, qualquer alteração até que uma solução final melhor representasse sua opinião.

Devido a dificuldades logísticas, após a análise dos resultados não foi possivel recontatar as adolescentes que, sozinhas, definiam um fator ( $Q$ sorts $n^{\circ} 6$ e 7 ) e a adolescente mixed loader ( $Q$-sort $\left.n^{\circ} 16\right)$, que apresentou loadings significativos em dois fatores (vide Tabela 6).

A partir dos dados do setor de matricula e agendamento, observa-se que as 15 adolescentes entrevistadas no IPPMG correspondem a cerca de $85 \%$ das jovens elegíveis atendidas no Ambulatório Materno-Infantil. Já na UISHL, segundo informações verbais, as cinco jovens entrevistadas correspondem a cerca de $50 \%$ das adolescentes elegiveis acompanhadas no serviço. Os dados gerais e de cada unidade de saúde estão descritos abaixo e sintetizados nos Anexos 7 e 8 .

A descrição das características das adolescentes tem por objetivo traçar um retrato geral do grupo estudado e fornecer subsídios para a interpretação dos resultados, sem pretensão de generalizá-los. Da mesma forma, a descrição do perfil das jovens mães em cada unidade de saúde tem também como propósito verificar se foi alcançada a diversidade de experiências que era pretendida ao se realizar o estudo em diferentes unidades de saúde. 


\subsection{ANÁLISE DESCRITIVA:}

\subsubsection{Resultados globais:}

A maior parte das adolescentes $(70,0 \%)$ residia no Municipio do Rio de Janeiro; as outras jovens eram oriundas de municipios da periferia.

A média de idade das adolescentes foi $15,0 \pm 0,5$ anos, sendo que a mais jovem entrevistada tinha 14 anos de idade; a média de idade do pai da criança foi $20,3 \pm 3,8$ anos e a da criança foi $11,6 \pm 5,8$ meses. A diferença entre as médias de idade da adolescente e do pai da criança foi cerca de 5,3 anos. A média de idade da primeira relação sexual foi $12,5 \pm 0,5$ anos A maior parte das adolescentes não morava com o pai de seu filho $(60,0 \%)$, mas residia em domicilio familiar independente $(60,0 \%)$ e próprio $(80,0 \%)$ Cerca de $40,0 \%$ das jovens mães estavam estudando e metade das adolescentes havia tido pelo menos seis anos de educação formal. Nenhuma adolescente trabalhava no momento. A renda familiar média era $R \$ 570,00 \pm 322,00$, o que correspondia a cerca de 3,7 salários-mínimos (SM) vigentes. A renda per capita média foi de $\mathrm{R} \$ 129,40 \pm 83,30$, que correspondia a aproximadamente 0,9 SM, acima portanto do nivel de pobreza (FUNDAÇÃO GETÚLIO VARGAS 2001).

Para $75,0 \%$ das jovens esta havia sido sua primeira gravidez. Foram relatados quatro abortamentos prévios, um espontâneo e três provocados. Todas haviam feito acompanhamento pré-natal, mas somente $60,0 \%$ tinham 
tido seis ou mais consultas. Cerca de $25,0 \%$ das adolescentes referiram intercorrências durante o período pré-natal. O parto foi cesáreo em 45,0\% dos casos, e $40,0 \%$ das jovens referiram intercorrências no período perinatal, principalmente doença hipertensiva da gravidez e prematuridade. Trinta por cento das crianças tinham peso ao nascimento abaixo de $2500 \mathrm{~g}$, e a mediana do tempo de aleitamento materno exclusivo foi de 90 dias.

A maior parte das jovens estava namorando/tinha companheiro $(75,0 \%)$ e $80,0 \%$ referiam vida sexual. A grande maioria fazia uso de algum método anticoncepcional $(85,0 \%)$, sendo a pílula o principal método de escolha $(76,5 \%)$, seguido pelo uso isolado do condom $(17,6 \%)$.

A maior parte das adolescentes $(70,0 \%)$ referiu que sua vida é pior hoje do que antes de ficar grávida.

\subsubsection{NoIPPMG:}

No IPPMG, foram entrevistadas 15 adolescentes. Nove moravam no município do Rio de Janeiro, sendo sete no Complexo da Maré (conjunto de várias comunidades carentes, com áreas urbanizadas e áreas de favela), e seis eram oriundas de municípios da Baixada Fluminense (Região Metropolitana). A diferença das médias de idade entre as adolescentes e os pais de seus filhos foi de cerca de 5 anos; enquanto a idade média das adolescentes foi $15,0 \pm 0,5$ anos, a dos pais das crianças foi 20,2 anos $\pm 3,8$ anos. As crianças tinham em média 11,7 $\pm 6,3$ meses de idade. Ao engravidarem, as adolescentes tinham 12,9 $\pm 0,4$ anos. 
Sete adolescentes residiam com os pais de seus filhos; onze delas moravam em domicilios independentes, ou seja, constituidos por um único núcleo familiar; a residência era própria na maior parte dos casos $(73,3 \%)$.

Oito das quinze adolescentes estavam freqüentando a escola, cinco delas em série compativel com a idade (14-15 anos cursando a $8^{a}$ série e 15-16 anos cursando a $1^{\text {a }}$ série do ensino médio) e quase todas (seis) moravam no Municipio do Rio de Janeiro. Das sete adolescentes que haviam abandonado os estudos, cinco moravam em municípios da Região Metropolitana, e três delas, ao largar a escola, estavam em série compativel com a a idade.

Na maior parte dos domicilios (nove), mais de uma pessoa respondia pela provisão da familia. A renda familiar média foi de $R \$ 640,00 \pm 340,00$, correspondendo a cerca de 4,3 SM vigentes. A média de pessoas convivendo no mesmo domicilio foi de $4,7 \pm 2,9$ pessoas e, desta forma, a renda per capita média aproximada foi de quase um SM vigente (R\$148,00 $\pm 86,40)$.

Esta foi a primeira gravidez para doze adolescentes, sendo que uma delas teve parto gemelar. Duas jovens relataram abortamentos provocados em gestação anterior. Uma jovem, logo após um aborto espontâneo, planejou e levou a termo nova gravidez com o mesmo parceiro. Outra jovem, com 16 anos, era mãe de um bebê de quase dois anos e outro de três meses (do mesmo companheiro de 31 anos). Na segunda gestação, não fez exame 
pré-natal, o parto foi cesáreo e o bebê foi prematuro. Mãe e bebê foram diagnosticados com sifilis e receberam tratamento (a criança ficou internada durante 28 dias). O pai da criança, no entanto, recusou-se a fazer o exame e o tratamento.

Para a gravidez alvo do estudo, todas fizeram exame pré-natal, mas somente nove das quinze adolescentes compareceram a seis ou mais consultas. Cinco adolescentes relataram intercorrências durante a gravidez: ameaça de abortamento/parto prematuro (duas), hiperemese necessitando internação (uma), condiloma acuminado (uma) e anemia (uma).

Em oito jovens o parto foi cesáreo $(53,3 \%)$. Sete adolescentes relataram intercorrências no período perinatal, sendo que prematuridade foi a mais freqüente (cinco partos prematuros, não incluido o parto gemelar), seguida de pré-eclâmpsia (em três jovens). Quarenta por cento das crianças tinha peso ao nascimento abaixo de $2500 \mathrm{~g}$ e a mediana do tempo de aleitamento materno exclusivo foi de 90 dias.

A primeira relação sexual foi por volta dos 12 anos de idade $(12,4 \pm 0,5$ anos). Doze adolescentes tinham namorado (ou companheiro) e onze delas referiram atividade sexual no momento. A jovem cujo marido recusava-se a realizar exame e tratamento para sífilis relatou não estar se relacionando sexualmente com seu parceiro desde o nascimento do segundo filho. Todas as doze adolescentes faziam uso de algum método anticoncepcional: dez usavam pílula, uma fazia uso de hormônio injetável e somente uma relatou 
uso de condom.

Dez adolescentes responderam que se não tivessem ficado grávidas suas vidas seriam mais simples e melhores. Alegaram que teriam menos responsabilidades e mais liberdade, mais tempo para diversão e estudo; não teriam que renunciar ou dividir. Duas delas chegaram a lamentar a solidão e a falta de amigos, além das dificuldades emocionais e familiares que estão enfrentando. Três jovens, entretanto, referiram ter hoje mais liberdade, menos conflitos familiares e mais alegria em suas vidas. Apesar de reconhecerem a carga de trabalho e responsabilidade, a vida ficou melhor após o nascimento de seus filhos. Duas jovens relataram não ter havido mudança substancial em suas vidas com a maternidade, com perdas e ganhos equilibrados.

\subsubsection{Na UISHL:}

Na unidade da Cidade de Deus, foram entrevistadas cinco adolescentes, todas moradoras da comunidade.

Todas as adolescentes tinham 15 anos de idade, e a idade média dos pais das crianças foi $20,4 \pm 4,3$ anos, mantendo uma diferença etária de cerca de cinco anos. As crianças tinham em média 11,2 $\pm 4,1$ meses de idade. Desta forma, quando engravidaram, as adolescentes tinham em média 13,0 $\pm 0,0$ anos.

Somente uma adolescente residia com o pai de seu filhos e em domicilio independente; as outras quatro moravam em domicilios constituídos por 
mais de uma família, e a residência era própria em todos os casos.

Nenhuma jovem freqüentava a escola, e somente uma delas, ao largar a escola, estava em série compatível com a idade.

Nenhuma adolescente desempenhava atividade profissional remunerada e em quatro domicilios somente uma pessoa era o provedor da família. A renda familiar média foi $R \$ 352,00 \pm 50,00$, correspondendo a cerca de 2,3 SM da época. A média de pessoas convivendo do mesmo domicílio foi $5,8 \pm$ 2,6 pessoas. Assim, a renda per capita média aproximada foi de menos de meio $S M$ vigente $(R \$ 72,00 \pm 37,50)$.

Esta foi a primeira gravidez para três adolescentes. Duas jovens relataram abortamentos provocados em gestação anterior.

Para esta gravidez, todas fizeram exame pré-natal, sendo que duas adolescentes compareceram a menos de seis consultas. Nenhuma jovem relatou intercorrências durante a gravidez.

O parto foi cesáreo para uma adolescente, que relatou ameaça de parto prematuro e pré-eclâmpsia. Nenhuma criança nasceu com peso inferior a 2500g, e a mediana do tempo de aleitamento materno exclusivo foi de 120 dias.

Todas as adolescentes tiveram sua primeira relação sexual aos 13 anos. Três tinham namorado (ou companheiro) no momento, e todas referiram atividade sexual. Todas faziam uso de algum método anticoncepcional: três 
usavam pílula e duas, condom.

Quatro adolescentes responderam que, se não tivessem ficado grávidas, suas vidas seriam mais simples e melhores. Alegaram que teriam mais liberdade, menos responsabilidades, a vida seria mais fácil, mais despreocupada, poderiam estudar, trabalhar fora e ajudar no sustento da família. Uma jovem relatou que sua vida não se modificou substancialmente com a maternidade, uma vez que os problemas que enfrentava agora eram os mesmos de antes.

\subsubsection{Diferencas entre os grupos:}

Podem ser observadas algumas diferenças entre os dois grupos de adolescentes entrevistadas, que dizem respeito às seguintes dimensões e variáveis:

- situação sócio-econômica: morar com o companheiro (pai da criança), em domicílio independente; estar estudando no momento; renda per capita no domicílio;

- situação de saúde: intercorrências durante o pré-natal, tipo de parto, intercorrências durante o parto, peso do bebê ao nascimento; tempo de aleitamento materno exclusivo.

Os dados sugerem que as adolescentes entrevistadas na UIS Hamilton Land provêm de meio mais carente que as do IPPMG, com menor escolaridade, menor renda familiar e, provavelmente, com menos apoio familiar (em 
relação ao pai da criança). Por outro lado, as da Cidade de Deus parecem constituir um grupo de menor risco em termos biológicos, em concordância com os diferentes perfis assistenciais das duas unidades de saúde (serviço universitário de referência - IPPMG - e unidade primária de saúde localizada em comunidade carente - UISHL). Desta forma, as diferenças observadas parecem refletir diversidade nas experiências de vida, conforme o pretendido na composição da amostra estudada.

\subsection{ANÁLISE FATORIAL:}

Os principais procedimentos e os resultados da análise fatorial realizada pelos programa PQMethod estão descritos no Anexo 9.

Tendo sido a priori satisfeita a premissa de linearidade (conforme descrito no item 3.2.5.), foi inicialmente avaliado o ajuste dos dados para a análise fatorial através do KMO (Kaiser-Meyer-Olkin Measure of Sampling Adequacy) e do BTS (Bartlett Test of Sphericity), com os seguintes resultados obtidos no programa SPSS for Windows (versão 6.2.1):

Kaiser-Meyer-Olkin Measure of Sampling Adequacy $=0,59274$ Bartlett Test of Sphericity $=472,11140$, Significance $=0,00000$ Apesar de a adequação dos dados para a análise fatorial não ser ideal $(\mathrm{KMO}=0,59)$, a hipótese de não haver correlação entre as variáveis foi afastada (BTS com $P<0,01$ ), possibilitando a continuidade da análise. Após a análise por componentes principais, foram extraidos cinco fatores com eigenvalues acima do valor unitário que, juntos, explicavam cerca de 
$74,0 \%$ das variações das medidas originais.

Após a rotação varimax e a rotação manual, no nível de significância estatistica de $P<0,01$, foram considerados significativos os loadings maiores que 2,58 vezes o erro padrão (SE), ou seja, loadings com valores acima de 0,43 , de acordo com o cálculo abaixo:

$$
\text { SE }=\frac{1}{\sqrt{N}}=\frac{1}{\sqrt{36}}=0,17 \quad \text {, onde: }
$$

$\mathrm{SE}=$ erro padrão

$$
N=\text { número de assertivas (Q-sample) }
$$

Loadings significativos $=0,17 \times 2,58=0,43$

Foram finalmente extraídos quatro fatores com pelo menos um loading maior ou igual a 0,43. A correlação entre os quatro fatores está descrita na Tabela 5 e os baixos coeficientes de correlação $(r<0,5)$ sugerem fraca associação entre eles. Desta forma, os quatro fatores podem ser considerados como formas qualitativamente diferentes e independentes de percepção da vivência da maternidade nas 20 adolescentes estudadas.

Tabela 5 - Coeficientes de correlação $(r)$ entre os quatro fatores.

\begin{tabular}{c|cccc}
\hline Fatores & I & II & III & IV \\
\hline I & 1,00 & 0,15 & 0,34 & 0,44 \\
II & 0,15 & 1,00 & 0,03 & 0,18 \\
III & 0,35 & 0,03 & 1,00 & 0,16 \\
IV & 0,44 & 0,18 & 0,16 & 1,00 \\
\hline
\end{tabular}


Na Tabela 6, estão descritos os loadings em cada fator, alguns dados relativos ao perfil sócio-econômico-familiar e a percepção de cada adolescente de sua vida atual. Pode-se observar que todas as 20 adolescentes apresentaram loadings excedendo a significância estatística $(P<0,01)$. Dezenove $Q$-Sorts foram pure loaders, ou seja, tiveram cargas em somente um dos quatro fatores extraidos, e a adolescente $n^{\circ} 16$ foi um mixed loader (com loadings significativos nos Fatores I e III). Quatorze adolescentes definiram o Fator I e quatro definiram o Fator II. Os Fatores III e IV foram definidos por somente uma adolescente cada.

Em função do pequeno número de Q-Sorts, não é possivel especular a respeito de tendências na distribuição das dimensões descritas. 
Tabela 6 - Distribuição das adolescentes quanto aos loadings nos fatores extraídos (em números aproximados), renda per capita (em SM), escolaridade, situação conjugal e percepção da qualidade de vida atual, Rio de Janeiro, $2000(N=20)$.

\begin{tabular}{|c|c|c|c|c|c|c|c|c|c|c|}
\hline \multirow{2}{*}{\multicolumn{2}{|c|}{ QSORT }} & \multicolumn{4}{|c|}{ FATORES } & \multirow{2}{*}{$\begin{array}{l}\text { Renda } \\
\text { percapta }\end{array}$} & \multirow{2}{*}{$\begin{array}{l}\text { Ainda } \\
\text { estuda? }\end{array}$} & \multirow{2}{*}{$\begin{array}{l}\text { Morad } \\
\text { paiça }\end{array}$} & \multirow{2}{*}{$\begin{array}{l}\text { Suavida } \\
\text { hoje? }\end{array}$} & \multirow{2}{*}{$\begin{array}{l}\text { Unid } \\
\text { des }\end{array}$} \\
\hline & & 1 & 2 & 3 & 4 & & & & & \\
\hline 3 & RRC1 & 0,81 & $-0,26$ & 0,15 & 0,02 & 2,8 & Não & Sim & Pior & IPP \\
\hline 20 & cr & 0,81 & $-0,10$ & 0,22 & 0,15 & 2,0 & Não & Sim & Igual & IPP \\
\hline 8 & RRC2 & 0,76 & 0,17 & 0,11 & 0,18 & 2,5 & Sim & Não & Pior & IPP \\
\hline 13 & WSS & 0,74 & 0,14 & 0,24 & 0,04 & 0,5 & Não & Não & $\mathrm{Pi}$ & UIS \\
\hline 10 & & 0,71 & 0,34 & 0,08 & 0,18 & 7 & Não & Sim & & $|P P|$ \\
\hline 4 & & 0,71 & 0,08 & 0,23 & 0,05 & 0,5 & Sim & Não & $\mathrm{Me}$ & $|\mathrm{PP}|$ \\
\hline 14 & & 0,71 & 0,24 & 0,19 & 0,37 & 0,3 & ão & Não & & UIS \\
\hline 19 & CST & 0,71 & 0,09 & 0,11 & 0,39 & 0,9 & Não & Sim & $\mathrm{Pi}$ & UIS \\
\hline 17 & PS & 0,66 & 0,16 & 0,08 & 0,12 & 2,3 & Sim & Não & Igual & $|P P|$ \\
\hline 16 & & 0,66 & 0,36 & 0,46 & 0,15 & 0,7 & Sim & Sim & $\mathrm{Me}$ & $|P P|$ \\
\hline 9 & DVM & 0,65 & 0,06 & 0,11 & 0,22 & 2,3 & Sim & Não & $P$ & IPPI \\
\hline 15 & $A$ & 0,64 & 0,21 & 0,28 & 0,21 & 0,5 & Não & Não & Igual & UIS \\
\hline 12 & & 0,6 & 0,23 & 0,20 & & & & & & $|P P|$ \\
\hline 11 & & 0,59 & 0,38 & 0,16 & 0 & & ão & Jão & & $|P P|$ \\
\hline 1 & $\Delta$ & 0,19 & 0,71 & 0,04 & 0 & & Não & Sim & & IPPI \\
\hline 5 & SPM & 0,35 & 0,65 & 0,35 & 0,09 & 2,2 & Sim & Não & r & |PPI \\
\hline 2 & PLAA & 0,10 & 0,65 & 0,16 & 0,34 & 0,9 & Sim & Não & $P$ & IPPI \\
\hline 18 & DSD & 0,43 & 0,58 & 0,05 & 0,37 & 0,3 & Não & Não & Pior & UIS \\
\hline 7 & JSB & 0,20 & 0,02 & 0,88 & 0,09 & 0,5 & Sim & Não & Melhor & IPPI \\
\hline 6 & NVG & 0,30 & 0,21 & 0,06 & 0,83 & 0,4 & Não & Não & Pior & IPPI \\
\hline
\end{tabular}

Loadings $\geq 0,43$ são estatisticamente significativos $(P<0,01)$

A partir da análise dos escores dos fatores e das comparaçōes entre os fatores, foi possivel induzir as seguintes categorias descritivas: 


\subsubsection{O Fator I:}

Quatorze jovens mães compõem o Fator I. Treze Q-Sorts são definidores e correspondem às seguintes adolescentes: RRC1, RSG, RRC2, WSS, ACF, LRB, VMC, CST, APS, DVM, DA, JCPN, ICF. A jovem ASL apresentou loadings significativos nos Fatores I e III (mixed loader), ou seja, pode estar apresentando uma atitude confusa ou de transição. O Fator I responde por $37,0 \%$ da variância total, sua confiabilidade é elevada $\left(r_{x x}=0,982\right)$, e o erro padrão dos escores dos fatores é 0,132.

O Q-Sort protótipo que define o Fator I assume a seguinte distribuição:

\begin{tabular}{lllllllll}
-4 & -3 & -2 & -1 & 0 & +1 & +2 & +3 & +4 \\
\hline 8 & 16 & 13 & 2 & 1 & 3 & 7 & 17 & 4 \\
20 & 29 & 22 & 9 & 5 & 6 & 11 & 18 & 30 \\
28 & 35 & 24 & 15 & 10 & 19 & 14 & 26 & 31 \\
& & 34 & 21 & 12 & 25 & 33 & & \\
& & & 23 & 27 & 36 & & & \\
& & & & 32 & & & &
\end{tabular}

As assertivas que representam o Fator I estão listadas abaixo, sendo marcadas com um asterisco aquelas que o distinguem dos outros fatores (significância $-P<0,05)$ :

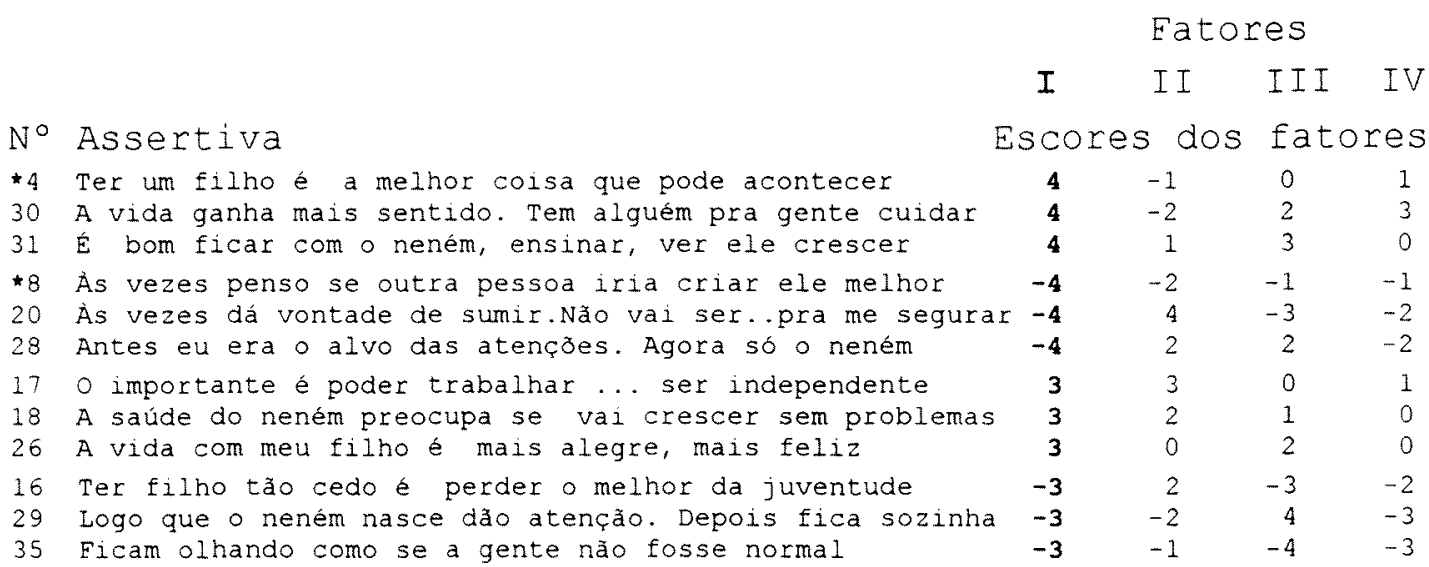


Os resultados acima sugerem que a adolescente que se define neste fator tem uma vivência positiva e enriquecedora em relação à maternidade (\# 4, 20,30 ), com ganhos emocionais efetivos (\# 30, 26) e afirmação da autoestima (\# 8, 35). Assume plenamente o papel socialmente esperado de mãe (orgulhosa do filho, responsável e preocupada) e de adulta, reconhecendo a importância de sua independência financeira (\#31, 18, 17). A passagem de filha/adolescente para mãe/adulta parece se fazer sem traumas, medos, ressentimentos, sobrecargas ou sensação de perdas (\# 28, 16, 29). Ao contrário, a maternidade parece vir preencher um espaço vazio de afeto $(\# 30,26)$. Não percebe dificuldades em relação ao seu grupo social, pelo qual parece ser aceita e apoiada $(\# 20,28,29,35)$. Sua vida parece estar centralizada na figura de seu filho e o que ele representa, uma vez que este está presente, de forma positiva, em quase todas as assertivas.

Para fins de discussão, a adolescente que compõe o Fator I será denominada Satisfeita com a maternidade / Dependente do afeto do filho.

Observam-se algumas aparentes contradições: muitas dessas jovens referiram na entrevista que a vida era hoje pior do que antes da gravidez. Este é o caso de RRC1 (Q-Sort $n^{\circ} 3$ ), que, com o loading mais elevado no fator $(0,81)$, referiu que esta gravidez foi planejada (após um abortamento espontâneo), mas que sua vida hoje era pior. Para ACF (Q-Sort $\left.n^{\circ} 10\right)$, com loading de 0,71 neste fator, a vida hoje está pior do que antes, tem agora um segundo bebê com três meses de idade e não tem relações sexuais com o 
marido desde o último parto, porque este transmitiu-lhe sífilis e não quer se tratar.

Observa-se, no entanto, que todas as adolescentes que referiram que a vida hoje é melhor ou igual a antes da gravidez encontram-se agrupadas no Fator I, com exceção de JSB que define o Fator III, conforme descrito mais abaixo.

\subsubsection{O Fator II:}

Quatro Q-Sorts definem o Fator II, respondendo por $12,0 \%$ da variância total: JAAS, PLAA, SPM e DSD. A confiabilidade do Fator II foi elevada $\left(r_{x x}=0,941\right)$, e o erro padrão dos escores dos fatores foi 0,243 .

A distribuição do Q-Sort protótipo que define o Fator II é:

\begin{tabular}{lllllllll}
-4 & -3 & -2 & -1 & 0 & +1 & +2 & +3 & +4 \\
\hline 6 & 5 & 8 & 4 & 7 & 3 & 16 & 1 & 2 \\
21 & 13 & 10 & 14 & 12 & 9 & 18 & 17 & 11 \\
24 & 27 & 29 & 15 & 19 & 22 & 28 & 33 & 20 \\
& & 30 & 32 & 23 & 31 & 36 & & \\
& & & 35 & 25 & 34 & & & \\
& & & & 26 & & & &
\end{tabular}

As assertivas que representam o Fator II estão listadas abaixo, sendo marcadas com um asterisco aquelas que o distinguem dos outros fatores em nivel de significância $P<0,05$ e com dois asteriscos aquelas com nível de significância $P<0,01$ : 


I
N

As assertivas abaixo, mesmo com baixos z-escores no fator (entre

parênteses), também distinguem o Fator II dos outros fatores, com

significância estatística $-P<0,05\left({ }^{*}=P<0,01\right)$ :

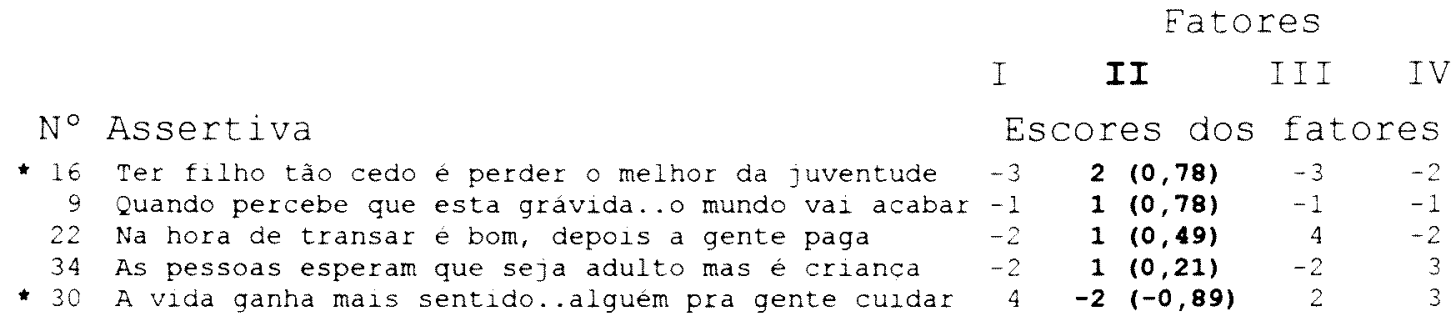

Os dados sugerem que a jovem mãe que define o Fator II vivencia a

maternidade como uma experiência difícil, estressante e solitária, para a

qual não se acha preparada (\# 2, 11, 1, 27). Mostra-se frágil, com tendências

a depressão e a fuga, e em conflito com o companheiro $(\# 2,20)$. As perdas

parecem ser importantes (\# 21). O corpo adolescente pode ser recuperado

(\#5), mas a maternidade não propicia ganhos em beleza adulta (\#6). As

dificuldades para cumprir o papel de mãe são reconhecidas (\#1), e a mulher

adulta está melhor preparada para estes desafios do que a jovem mãe (\#27).

O papel de mãe pode ser aprendido (\#33), mas outra gravidez não é 
desejada no momento (\#24). Percebe a necessidade de independência (\# 17) e não se ressente de pressão social (\# 13). No Fator II, o desejo/ necessidade de independência parece significar mais um desejo de fuga do que representar maturidade, como no Fator I. As necessidades e carências estão no centro da existência do Fator II, e não a relação com o outro (filho, parceiro, familia, vizinhos).

Em relação às adolescentes dos outros fatores, é a que mais se ressente com a perda da juventude (\#16), que percebe dificuldades com a revelação da gravidez (\# 9) e que não reconhece maiores ganhos com a maternidade (\# 30).

A adolescente que define o Fator II será denominada Deprimida /

\section{Estressada.}

Na entrevista, SPM (Q-Sort $n^{\circ} 5$ ), com loading de 0,65 neste fator, referiu que sua gravidez foi desejada, quase planejada. No entanto, ela e as outras três adolescentes que definem este fator relataram que a vida era hoje pior do que antes da gravidez.

\subsubsection{O Fator III:}

O Fator III é definido basicamente por uma adolescente (JSB) e é responsável por $8,0 \%$ da variância do modelo. Conforme descrito acima, ASL é mixed loader neste fator, porém com menor intensidade do que no Fator I. Por esta razão, a confiabilidade do Fator III está prejudicada $\left(r_{x x}=0,800\right)$, e o erro padrão dos escores dos fatores é elevado $\left(S E_{f m}=\right.$ 
$0,447)$. Desta forma, os resultados devem ser interpretados com cautela, por tratar-se de fator ainda incipiente.

A distribuição do Q-Sort protótipo que define o Fator III é:

\begin{tabular}{lllllllll}
-4 & -3 & -2 & -1 & 0 & +1 & +2 & +3 & +4 \\
\hline 3 & 16 & 12 & 6 & 4 & 7 & 1 & 5 & 19 \\
4 & 20 & 13 & 8 & 10 & 18 & 26 & 31 & 22 \\
35 & 24 & 15 & 9 & 11 & 25 & 28 & 33 & 29 \\
& & 34 & 23 & 14 & 27 & 30 & & \\
& & & 36 & 17 & 32 & & & \\
& & & & 21 & & & &
\end{tabular}

As assertivas que representam o Fator III estão listadas abaixo, sendo marcadas com um asterisco aquelas que o distinguem dos outros fatores em nível de significância $P<0,01$ :

\begin{tabular}{|c|c|c|c|c|c|}
\hline & \multicolumn{4}{|c|}{ Fatores } \\
\hline & & I & II & III & IV \\
\hline $\mathrm{N}^{\circ}$ & Assertiva & \multicolumn{2}{|c|}{ Escores dos } & \multicolumn{2}{|c|}{ fatores } \\
\hline 19 & A gente flca mals proxima da familia. Dão mais.. amor & 1 & 0 & 4 & 2 \\
\hline 22 & Na hora de transar é bom, depois a gente paga & -2 & 1 & 4 & -2 \\
\hline$\star \star 29$ & Logo que o nenem nasce..maior atencão... Depois & -3 & -2 & 4 & -3 \\
\hline 2 & Às vezes dá medo, uma tristeza, vontade de chorar & -1 & 4 & -4 & -3 \\
\hline & Se a gente tem filho e porque Deus quis & 7 & 1 & -4 & 1 \\
\hline 35 & Ficam olhando como se a gente não fosse normal & -3 & -1 & -4 & -3 \\
\hline ** 5 & o corpo muda muito, não volta mais não & 0 & -3 & 3 & -1 \\
\hline 31 & E bom ficar com o neném, ensinar, ver ele crescer & 4 & 1 & 3 & \\
\hline 33 & Ser màe não é tão difícil.. depois pega o jeito & 2 & 3 & 3 & 3 \\
\hline 16 & Ter filho tão cedo é perder o melhor da juventude & -3 & 2 & -3 & -2 \\
\hline 20 & Às vezes dá vontade de sumır....pra me segurar & -4 & 4 & -3 & -2 \\
\hline 24 & E bom ter logo outro filho, pra fazer companhia & -2 & -4 & -3 & 1 \\
\hline
\end{tabular}

A assertiva abaixo, mesmo com baixo z-escore (entre parênteses), também distingue o Fator III dos outros fatores, com significância estatística - $P<0,05$ :

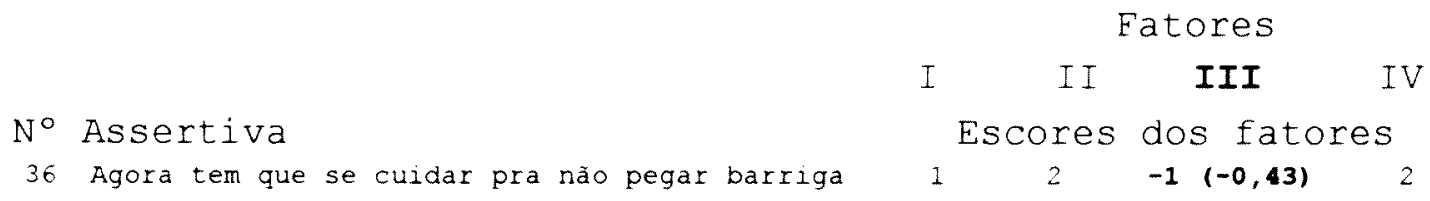

A adolescente que se define no Fator III parece vivenciar a maternidade de 
forma positiva (\# 31, 2) como uma experiência que traz maior aproximação e atenção do núcleo social (familia), que os aceita (mãe e filho) e acolhe (\#19, $35,29)$; ressente-se da diminuição da atenção familiar que ocorre após os primeiros meses após o nascimento do bebê (\# 29). Assume as conseqüências da sua vida sexual (maternidade) com certa culpa (\#22), mas sem arrependimentos, talvez com certa intencionalidade (\# 3). As perdas não são muito importantes (o corpo muda, mas a juventude permanece), não há fragilidade nem depressão (\# 5, 16, 20), mas outra gravidez não é desejada (\# 24). Não percebe o papel de mãe como um desafio ou dificuldade e tem experiências positivas no contato com seu filho (\# 33, 31). As relações da adolescente com seu núcleo familiar/social e seu filho constituem o centro da sua experiência na maternidade. Independência, planos e preocupações com o futuro não estão representados (\# 11, 17).

JSB voltou a estudar e, na entrevista (assim como ASL - mixed loader), referiu que sua vida hoje é melhor do que antes da gravidez, com ganhos importantes, inclusive de liberdade.

Em comparação com os outros grupos, é a que parece menos se preocupar com a contracepção, embora outro filho não seja desejado $(\# 36,24)$. O fato de JSB não ter vida sexual no momento (não mora com o pai da criança, não tem namorado e não faz uso de MAC) talvez justifique esta despreocupação.

Para fins de discussão, a adolescente que define o Fator III será denominada Adaptada / Dependente da família. 


\subsubsection{O Fator IV:}

Assim como o Fator III, o Fator IV é definido por somente um Q-Sort (NVG), e responde por $8,0 \%$ da variância total. A confiabilidade do Fator IV está assim prejudicada $\left(r_{x x}=0,800\right)$, e o erro padrão dos escores dos fatores é elevado $\left(S E_{\mathrm{fm}}=0,447\right)$. Desta forma, os resultados devem ser interpretados com cautela.

A distribuição do Q-Sort protótipo que caracteriza o Fator IV é:

\begin{tabular}{lllllllll}
-4 & -3 & -2 & -1 & 0 & +1 & +2 & +3 & +4 \\
\hline 12 & 2 & 16 & 1 & 7 & 3 & 14 & 30 & 10 \\
15 & 29 & 20 & 5 & 11 & 4 & 19 & 33 & 13 \\
21 & 35 & 22 & 8 & 18 & 6 & 32 & 34 & 27 \\
& & 28 & 9 & 25 & 17 & 36 & & \\
& & & 23 & 26 & 24 & & & \\
& & & & 31 & & & &
\end{tabular}

Abaixo estão descritas as assertivas que representam o Fator IV, sendo marcadas com um asterisco aquelas que o distinguem dos outros fatores em nivel de significância $P<0,05$ e com dois asteriscos quando o nível de significância é $P<0,01$ :

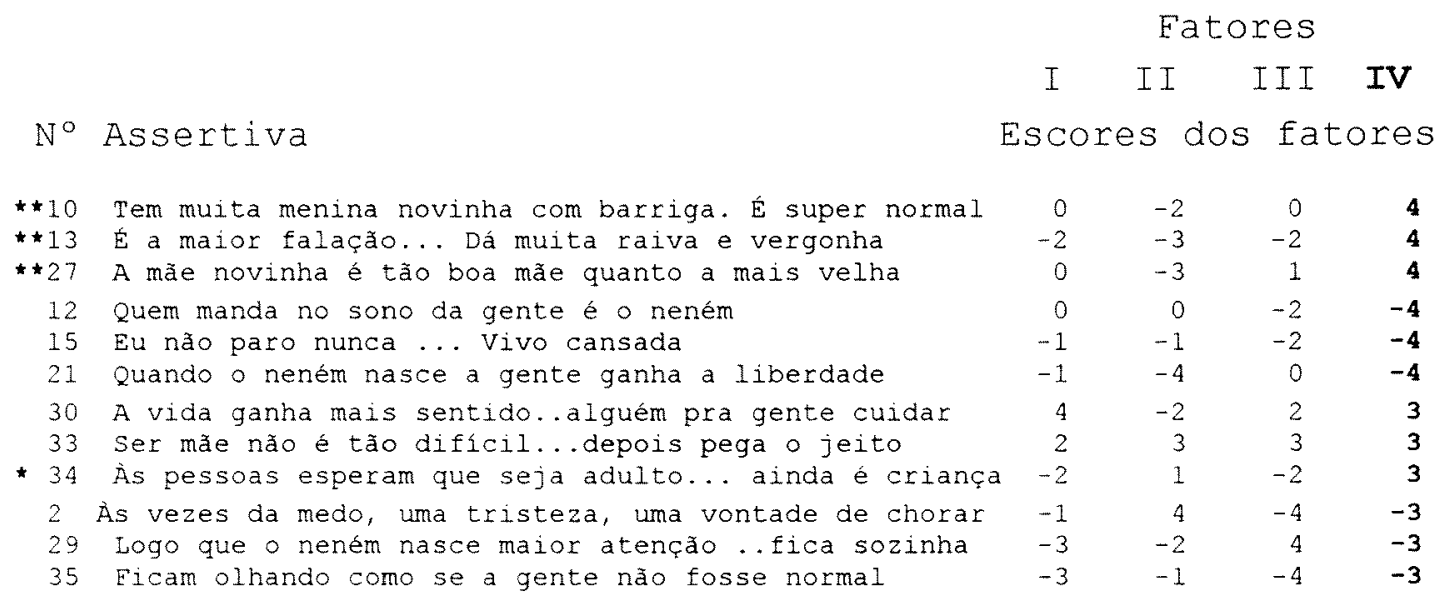

A assertiva abaixo, mesmo com baixo z-escore (entre parênteses), também 
distingue o Fator IV dos outros fatores, com significância estatistica $P<0,01$ :

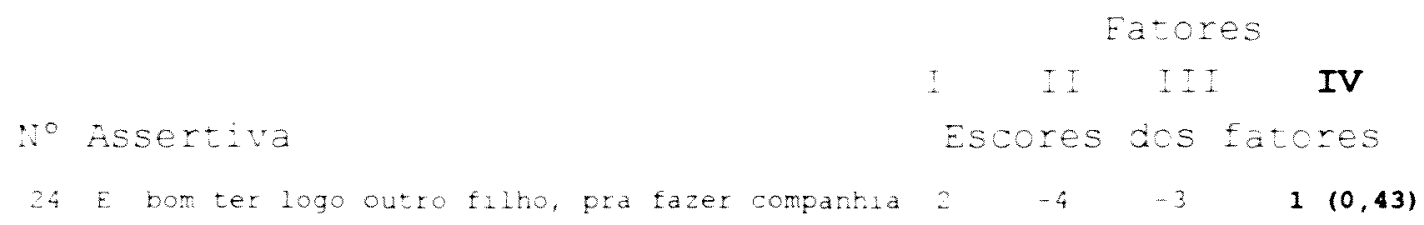

A adolescente que define este fator vivencia a maternidade como uma experiência normal, comum às jovens de sua idade (\#10,35), nem sempre aceita pelo meio adulto (\# 13). A maternidade traz um sentido à vida, com um objeto de cuidado (\# 30), mas ser mãe pode significar perda de liberdade (\# 21). O papel de mãe pode ser desempenhado sem maiores dificuldades ou sacrifícios (\# 33,12,15), tão bem pela jovem mãe como pelas mães adultas (\#27), mas a relação afetiva com o filho não se mostra relevante (\# $25,26,31$ ). Não há medo ou solidão (\# 2), mas revela sua insegurança em enfrentar esta nova fase da vida, ainda se sentindo uma criança (apesar da expectativa dos outros), sem receber o apoio que necessita (\#34, 29). As preocupações com o futuro e a busca de independência não estão representadas neste fator (\#17,11, 18). No Fator IV, a adolescente se mostra imatura, voltada para a aceitação pelo meio social

Comparando com os outros fatores, neste fator a perspectiva de uma nova gravidez é mais aceita (\# 24).

Embora coabitem o mesmo domicilio, NVG e sua mãe não se falam há meses; NVG não está estudando, tem vida sexual e faz uso de contracepção. Na entrevista, relatou que sua vida hoje é pior do que antes da gravidez, embora tenha mais liberdade. 
A adolescente que define este fator será denominada Contraditória / Em busca de identidade e apoio.

\subsubsection{Consenso:}

As assertivas que não definiram nenhum fator em particular (sem diferenças significativas) sugerem atitudes comuns aos quatro fatores. São elas:

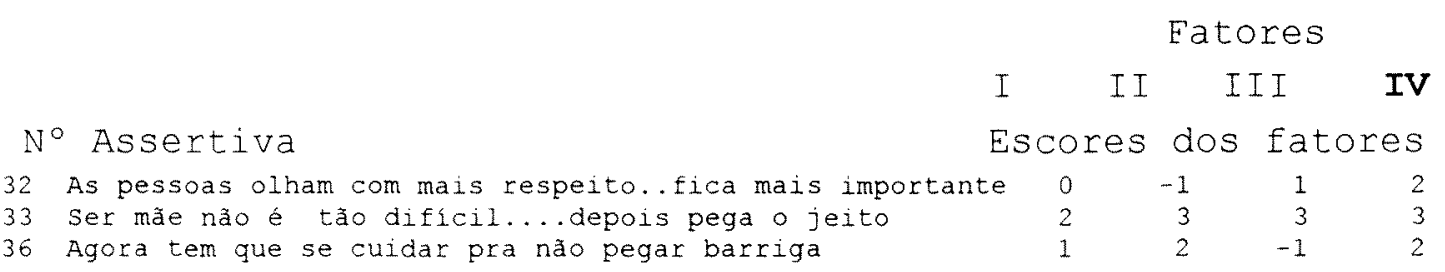

Observa-se que em todos os fatores o desempenho do papel de mãe parece ser encarado como um desafio facilmente vencido com o tempo. O poder que a maternidade confere e os cuidados futuros de contracepção suscitam atitudes relativamente neutras. 


\section{DISCUSSÃO:}

Com base no estudo de 20 jovens mães adolescentes, foram identificados pelo menos dois padrões diferentes de percepções, opiniões e atitudes frente à experiência da maternidade, atingindo os objetivos desta investigação. Estes padrões foram identificados a partir da subjetividade da adolescente, do seu próprio ponto de vista e de suas circunstâncias de vida e revelam uma heterogeneidade importante e ainda pouco explorada.

Os resultados do estudo ampliam e aprofundam a visão a respeito de um tema que, em geral, é estudado de forma fragmentada, reducionista e artificial. Esta abordagem mais "holística" e integrada se torna possivel uma vez que as variáveis são consideradas ao mesmo tempo, de forma dinâmica e relacional, através de suas interações e transformações, e não de forma isolada e linear. A abordagem "natural" se dá a partir de um contexto de significado que traz diretamente, com pouca interferência do observador, o relato da vivência da própria mãe adolescente e de suas circunstâncias de vida, biológicas, sociais, emocionais etc, todas tomadas em conjunto.

Ao contrário da visão hegemônica da sociedade e da Saúde Pública em geral, que considera os adolescentes como um bloco único, instável, sindrômico e em conflito, e a gravidez na adolescência como uma epidemia em franca ascensão, situação de risco biológico, social e emocional, indesejada, indesejável e fruto de circunstâncias de vida caracterizadas por falta de opções, os resultados deste estudo sugerem que existem diferentes 
vivências da maternidade e que, pelo menos para um grupo de jovens mães, a maternidade não é um problema, mas uma experiência de vida plena de significados positivos.

Assim, o primeiro padrão identificado (Satisfeita com a maternidade / Dependente do afeto do filho) revela um contentamento geral, auto-estima, confiança e uma visão positiva da vida, como se pode deduzir pela assertiva 4, que bem retrata o Fator 1 :

\# 4. Ter um filho é a melhor coisa que pode acontecer na vida da gente. $(+4)$

O segundo padrão (Deprimida / Estressada) expõe fragilidade, descontentamento e uma visão negativa da vida, situação caracterizada pelas assertivas 2 e 20 :

\# 2. Às vezes dá um medo, uma tristeza, uma vontade de chorar. (+4) \# 20. Às vezes me dá uma vontade de pegar o menino e sumir. Não vai ser homem ou familia pra me segurar. (+4)

Os outros dois fatores: Adaptada / Dependente da família (Fator III) e Contraditória / Em busca de identidade e apoio (Fator IV) são definidos basicamente por uma adolescente cada e necessitam confirmação em estudo subseqüente. São caracterizados respectivamente pelas assertivas 19 e 10 
Fator III:

\# 19. A gente fica mais próxima da familia. Dão mais carinho e amor.

Fator IV:

\# 10. Tem muita menina novinha com barriga. É super normal.

Os fatores II e IV parecem retratar as adolescentes/mães como as adolescentes que constituem o padrão descrito pela sociedade em geral e que são alvo das ações dos programas de saúde

\subsection{LIMITAÇŌES DOS RESULTADOS:}

\subsubsection{O tamanho da amostra:}

Na Metodologia Q, o tamanho da amostra não é uma questão tão fundamental quanto nos estudos quantitativos. No entanto, o número de sujeitos estudados é elemento importante para o cálculo da confiabilidade do fator (McKEOWN e THOMAS 1988; BROWN 1980). Neste estudo, 20 respostas foram suficientes para mostrar dois padrões qualitativa e estatisticamente diferentes de vivências da maternidade na adolescência precoce. Para que a existência de outros fatores com elevada confiabilidade pudesse ser confirmada, seria necessária uma amostra maior do que a obtida neste estudo. Na Metodologia $Q$, esta informação só é obtida a posteriori, após a análise dos dados, diferentemente dos métodos quantitativos mais tradicionais, em que o tamanho amostral é calculado na fase de elaboração do projeto, a partir do erro estimado. 
A captação de mães adolescentes elegiveis para esta pesquisa nas unidades de saúde selecionadas foi difícil, e foram necessárias inúmeras visitas aos serviços de saúde materno-infantil para que ao menos uma adolescente fosse identificada. Algumas hipóteses são levantadas para explicar as dificuldades:

- não existem registros informatizados com dados sobre os usuários, e, assim, os profissionais de saúde supervalorizariam a freqüência do atendimento a jovens mães. Existem poucas mães adolescentes entre 11 e 16 anos de idade, ou seja, o número absoluto é pequeno. Em 1996, em todo o Município do Rio de Janeiro, dos 91691 nascidos vivos, 795 eram filhos de adolescentes de 10 a 14 anos de idade, correspondendo a 0,87\% do total de nascidos vivos (MINISTÉRIO DA SAÚDE DO BRASIL 1998). No entanto, a cada ano este número cresce, tanto em termos absolutos quanto relativos, e o evento parece ser tão marcante para os profissionais de saúde, que estes incorreriam em viés de memória

- a quase totalidade dos serviços de saúde materno-infantil não se organiza para uma assistência especifica à mãe adolescente e seu filho, com dias e horários específicos, e, assim, estas jovens mães, em pequeno número absoluto, ficam dispersas dentro do atendimento pediátrico geral.

- a jovem mãe procuraria menos os serviços de acompanhamento pediátrico do que as outras mães. Embora existam evidências de que não haja diferença entre o comportamento de mães adolescentes e de 
mães adultas na procura de serviços de saúde para seus filhos (BRINK e col. 1985; BUCHHOLZ e GOL 1986), não existem dados que abordem esta questão específica em nosso meio, até onde foi possível pesquisar.

Tais obstáculos podem ter contribuído para as dificuldades encontradas, impossibilitando a inclusão de maior número de mães adolescentes no periodo previsto para a realização da pesquisa.

Desta forma, os Fatores III e IV devem ser considerados como resultados incipientes, a serem melhor estudados com uma amostra maior de mães adolescentes, até que haja uma saturação dos fatores identificados.

\subsubsection{A Composição da amostra:}

A amostra foi composta por mães que são atendidas regularmente em serviços públicos de saúde materno-infantil. As adolescentes que não procuram ou não são captadas pelas unidades de saúde a nível ambulatorial ou as que não comparecem às consultas agendadas não estão representadas e podem definir fatores diferentes daqueles explorados neste estudo. Da mesma forma, mães adolescentes que utilizam serviços privados ou conveniados com as grandes empresas seguradoras de saúde podem expressar suas vivências de forma diferente, uma vez que suas circunstâncias de vida são provavelmente muito diversas daquelas do grupo estudado. Os resultados, assim, dizem respeito ao grupo de mães adolescentes usuárias dos serviços públicos de saúde materno-infantil. 


\subsection{QUESTÓES RELACIONADAS COM A VALIDADE E A CONFIABILIDADE:}

Na Metodologia $Q$, a questão da validade de um estudo baseia-se no fato de que os dados são "naturais" (auto-referentes, a partir do padrão de referência do observado) e a interferência do pesquisador é pequena, tanto na coleta (o processo do Q-sorting realizado pelo próprio sujeito do estudo) quanto na análise dos resultados [análise fatorial, limitando o viés do observador] (BROWN 1980; McKEOWN e THOMAS 1988).

Para que a possibilidade de ocorrência de viéses na obtenção do concourse of ideas, na seleção do Q-sample e na coleta de dados fosse minimizada, os seguintes procedimentos metodológicos foram adotados neste estudo:

- na obtenção do concourse of ideas: para que a lista de opiniões e idéias a respeito da maternidade na adolescência fosse ampla, diversa e abrangente, representando o fluxo corrente de comunicação, foram utilizadas estratégias diversas de busca de idéias, até a saturação. Para tal, procedeu-se ao desenvolvimento de quatro grupos focais com adolescentes e não adolescentes, consultou-se a literatura e a mídia. A linguagem coloquial das adolescentes foi cuidadosamente reproduzida.

- na seleção do Q-sample: para que a amostra representasse as principais idéias e opiniões encontradas no concourse of ideas de forma balanceada sem hipo ou hiper representação de alguns componentes, montou-se uma amostragem estruturada, com três categorias de significado, buscando-se aliar variedade com entendimento e facilidade 
de procedimentos. O processo de identificação das categorias de significado e de seleção das assertivas foi discutido com observador independente, familiarizado com a Metodologia Q.

- a condição de instrução foi simples, objetiva e dirigida ao momento de vida presente da respondente.

A adequação dos dados à análise fatorial foi limitada $(K M O=0,59)$, porém possivel (BTS com significância $<0,01$ ), e os resultados explicam $65 \%$ do fenômeno estudado.

Na Metodologia Q não é possível (e nem se pretende) fazer qualquer generalização em termos de características populacionais ou inferência quanto à prevalência dos fatores identificados na população geral. No entanto, os fatores por si só já representam generalizações de determinada forma de pensar. Nenhuma adolescente do estudo distribuiu suas assertivas exatamente como definido num determinado fator. $O$ fator representa sobretudo a generalização da maneira como as jovens mães que o definiram pensavam / sentiam quando estimuladas pela pergunta do pesquisador e pelas opções apresentadas.

Conforme citado na Introdução deste estudo, a literatura sobre o tema especifico da maternidade na adolescência é restrita, contraditória e centrada no estudo de adolescentes com idade até 19 anos. Muitas investigações partem de categorias pré-concebidas e descrevem seus resultados sob a forma de medidas de freqüências de variáveis isoladas, tais 
como estresse, depressão, fracasso escolar, etc (REIS 1989; BARNET e col. 1996; TETI e LAMB 1989). Estas diferenças metodológicas dificultam ou mesmo impossibilitam a comparação com os resultados obtidos neste estudo. Já as poucas pesquisas de enfoque mais qualitativo são mais adequadas para a triangulação, com verificação da confiabilidade e melhor compreensão dos resultados, conforme a análise subseqüente.

A percepção da gravidez e da maternidade de forma positiva, com aumento da auto-estima, como explicado no Fator I, foi também identificada por outros autores (MERCER 1980; ARENSON 1994; PAIVA e col.1998; OLIVEIRA 1999). A busca de estabilidade e permanência, revelada através da percepção do filho como propriedade, poderia traduzir uma tentativa de obter autonomia e atingir a maturidade, assim como a percepção da própria competência para dar conta das tarefas junto ao bebê (ARENSON 1994; PAIVA e col.1998; SCIARRA e PONTEROTTO 1998).

A aparente contradição entre a interpretação do Fator I (vivência positiva da maternidade) e algumas respostas quanto à qualidade de vida atual (pior do que antes da gravidez), como observado nas adolescentes RRC1, RRC2, WSS,ACF, VMC, CST, DVM, JCPN e ICF, pode ser explicada pela diferença do método de coleta de dados (Q-sorts X entrevista). Na Metodologia Q, o sentido de cada assertiva é relativizado frente às outras opções e busca-se uma percepção global das circunstâncias de vida do sujeito estudado. Em geral, esta complexidade não é captada por métodos de abordagem mais diretos. No entanto, observa-se que todas as adolescentes que 
apresentaram respostas diretas positivas: vida atual melhor ou igual (RSG, LRB, APS, ASL, DA e JSB) estão agrupadas nos Fatores I e III (fatores com visão mais positiva da maternidade).

A depressão, o estresse e a percepção predominante dos aspectos negativos e das perdas conseqüentes à maternidade são os elementos de significado do Fator II e foram também identificados em outros estudos (MERCER 1980; MERCER 1985; BARNET e col. 1996). A falta de suporte social (principalmente da mãe da adolescente e do companheiro), ou sua presença conflituosa, é considerada fonte importante de estresse (BARNET e col. 1996).

O Fator III expressa uma aparente contradição entre a busca de independência e de identidade (características da adolescência) e a busca de estabilidade e equilíbrio nas relações familiares (possibilitada pela maternidade, particularmente em familias em conflito). Esta situação também é descrita por outros autores (BUCHHOLZ e GOL 1986). Desta forma, paradoxalmente, a maternidade acarreta maior dependência e cumplicidade entre a adolescente e sua família, particularmente sua mãe (MERCER 1980; SCIARRA e PONTEROTTO 1998).

O Fator IV expressa o conflito entre a presença cada vez mais frequente ("normal") da mãe adolescente no meio social urbano carente e a dificuldade de sua aceitação pelo grupo social mais extenso, que se reflete através de comentários e críticas de familiares, amigos e vizinhos. Estes aspectos também são abordados em outros estudos (MERCER 1980; PAIVA e col. 
1998). A frágil autoconfiança da adolescente pode ser ameaçada por esta discriminação do grupo social, gerando sentimentos de raiva e de defesa.

Em concordância com os dados da literatura, é consenso em todos os fatores que a maternidade é uma experiência difícil, que demanda muita responsabilidade, mas que pode ser desempenhada a contento pela mãe adolescente (MERCER 1980; Ellerbee 1990 citada por THOMPSON e col. 1995, p. 714)

Em síntese, esta pesquisa é exploratória em sua natureza e inovadora em muitos aspectos:

- na escolha do tema - a maternidade na adolescência, em contraposição à gravidez na adolescência;

- nos sujeitos de estudo - a mãe adolescente, grávida dos 10 aos 14 anos de idade, em contraposição à adolescente maior (de 15 a 19 anos);

- na hipótese que inspira o estudo- o significado da maternidade não é unico, em contraposição à hipótese de uma atitude homogênea;

- na metodologia utilizada - a Metodologia $Q$, inédita no campo da Saúde Pública em nosso meio. Voltada para o estudo da subjetividade em termos de comportamento comunicável e auto-referente, $Q$ incorpora métodos qualitativos e quantitativos de coleta e análise de dados, em contraposição ao uso de questionários que partem de definições operacionais prévias e tendem a colocar o sujeito dentro dos limites da estrutura conceitual do observador.

Embora de caráter exploratório, este estudo se inspira na hipótese de que 
entre mães adolescentes existem diferentes padrões de opiniões e atitudes frente à maternidade. Desta forma, sob a hipótese nula, os resultados deste estudo apontariam para a identificação de um único fator, que refletiria um único padrão de atitudes. Uma vez que os resultados apontam para uma situação de comunicação muiti-dimensional, podemos rejeitar a hipótese nula.

A partir da subjetividade de 20 jovens mães, foi possivel revelar a existência de pelo menos duas estruturas diferentes de pensamento quanto à experiência da maternidade, sem a interferência do observador e sem categorização a priori. Alguns padrões mostraram-se semelhantes aos descritos pela literatura estudando adolescentes mais velhas (de 15 a 19 anos), inclusive as experiências de vida positivas, negativas e as situações de conflito.

Os resultados deste estudo podem, assim, contribuir não somente para um melhor entendimento das circunstâncias de vida de jovens mães que freqüentam os serviços públicos de saúde em nosso meio, como possibilitar que os profissionais de saúde planejem e executem intervenções mais adequadas e eficientes.

A Metodologia $Q$ vem, então, representar mais uma ferramenta metodológica válida, elegante e lúdica, a ser colocada à disposição do pesquisador da área da saúde em nosso meio, ampliando suas possibilidades de conhecer a realidade que o cerca e de contribuir para a melhoria das condições de vida e saúde da população. 


\section{CONCLUSÕES:}

Através do uso de uma metodologia ainda pouco conhecida em nosso meio, a Metodologia $Q$, foi possivel concluir que a vivência da maternidade na adolescência precoce não é única nem homogênea, e diferentes padrões de opiniões e percepções foram identificados entre adolescentes que ficaram grávidas entre 10 e 14 anos de idade.

Dois fatores foram bem definidos: Fator I - Satisfeita com a maternidade I Dependente do afeto do filho: a maternidade como uma vivência positiva e enriquecedora e Fator II - Deprimidal Estressada: visão negativa e exploração adicional em estudo subseqüente, com amostra mais numerosa: Fator III - Adaptada / Dependente da família: a maternidade como experiência positiva de estreitamento de vínculos familiares; e Fator IV Contraditória / Em busca de identidade e apoio: vivência em conflito com os valores sociais.

Estas diferentes circunstâncias de vida puderam ser identificadas a partir de um contexto de vida subjetivo, global, integrado e dinâmico, sem a fragmentação e distanciamento característicos dos estudos de enfoque mais biomédico.

Os achados deste estudo podem contribuir para o re-exame das crenças e idéias pré-concebidas a respeito da maternidade na adolescência, assim como para aumentar o entendimento a respeito da diversidade, das dificuldades que enfrentam e do potencial das mães adolescentes. Desta 
forma, poderá favorecer uma postura mais ética de respeito ao jovem, aberta às inúmeras possibilidades do ser humano, promovendo atividades menos coercitivas, com aceitação, respeito e diálogo. 


\section{CONSIDERAÇÕES FINAIS}




\section{CONSIDERAGOESFNAS:}

Observa-se que pelo menos um grupo de jovens mães expressa uma vivência bastante positiva da maternidade, em contraste com o discurso tradicional e com as ações preconizadas pela Saúde Pública a respeito da gravidez/maternidade na adolescência. A postura crítica assumida neste trabalho em relação a estas idéias não significa que a maternidade na adolescência seja aceita pela autora como uma boa ou melhor opção para a adolescente. A pesquisadora acredita que os indivíduos, incluindo os adolescentes, têm o direito ao bem-estar e ao pleno desenvolvimento de suas capacidades; que é necessário estabelecer condições de vida adequadas para todos; e que esta responsabilidade não deve ser assumida somente pelo Setor Saúde. Reconhece também como legítimas muitas das preocupações da sociedade em geral em relação à saúde da adolescente e seu filho. No entanto, entende que a concepção negativa, moralista e reducionista sobre o "problema da gravidez / maternidade na adolescência" tende a construir limitações e implicações éticas no desenvolvimento de pesquisas e na atuação dos profissionais junto aos adolescentes.

Desta forma, a partir dos dados da literatura, dos resultados deste estudo e de sua própria experiência e considerando que desempenha suas atividades profissionais em instituições de ensino superior na área médica, onde o tripé ensino/pesquisa/extensão não deve ser dissociado, a autora propõe os seguintes caminhos a serem trilhados: 


\subsection{EM RELACGAO A PESQUISA:}

O desenvolvimento de investigações voltadas para:

- explorar a existência de outros fatores além dos Fatores I e II (aumentando a amostra); confirmar ou não os Fatores III e IV;

- acompanhar e comparar a mudança das percepções dessas adolescentes e a evolução de seus filhos, repetindo o estudo em outros momentos (aos dois e cinco anos de idade, por exemplo); observar em particular a evolução das adolescentes que definem o Fator II (Deprimida/Estressada) e de seus bebês;

- estudar os mesmos aspectos em mães adolescentes até 19 anos;

- explorar as opiniões de jovens adolescentes grávidas a respeito do que pensam ser a maternidade; acompanhar essas jovens após o nascimento do bebê, repetindo o estímulo em períodos determinados e comparando os resultados;

- explorar e comparar as opiniões de planejadores de saúde, profissionais diretamente envolvidos na assistência à saúde do adolescente, familiares da adolescente (sua mãe, companheiro), adolescentes não grávidas etc., a respeito do que pensam ser a vivência da maternidade na adolescência;

- estimar a prevalência dos fatores identificados numa amostra representativa, utilizando questionários ou escalas (tipo Likert) 
construidos a partir das assertivas definidoras dos extremos dos factor arrays etc.

\subsection{EM RELAÇÃO A ASSISTÉNCIA A SAÚDE:}

Na assistência direta (no IPPMG e na UISHL):

- contactar as adolescentes que definem os Fatores II e IV e avaliar a necessidade de intervenções imediatas, através de uma abordagem multidisciplinar.

No planejamento de ações de saúde:

No nivel local (no IPPMG):

- propor à equipe de saúde do Ambulatório Materno-Infantil e à administração da unidade a implementação de um programa multidisciplinar voltado para a assistência à mãe adolescente e seu filho, semelhante ao já implementado na UISHL, em continuidade ao programa de atenção à adolescente grávida, já desenvolvido no pré-natal do IPPMG;

- ampliar o entendimento dos profissionais envolvidos na atenção maternoinfantil a respeito dos possiveis cursos de vida das mães adolescentes, inclusive os mais positivos, propondo uma reavaliação das crenças e idéias a respeito deste grupo. Espera-se que profissionais mais receptivos às múltiplas facetas da maternidade na adolescência e mais sensíveis aos pontos de vista do "outro" aceitem e interajam melhor com 
as jovens mães e suas familias, na medida em que reconhecem e respeitam a sua individualidade.

No nivel geral:

- divulgar os conhecimentos existentes a respeito da complexidade da maternidade na adolescência precoce nas diversas instâncias acadêmicas, profissionais e da sociedade civil em geral, proporcionando assim uma oportunidade de reflexão e desestigmatização da mãe adolescente;

- propor a inserção e aplicação destes conhecimentos nos programas dirigidos à atenção à criança e ao adolescente, melhor qualificando as ações e intervenções voltadas para as necessidades e especificidades da jovem mãe e sem "pré-conceituar" a maternidade como simplesmente um evento negativo e indesejável.

Na educação de profissionais de saúde (graduação, pós-graduação etc.):

- propor que os currículos dos diversos cursos voltados para a atenção à criança e ao adolescente relativizem o enfoque biomédico e incluam os diversos aspectos da maternidade na adolescência (inclusive os positivos), enfatizando a heterogeneidade deste grupo;

- enfatizar os métodos de aprendizado voltados para o desenvolvimento de habilidades de empatia e comunicação com a mãe adolescente e sua familia, possibilitando melhor identificação de suas particularidades e resposta às suas necessidades. 
REFERÊNCIAS 


\section{REFERÊNCIAS:}

1. [IBGE] Fundação Instituto Brasileiro de Geografia e Estatística.

Estimativa para a população de 2001 [acesso on line] 2000. Disponivel em <URL: http://www.ibge.gov.br/> [2001 March 30].

2. [OMS] Organización Mundial de la Salud. Higiene de la reproduccion en la adolescencia. Estrategia de acción; declaracción conjunta. OMS/FNUAP/UNICEF. Genebra, 1989.

3. [OMS] Organización Mundial de la Salud. Conclusiones y recomendaciones de las discusiones técnicas sobre la salud de los jóvens de la 42a Asemblea Mundial de la Salud. Ginebra; 1989.

4. [OPAS] Organización Panamericana de la Salud. La situación de salud del adolescente en América Latina - base para un plan de acción regional. Washington, DC; 1987.

5. [OPAS] Organización Panamericana de la Salud. O marco conceptual da saúde integral do adolescente e de seu cuidado. Washington, DC; 1990.

6. [WHO] World Health Organization. Meeting on pregnancy and abortion in adolescence. Geneva, 1974. Report. Geneva; 1975. (WHO Technical Report Series, 583).

7. Alegria FVL, Schor N, Siqueira AAF. Gravidez na adolescência: estudo comparativo. Rev Saúde Pública 1989; 23(6): 473-7. 
8. Amini SB, Catalano PM, Dierker LJ, Mann LI. Births to teenagers: trends and obstetric outcomes. Obstetr Gynecol 1996; 87(5Pt1): 668-74.

9. Arenson JD. Strengths and self-perceptions of parenting in adolescent mothers. J Ped Nurs 1994; 9(4): 251-7

10. Ariès $P$. História social da criança e da familia. Rio de Janeiro: Guanabara Koogan; 1981.

11. Atkinson J. PQMethod [computer software]. Version 2.0, Kent: Kent State University, Computer Center; 1992. Versão 2.09 adaptada por Peter Schmolck.

12. Ayres JRCM. Adolescência e saúde coletiva: aspectos epistemológicos da abordagem programática. In: Schaiber LB, organizadora. Programação em saúde hoje. $2^{a}$ ed. São Paulo: HUCITEC; 1993. p. 139-82. (Saúde em Debate 30).

13. Baranowski MD, Schilmoeller GL, Higgins BS. Parenting attitudes of adolescent and older mothers. Adolescence 1990; 25(100): 781-90.

14. Barbosa JC, Willoughby P, Rosenberg CA, Mrtek RG. Statistical methodology: VII. Q-Methodology, a structural analytic approach to medical subjectivity. Acad Emerg Med 1998; 5(10): 1032-40

15. Barnet B, Joffe A, Duggan AK, Wilson MD, Repke JT. Depressive symptoms, stress, and social support in pregnant and postpartum adolescents. Arch Ped Adolesc Med 1996; 150(1): 64-9.

16. Becker D. O que é adolescência. São Paulo: Brasiliense; 1985. 
17. Boulton MG. On being a mother. London: Tavistock Publications; 1983.

18. Branco VMC. Gravidez na adolescência: problema para quem? Interação 1997; Jan/Mar: 6-7

19. Brink S, Martin R, Golden D, Smith L. Primary pediatric care. A comparison of use by adolescent and older mothers. J Adolesc Health Care 1985; 6(3): 201-5.

20. Brown SR. Political subjectivity. New Haven: Yale University Press; 1980.

21. Brown SR. Imagery, mood and the public expression of opinion. Micropolitics 1982; 2: 152-73.

22. Brown SR. Q technique and method: principles and procedures. In: Berry WD, Lewis-Beck MS, editors. New tools for social scientists: advances and applications in research methods. Beverly Hills: Sage University Press; 1986. p. 57-76.

23. Buchholz ES, Gol B. More than playing house: A developmental perspective on the strengths in teenage motherhood. Amer $\mathrm{J}$ Orthopsychiat $1986 ; 56(3)$ : 347-59.

24. Camp BW. Maternal characteristics of adolescent mothers and older mothers of infants. Psychol Reports 1995; 77(3 Pt 2): 1152-4. 
25. Castro Moura JV. Gravidez na adolescência: estudo retrospectivo nos anos de 1978, 1982 e 1987 na Santa Casa de Misericórdia de Pindamonhangaba. São Paulo; 1991. [Dissertação de Mestrado Faculdade de Saúde Pública da USP].

26. Castro Moura JV. Discurso de jovens grávidas: uma abordagem fenomenológico-hermenêutica à luz de Heidegger. São Paulo; 1996. [Tese de Doutorado - Faculdade de Saúde Pública da USP].

27. Cavalcanti RC. Adolescência. In: Vitiello $\mathrm{N}$ et al., editores. Adolescência hoje. São Paulo: Roca; 1988. p.5-27.

28. Colli AS, Deluqqui CG. Adolescência. In: Alcântara P, Marcondes E, editores. Pediatria Básica. $6^{\circ}$ ed. São Paulo: Sarvier; 1978. p.175.

29. Cooper LG, Leland NL, Alexander G. Effect of maternal age on birth outcomes among young adolescents. Soc Biol 1995; 42(1-2): 22-35.

30. Costa MCO. Fecundidade na adolescência: perspectiva histórica e atual. J Pediatr 1998; 74(2): 87-90.

31. Cunha AA, Monteiro DLM, Reis AFF. Fatores de risco da gravidez na adolescência. In: Monteiro DLM, Cunha AA, Bastos AC, editores. Gravidez na adolescência. Rio de Janeiro: Livraria e Editora REVINTER Ltda; 1998. p.43-56 
32. Cunha AA, Monteiro DLM. Gravidez na adolescência como problema de saúde pública. In: Monteiro DLM, Cunha AA, Bastos AC, editores. Gravidez na adolescência. Rio de Janeiro: Livraria e Editora REVINTER Ltda; 1998. p.31-42.

33. Dennis KE, Goldberg AP. Weight control self efficacy types and transitions affect weight loss outcomes in obese women. Addict Behav 1996; 21: 102-16.

34. Domingues Jr. JS. Utilização de métodos contraceptivos na adolescência: uma opção?. São Paulo; 1998. [Dissertação de Mestrado - Faculdade de Saúde Pública da USP].

35. East PL, Matthews KL, Felice ME. Qualities of adolescent mothers' parenting. J Adolesc Health 1994; 15(2):163-8

36. Elster AB, McAnarney ER, Lamb ME. Parental behavior of adolescent mothers. Pediatrics 1983; 71(4): 494-503.

37. Fagim IG, Matos HJ, Cunha AA. Filhos de mães adolescentes. In: Monteiro DLM, Cunha AA, Bastos AC, editores. Gravidez na adolescência. Rio de Janeiro: Livraria e Editora REVINTER Ltda; 1998. p. $121-36$

38. Finkelstein JW, Finkelstein JA, Christie M, Roden M, Shelton C. Teenage pregnancy and parenthood: Outcomes for mother and child. $\mathrm{J}$ Adolesc Health Care $1982 ; 3: 1-7$ 
39. Fraser AM, Brockert JE, Ward RH. Associations of young maternal age with adverse reproductive outcomes. NEJM 1995; 332(17): 1113-7.

40. Freyre G. Casa grande e senzala: formação da familia brasileira sob o regime de economia patriarcal. $13^{a}$ ed. Rio de Janeiro: José Olympio; 1966.

41. Fundação Getúlio Vargas. Centro de Políticas Sociais. Pobreza está em queda no Brasil, segundo a FGV. O Globo 2001 abril 17; cad Economia: 29.

42. Furtado C. Formação econômica do Brasil. $16^{a}$ ed. São Paulo: Ed. Nacional; 1979.

43. Gargan JJ, Brown SR. "What is to be done? Anticipating the future and mobilizing prudence. Policy Sciences 1993; 26: 347-59.

44. Gelula MH. Using Roland Barthe's theory of literary criticism in the analysis of Q-Methodology: a working paper [Apresentado no 13th International Conference on Subjectivity: 1997 Oct 23-25; Syracuse, EUA].

45. Grossman E. O médico de adolescente e seu ofício - reflexões sobre as normas e a prática. Rio de Janeiro;1995. [Dissertação de Mestrado Instituto Fernandes Figueira - Fundação Oswaldo Cruz, Ministério da Saúde]. 
46. Grossman E, Cardoso MHC. As bases conceituais dos documentos oficiais de atenção à saúde do adolescente. Rev bras crescimento desenvolv hum 1997; 7(2): 1-11.

47. Grosswiler P. Subjectivity or the death of the subject: $Q$ theory vs. postmodern theory. [Apresentado no 13th International Conference on Subjectivity: 1997 Oct 23-25; Syracuse, EUA].

48. Halpern R, Schaefer ES, Pereira AS, Arnt EM, Bezerra JPV, Pinto LS. Fatores de risco para baixo peso ao nascer em uma comunidade rural do sul do Brasil. J Pediatr 1996; 72(6): 369-73.

49. Haskett ME, Johnson CA, Miller JW. Individual differences in risk of child abuse by adolescent mothers: assessment in the perinatal period. J Child Psychol Psychiatry 1994; 35(3): 461-76.

50. Hayes CD. Risking the future. Adolescent sexuality, pregnancy, and childbearing. Washington: National Academy Press; 1987.

51. Hollingsworth DR, Felice M. Teeage pregnancy: a multiracial sociologic problem. Am J Obstet Gynecol 1986; 155: 742.

52. Knobel M, Perestrello M, Uchoa DM. A adolescência e a família atual. Visão psicanalitica. Rio de Janeiro: Atheneu, 1981.

53. Knobel M. Sindrome da adolescência normal. In: Aberastury A, Knobel M, editores. Adolescência normal. Um enfoque psicanalítico. $9^{\mathrm{a}}$ ed. Porto Alegre: Artes Médicas; 1981. p. 24-62. 
54. Landy S, Cleland J, Schubert J. The individuality of teenage mothers and its implication for intervention strategies. J Adolesc 1984; 7(2): 171-90,

55. Larsen JJ, Juhasz AM. The effects of knowledge of child development and social-emotional maturity on adolescent attitudes toward parenting. Adolescence $1985 ; 20(80): 823-39$

56. Larson PJ. Important nurse caring bahaviors perceived by patients with cancer. Oncol Nurs Forum 1984; 11(6): 46-50.

57. Leite MM. A condição feminina no Rio de Janeiro. Século XIX. São Paulo: HUCITEC; 1993. p. 87.

58. Lins MJSC. Um sentido para a educação sexual. O Globo, Rio de Janeiro, 1999 jul 23; cad 1:7.

59. Macklin NR. Early adolescent pregnancy: a search for meaning. Ann Arbor; 1992. [Dissertação de Doutorado - Saint Louis University].

60. Mariotoni GGB, Barros Filho AA. A gravidez na adolescência é fator de risco para o baixo peso ao nascer? J Pediatr 1998; 74(2): 107-13.

61. Marques NM, Ebrahim GJ. The antecedents of adolescent pregnancy in a Brazilian squatter community. J Trop Pediatr 1991; 37(4): 194-8.

62. McAnarney ER, Lawrence RA, Ricciuti HN, Polley J, Szilagyi M. Interactions of adolescent mothers and their 1-year-old children. Pediatrics 1986; 78(4): 785-90.

63. McKeown B, Thomas D. Q Methodology. Newbury Park: Sage Publications, 1988. 
64. McKeown BF. Q methodology in political psychology: theory and technique in psychoanalytic applications. Political Psychol 1984; 5: 41536 .

65. Medrado B, Lyra J. A adolescência "desprevenida" e a paternidade na adolescência: uma abordagem geracional e de gênero. In: Cadernos Juventude, Saúde e Desenvolvimento. Brasilia; 1999. p.230-48.

66. Mercer RT. Teenage motherhood: the first year. JOGN 1980; Jan-Feb: $16-24$

67. Mercer RT, Hackley KC, Bostrom A. Adolescent motherhood. Comparison of outcome with older mothers. J Adolesc Health Care $1984 ; 5(1): 7-13$

68. Mercer RT. The process of maternal role attainment over the first year. Nurs Research 1985; 34(4): 198-204.

69. Ministério da Saúde do Brasil. Programa de saúde do adolescente. Bases programáticas. Brasilia; 1989.

70. Ministério da Saúde do Brasil. Normas de atenção à saúde integral do adolescente. Brasília; 1993.

71. Ministério da Saúde do Brasil. SINASC - Sistema Nacional de Nascidos Vivos [acesso on line] 1994. Disponivel em <URL http://wuw.datasus.gov.br/> [1999 Oct 12] 
72. Ministério da Saúde do Brasil. Informações em saúde. Indicadores demográficos básicos para 1997. Composição populacional. Brasil 1997[acesso on line] 1997. Disponivel em <URL:

http://uww. saude.gov.br/inform/IDB97/Demog/> [2001 Jun 10].

73. Ministério da Saúde do Brasil. SINASC - Sistema Nacional de Nascidos Vivos [acesso on line] 1998. Disponivel em <URL:

http://wnw.datasus.gov.br/> [2001 March 30].

74. Monteiro CA, Benício MHA, Freitas ICM. Melhoria em indicadores de saúde associados a pobreza: descrição, causas e impacto sobre desigualdades regionais. São Paulo; 1997. (NUPENS/USP. Série : A trajetória do desenvolvimento social no Brasil, 1/97).

75. Monteiro DLM, Cunha AA, Reis AFF. Risk factors in teenagers' pregnancy. Int J Obstet Gynec 1994; 46 (Suppl 1): 88

76. Monteiro DLM, Cunha AA, Fagim IG, Paiva AS. Modelo de assistência multidisciplinar na adolescência, visando o bem estar materno-fetal e a contracepção. Reprodução \& Climatério 1995; 10(2): 67-72.

77. Monteiro DLM, Fagim IG, Paiva AS, Cunha AA. Modelo de assistência multidisciplinar à gravidez na adolescência. In: Monteiro DLM, Cunha AA, Bastos AC, editores. Gravidez na adolescência. Rio de Janeiro: Livraria e Editora REVINTER Ltda; 1998. p. 148-69.

78. Moore KA, Waite LL. Teenage mothers and teenage fathers: The impact of early childbearing on the parents' personal and professional lives. Fam Plan Persp 1977; 9(5): 221-5. 
79. Moore KA. Children of teen parents: heterogeneity of outcomes. Relatório de pesquisa. Washington, DC: NICHD; 1986.

80. Mora G. Aspectos demográficos da população adolescente brasileira. In: OPAS/OMS. Coletânea sobre saúde reprodutiva do adolescente brasileiro. Brasília, DF; 1988. p. 7-15.

81. Nord CW, Moore KA, Morrison DR., Brown B, Myers DE. Consequences of teen-age parenting. J School Health 1992; 62(7): 310-8

82. O'Sullivan AL, Jacobsen BS. A randomized trial of a health care program for first-time adolescent mothers and their infants. Nurs Research 1992; 41(4): $210-215$

83. Oliveira NR. Perfis de grávidas e mães adolescentes: estudo psicossocial de adolescentes usuárias de um serviço público de pré-natal e maternidade. São Paulo;1999. [Tese de Doutorado Instituto de Psicologia - Universidade de São Paulo].

84. Paiva AS, Caldas MLCS, Cunha AA. Perfil psicossocial da gravidez na adolescência. In: Monteiro DLM, Cunha AA, Bastos AC, editores Gravidez na adolescência. Rio de Janeiro: Livraria e Editora REVINTER Ltda; 1998. p. 7-30.

85. Panzarine S, Slater S, Sharps P. Coping, social support, and depressive symptoms in adolescent mothers. J Adolesc Health 1995; 17(2):113-9. 
86. Peres F, Rosenburg CP. Desvelando a concepção de adolescêncial adolescente presente no discurso da Saúde Pública. Saúde e Sociedade $1998 ; 7(1): 53-86$

87. Pinto e Silva JL. Contribuição ao estudo da gravidez na adolescência. Campinas; 1982. [Tese de Doutorado - Faculdade de Ciências Médicas da UNICAMP].

88. Popper K. The logic of scientific discovery. New York: Basic Books; 1959

89. Reis AOA. O discurso da saúde pública sobre a adolescente grávida: avatares. São Paulo; 1993. [Tese de Doutorado - Faculdade de Saúde Pública da USP]

90. Reis AOA, Zioni F. O lugar do feminino na construção do conceito de adolescência. Rev Saúde Pública 1993; 27(6): 472-7.

91. Reis J. A comparison of young teenage, older teenage, and adult mothers on determinants of parenting. J Psychol 1989; 123(2):141-52.

92. Reis JS, Herz EJ. Correlates of adolescent parenting. Adolescence 1987; $22(87):$ 599-609.

93. Rosenberg F. Comentários sobre o painel II: conseqüências e perspectivas da gravidez na adolescência. In: Seminário Gravidez na Adolescência; 1998 jul 30-31; Rio de Janeiro, Brasil. São Paulo: Associação Saúde da Familia; 1998. P. 92-7. 
94. Rothenberg PB, Varga PE. The relationship between age of mother and child health and development. Am J Public Health 1981; 71(8): 810-7.

95. Rouquayrol MZ, Correia LL, Barbosa LMM, Xavier LGM, Oliveira JW, Fonseca W. Fatores de risco de natimortalidade em Fortaleza: um estudo de caso-controle. J Pediatr 1996; 72(6): 374-8.

96. Schilmoeller GL, Baranowski MD, Higgins BS. Long-term support and personal adjustments of adolescent and older mothers. Adolescence 1991; 26(104): 787-97.

97. Scholl TO, Hediger ML, Belsky DH. Prenatal care and maternal health during adolescent pregnancy: a review and meta-analysis. J Adolesc Health $1994 ; 15(6): 444-456$.

98. Scholl TO, Schall JI, Krueger PM, Hediger ML. Young maternal age and preterm labor. Ann Epidemiol 1997; 7(6): 400-6

99. Schor N, Lopez FA. Adolescência e anticoncepção. 2. Estudo de conhecimento e uso em puérperas internadas por parto ou aborto. Rev Saúde Pública 1990; 24(6): 506-12.

100. Sciarra DT, Ponterotto JG. Adolescent motherhood among low-income urban hispanics: familial considerations of mother-daughter dyads. Qual Health Research 1998; 8(6): 751-63

101. Scott JW. The sentiments of love and aspirations for marriage and their association with teenage sexual activity and pregnancy. Adolescence 1983; 18(72): 889-97. 
102. Siqueira A, Tanaka A. Mortalidade na adolescência, com especial referência à mortalidade materna. In: Coletânea sobre saúde reprodutiva do adolescente brasileiro. Brasília (DF); 1988. p. 35-42.

103. Sismondi P, Volante R, Giai M. El embarazo y el parto en la adolescente. Rev Chilena de Obstet Ginecol 1984; 49 (1): 41-45.

104. Sociedade Brasileira de Pediatria. Departamento Científico de Adolescência. Guia de Adolescência. Rio de Janeiro; 2001.

105. Stephen TD. Q-methodology in communication research. Commun Quater 1985; 33: 193-208.

106. Stephenson W. Technique of factor analysis [letter]. Nature 1935a; 136: 297.

107. Stephenson W. Correlating persons instead of tests. Character and Personality $1935 b ; 4: 17-24$.

108. Stephenson W. The study of behavior. Chicago: The University of Chicago Press; 1953

109. Stephenson W. Foundations of communication theory. Psychol Record 1969; 19: 65-82.

110. Stephenson W. The shame of science. Ethics Sci Med 1978; 5: 25-38.

111. Stephenson W. Newton's fifth rule and Q-methodology: application of educational psychology. Am Psychol 1980; 35: 882-9. 
112. Stevens-Simon C, Kelly L, Singer D. Absence of negative attitudes toward childbearing among pregnant teenagers. Arch Pediatr Adolesc Med 1996; 150: 1037-43.

113. Strobino DM, Ensminger ME, Kim YJ, Nanda J. Mechanisms for maternal age differences in birth weight. Am J Epidemiol 1995; 142(5): 504-14.

114. Tanner JM. Factors affecting the rate of growth and the age at puberty. Tanner JM, editor. Growth at adolescence. $2^{\text {nd }}$ ed. Oxford: Blackwell Scientific Publication; 1962. p. 94

115. Teti DM, Lamb ME. Socioeconomic and marital outcomes of adolescent marriage, adolescent childbirth, and their co-ocurrence. J Marriage \& Family 1989; 51: 203-12

116. The Johns Hopkins University. Programas de planejamento da familia. Populations Reports 1976; 10: J169-192.

117. The Johns Hopkins University. Programas de planejamento da família. Populations Reports 1985; 9: M353-65.

118. The Johns Hopkins University. Family Panning Programs. Populations Reports 1995; 41: J2-18

119. Theriot JG, Pecoraro AG, Ross-Reynolds J. Revelations of adolescent mothers: an intensive case-study approach. Adolescence 1991; 26(102): $349-60$. 
120. Thompson PJ, Powell MJ, Patterson RJ, Ellerbee SM. Adolescent parenting: outcomes and maternal perceptions. JOGNN 1995; 24(8): 7138

121. Wagner KD, Berenson A, Harding $\mathrm{O}$, Joiner $\mathrm{T}$. Attributional style and depression in pregnant teenagers. Am J Psychiatry 1998; 155(9): $1227-$ 33

122. Wigger U, Mrtek RG. Use of Q-technique to examine attitudes of entering pharmacy students toward their profession. Am J Pharm Educ $1994 ; 58: 8-15$

123. Winter JSD. Nutrition and the neuroendocrinology of puberty. In: Winick N, editor. Adolescent nutrition. New York: John Wiley \& Sons; 1982. p. $3-12$

124. Wolkind SN, Kruk S. Teenage pregnancy and motherhood. J Royal Soc Med 1985; 78: 112-6

125. Zuckerman B, Amaro H, Beardslee W. Mental health of adolescent mothers: the implications of depression and drug use. Dev Behav Pediatr 1987; 8: 111-6. 


\section{BIBLIOGRAFIA COMPLEMENTAR:}

1. Faculdade de Saúde Püblica da Universidade de São Paulo. Guia de apresentação de teses. São Paulo; 1998. 


\section{ANEXO 1 - CONSENTIMENTO INFORMADO E ESCLARECIDO - GRUPOS FOCAIS}

Eu, responsável pela menor autorizo que a mesma

participe de uma reunião de grupo, com outras adolescentes do sexo feminino da mesma idade.

Estou ciente que a reunião:

- terá duração aproximada de duas horas e se dará na Fundação Educacional Serra dos Órgãos (FESO), em dia e horário compatíveis com suas atividades escolares;

- tem por objetivo colher informações sobre alguns aspectos da vida cotidiana das adolescentes;

- faz parte de um projeto de pesquisa da Dra. Silvia Reis dos Santos, aluna do Programa de Doutorado da Faculdade de Saúde Pública da Universidade de São Paulo e professora da FESO.

Teresópolis, __ de setembro de 1998. 


\section{ANEXO 2 - CONCOURSE OF IDEAS}

1. Meu filho agora só quer ficar comigo; com outra pessoa ela chora.

2. Eu não quero agora ter outro filho de jeito nenhum.

3. Eu tenho ciúmes do meu filho com o meu marido.

4. Meu marido tem ciúmes de mim com meu filho.

5. Meu marido não quer que eu vá na casa da minha mãe.

6. Eu tô pensando em começar a trabalhar.

7. Quando falta dinheiro o neném fica doente e aí é pior.

8. A gente tem vergonha ou medo do que as pessoas vão falar.

9. A maternidade é fator de amadurecimento da mulher.

10. Ser pai parece que não amadurece o homem, como a mulher.

11. Aqui em casa, faço uma coisa, outra e o tempo não passa.

12. Eu lá na mãe não me sinto sozinha, tem sempre gente.

13. Em casa, o neném só quer ficar no meu colo, ou ao meu redor.

14. Está sendo um tempo feliz, divertido e também um tempo de perda de sono, frustração, irritabilidade e solidão.

15. Quando a gente tem neném, quem manda no sono da gente é ele.

16. Tá sendo difícil. Eu não paro nunca, sempre tô fazendo alguma coisa.

17. Hoje acho até engraçado de ter me preocupado com meu filho que ia nascer; estou aqui cuidando ele.

18. Estão todos bobos com o neném; a mãe então nem se fala.

19. Eu não gosto que as outras pessoas peguem o neném no colo. 
20. O pessoal quando chega aqui em casa vai direto ver o neném, nem pergunta como eu estou passando.

21. Eu fico preocupada quando saio e deixo alguém tomando conta do neném

22. Eu entrei na vida adulta quando o neném nasceu.

23. Tudo pra mim era festa, agora eu sou mais útil, mais madura.

24. Hoje eu me sinto mais eu.

25. Eu sou diferente das meninas da minha idade.

26. Tem muita guria aí, bem barriguda, com 15 anos.

27. Chega a dar pena essa gurias com umas baita dumas barriga. Mal elas sabem o que é acordar de madrugada.

28. Meu filho está dando os primeiros passinhos; nem engatinhou e já tá caminhando, é a coisa mais linda.

29. O amor do meu filho me faz sentir mais importante.

30. Gravidez na adolescência acontece em todo lugar.

31. É dificil ser mulher, o corpo tá feio.

32. Ser mulher é muita fofoca, é muita falação.

33. Nem penso em ficar grávida; se um já é dificil, imagina dois.

34. Estou perdendo a paciência com meu filho, principalmente no final do dia

35. As tarefas e responsabilidade de mãe no cuidado do meu filho são demais para mim.

36. Só porque eu sou mãe adolescente e cuido dele sozinha, todo mundo fica só falando?

37. O filho é meu, não deixo ninguém cuidar, eu é que cuido. 
38. Quero trabalhar pra não precisar depender dos outros.

39. Eu quero sair e não posso por causa do neném.

40. Enquanto eu estou com ele, tem sempre alguém pra me ajudar.

41. Eu me sinto responsável pela saúde do meu filho.

42. Se ele fica doente, vão dizer que eu não cuidei bem.

43. Sem o apoio familiar, é quase impossível sair da ratoeira da maternidade.

44. Eu quero me divertir; se pudesse dava ele pra alguém criar.

45. Eu estou curtindo meu filho pra caramba.

46. Meu filho só vai me trazer felicidade, amor e paz.

47. Meu filho me dá forças pra continuar minha luta na vida.

48. Se eu soubesse das conseqüências não teria sido mãe tão cedo.

49. Gosto de conversar com meu filho, mas de vez em quando preciso dar uns tapas ou falar mais alto; ele é muito levado.

50. Como mãe, eu tenho alguém pra cuidar.

51. Depois que o neném nasceu, eu me sinto mais próxima do meu companheiro.

52. Eu tou tão orgulhosa porque meu filho é muito desenvolvido.

53. Quando meu filho nasceu eu ganhei a liberdade.

54. No fim do dia, estou tão cansada e acabada que não dá nem vontade de transar

55. Ter filho tão cedo é errado.

56. O amor do meu filho é a coisa mais importante da vida.

57. O corpo muda muito, não volta mais não. A gente perde todas as roupas. 
58. Depois que o neném nasce, aquela paixão toda com o pai da criança vai pro espaço

59. É muito chato acordar de madrugada, mas agora já não é uma opção de não querer, agora tem que fazer.

60. O peito aumenta e os quadris ficam mais largos. A gente fica mais bonita, mais mulher.

61. Depois que o neném nasce, adeus passeios, bailes e bagunça. Não dá pra fazer mais nada.

62. O neném dá cada vez mais trabalho.

63. Antes a gente tem um monte de colegas, depois fica sozinha

64. Fofoca e intriga é o que mais tem. As pessoas ficam comentando se a gente bota um shortinho mais curto.

65. No início é difícil mas, depois que o neném nasce, a vida fica mais legal, mais alegre.

66. Agora não dá pra dizer que não sabe; tem que se cuidar pra não ficar grávida de novo.

67. Eu hoje tiro de letra esse negócio de ser mãe.

68. Antes de ficar grávida, eu era o alvo da atenção lá em casa. De repente, só dão atenção pro neném.

69. Ter filho na idade da gente é super normal e super comum.

70. Depois que o neném nasce, a gente curte mais passear num parque, essas coisas assim mais familia.

71. Se a gente tem filho assim tāo cedo é porque Deus quis. 
72. Às vezes é melhor ficar sem marido; homem xinga e reclama; não faz nada e a gente ainda tem que cuidar da criança.

73. As pessoas esperam demais de mim como mãe.

74. Fazer as coisas de casa com o neném é a maior zona; arruma, arruma e quando vê tá tudo bagunçado.

75. Ser mãe e dona-de-casa é muito legal.

76. Agora que eu sou mãe, as pessoas têm mais respeito por mim.

77. Se acontece alguma coisa com o neném, o pessoal bota logo a culpa na gente.

78. Agora que eu sei toda a preocupação que dá, é ruim querer ter outro filho $\log$.

79. Tem que tentar voltar pros estudos; sem estudo não dá pra melhorar de vida.

80. É muito legal ver o neném crescer, ensinar coisas pra ele.

81. Ser mãe é muito difícil, é muita responsabilidade.

82. Tem que respeitar o neném como pessoa, conversar e explicar as coisas pra ele.

83. Eu me preocupo com o nosso futuro, meu e dele.

84. Mesmo mãe, eu não me sinto igual aos adultos, que fazem tudo certinho, tudo sério.

85. Às vezes o neném dá nos nervos. Tem que tomar conta o tempo todo e ele não pára quieto.

86. A gente precisa muito da familia, antes e depois que o neném nasce

87. Trabalhar, ter sua casa e ser independente é o maior sonho pro futuro. 


\section{ANEXO 3 - Q SAMPLE}

1. Ser mãe é muito difícil, è muita responsabilidade.

2. Às vezes dá medo, uma tristeza, uma vontade de chorar.

3. Se a gente tem filho é porque Deus quis.

4. Ter um filho é a melhor coisa que pode acontecer na vida da gente.

5. O corpo muda muito, não volta mais não. A gente perde toda a roupa.

6. A gente fica mais bonita, mais mulher.

7. Os outros até ajudam, mas a mãe do neném é que sabe o que é melhor pro seu filho.

8. Às vezes vem o pensamento se outra pessoa não iria criar ele melhor.

9. Quando a gente percebe que está grávida, parece que o mundo vai acabar.

10. Tem muita menina novinha com barriga. É super normal.

11. O futuro preocupa, como vai ser nossa vida e a vida do nosso filho.

12. Quando a gente tem neném, quem manda no sono da gente é ele. Tem que acordar de madrugada sem reclamar.

13. E a maior falação, que a gente é isso, é aquilo. Dá muita raiva e muita vergonha.

14.É legal ser mãe bem novinha porque dá pra curtir bem o filho, e ficar amiga dele.

15. Eu não paro nunca. Estou sempre fazendo alguma coisa para o neném. Vivo cansada. 
16. Ter filho tão cedo é perder o melhor da juventude. Não pode sair nem se divertir.

17. O importante é poder trabalhar, ter uma casa e ser independente

18. A saúde do neném preocupa, se a gente vai conseguir fazer ele crescer sem problemas.

19. A gente fica mais próxima da familia. Dão mais carinho e amor.

20. Às vezes me dá vontade de pegar o menino e sumir. Não vai ser homem ou familia pra me segurar.

21. Quando o neném nasce, a gente ganha a liberdade.

22. Na hora de transar é bom, mas depois a gente paga pelos erros

23. Se pudesse, eu voltava atrás no tempo, para quando eu era mais inocente.

24. É bom ter logo outro filho, pra fazer companhia pra este daqui.

25. Adoro levar o neném pra passear. As pessoas mexem com ele, é super gracinha

26. A vida com meu filho é mais alegre, mais feliz.

27. A mãe novinha é tão boa mãe quanto a mãe mais velha.

28. Antes eu era o alvo das atenções. Agora só lembram do neném.

29. Logo que o neném nasce todo mundo dá a maior atenção. Depois a gente acaba ficando sozinha.

30. A vida ganha mais sentido. Tem alguém para a gente cuidar.

31. É tão bom ficar com o neném, ensinar tudo pra ele, ver ele crescer forte e bonito. 
32. As pessoas passam a te olhar com mais respeito. A gente fica mais importante.

33. Ser mãe não é tão difícil assim. No início a gente fica insegura, mas depois pega o jeito.

34. As pessoas esperam que a gente seja adulto, responsável, mas a gente ainda é criança, não sabe as coisas da vida.

35. Ficam olhando pra gente como se a gente não fosse normal.

36. Agora tem que se cuidar pra não pegar barriga. Não dá pra dizer que não sabe. 


\section{ANEXO 4 - CONSENTIMENTO INFORMADO E ESCLARECIDO - Q}

Eu, Sílvia Reis dos Santos, sou médica e aluna do Curso de Pós-Graduação da Faculdade de Saúde Pública da Universidade de São Paulo. Estou conduzindo um estudo chamado "As Vivências da Maternidade na Adolescência", e preciso conversar com mães de 10 a 15 anos de idades. Este estudo busca entender melhor de que forma jovens como você vivenciam a experiência de ser mãe. Desta forma, vou precisar fazer algumas perguntas e pedir que você leia umas frases e preencha um formulário. É possível que daqui a umas duas semanas nós tenhamos que nos encontrar novamente.

O estudo não irá interferir de nenhuma maneira com a atenção à saúde dispensada para você e seu filho. Se você não concordar em participar, não haverá nenhum problema ou prejuizo para o seu atendimento. As informações obtidas serão mantidas em sigilo, sem possibilidade de identificação do seu nome e de suas respostas por outras pessoas.

Você concorda em participar do estudo "As Vivências da Maternidade na Adolescência"?
$\operatorname{SIM}$
NÃO

Nome: Data: 


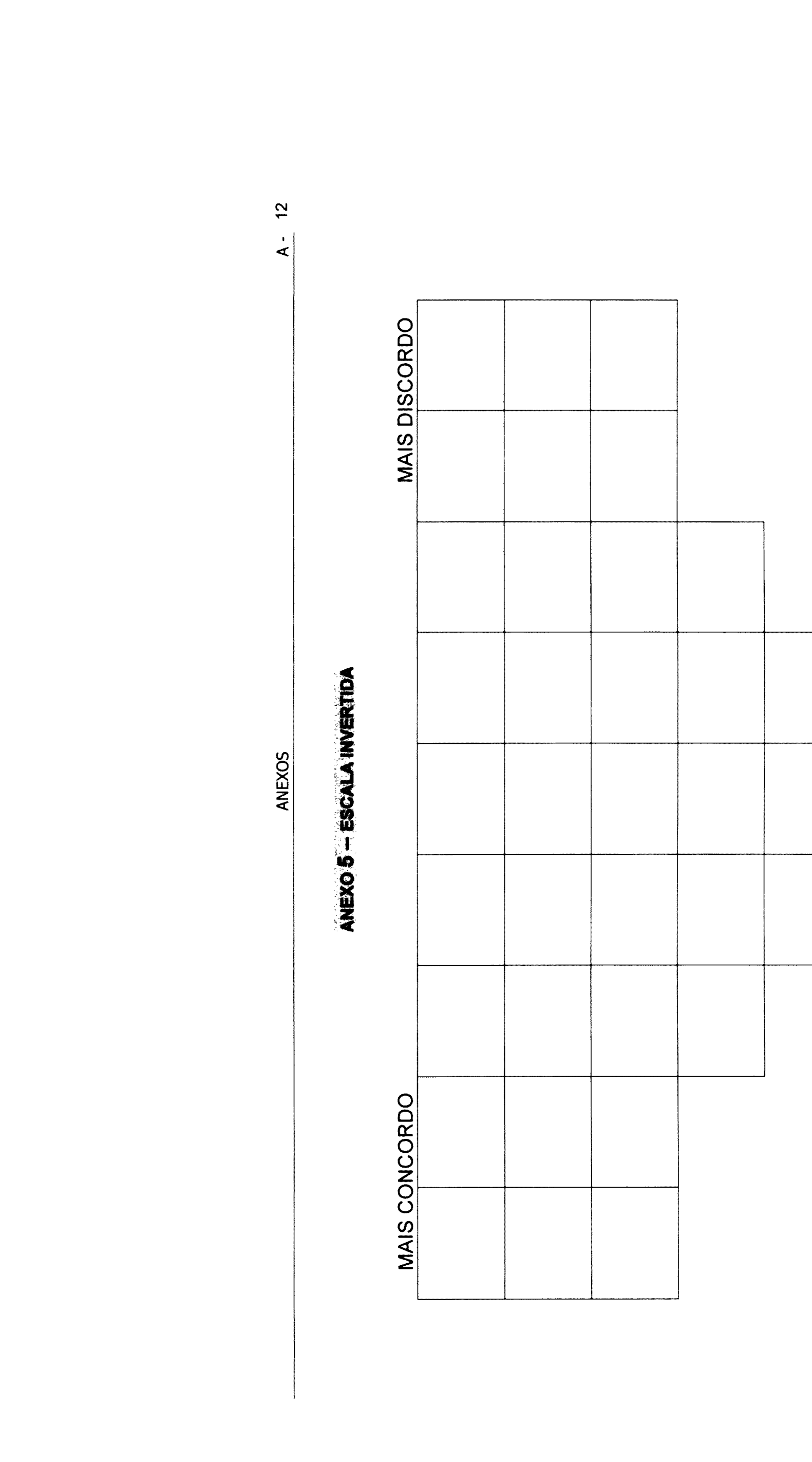




\section{ANEXO 6 - QUESTIONÁRIO}

A VIVÊNCIA DA MATERNIDADE NA ADOLESCÊNCIA - Data:

DADOS DEMOGRÁFICOS:

2. Nome da mãe:

2. Endereço:

Bairro: Cidade: Tel:

3. Idade: 4. Idade do pai da criança: Idade: anos

5. Data de nascimento da criança: 1 meses

SITUAÇÃo SÓCIO-ECONÓMICA-FAMILIAR:

6.Composição domiciliar:

7. Situação conjugal: $\square$ Com união conjugal

8. Situação de domicílio:

Dependente (+ 1 familia)

Próprio

9. Escolaridade:

Ainda estuda? Sim Última série completada:

10, Trabalho:

Está trabalhando com remuneração neste momento?

Sim. Em que? Renda:R\$

Não

12. Renda familiar:

Quem é (são) o(s) provedor(es) da familia?

Renda familiar?

HISTÓRIA DE GRAVIDEZ / PARTO E NEONATAL:

12. Gesta Para

13. Fêz pré-natal paral na gravidez da criança em questão?

Sim. Quantas consultas? Intercorrências? $\square$ Sim. Qual?

14. Tipo de parto? $\square$ Normal

Cesariana

Não

Não Intercorrência? $\square$ Sim. Qual?

15. Peso ao nascimentos: gramas

16. Amamentou? $\square$ Sim. Por quanto tempo? SeXUALIDADE:

17. Idade da primeira relação sexual: anos

18. Tem companheiro/namorado no momento atual? $\square \mathrm{Sim}$

Não

19. Tem vida sexual? $\square$ Sim

Não

20, Faz uso de algum MAC? $\square$ Sim. Qual?

22. Sua vida hoje è melhor ou pior do que antes de ficar grávida?

Por que? $\neg$ Pior

OBS: 


\section{ANEXO 7 - PERFIL DAS ADOLESCENTES ENTREVISTADAS (1A)}

\begin{tabular}{|c|c|c|c|c|c|c|c|c|c|c|c|c|c|c|}
\hline Nome & Unidade & Munic. & Bairro & $\begin{array}{l}\text { Idade } \\
\text { adol. }\end{array}$ & $\begin{array}{l}\text { Idade pai } \\
\text { criança }\end{array}$ & $\begin{array}{l}\text { Idade } \\
\text { criança }\end{array}$ & $\begin{array}{l}\text { Idade } 1^{a} \\
\text { relação } \\
\text { sexual }\end{array}$ & $\begin{array}{l}\text { Idade ficou } \\
\text { grávida }\end{array}$ & $\begin{array}{l}\text { Mora com o pai } \\
\text { da criança? }\end{array}$ & $\begin{array}{l}N^{\circ} \text { de fami-lias } \\
\text { no domicilio }\end{array}$ & $\begin{array}{l}\text { Domicilio } \\
\text { Próprio? }\end{array}$ & Estuda? & $\begin{array}{l}\text { Renda familiar } \\
\text { (em SM) }\end{array}$ & $\begin{array}{l}\text { Renda per capita } \\
\text { (em SM) }\end{array}$ \\
\hline 1.JAAS & IPPMG & RJ & Parque União & 15 & 21 & 11 & 12 & 13 & Sim & $>1$ & Sim & Não & 4,0 & 0,7 \\
\hline 2.PLAA & IPPMG & RJ & Parque União & 15 & 23 & 12 & 13 & 13 & Não & 1 & Não & Sim & 3,5 & 0,9 \\
\hline 3.RRC1 & IPPMG & $\mathrm{NI}$ & & 15 & 23 & 8 & 12 & 13 & $\operatorname{Sim}$ & 1 & Não & Não & 5,3 & 2,8 \\
\hline 4.LRB & IPPMG & RJ & Bonsucesso & 15 & 19 & 6 & 13 & 13 & Não & 1 & Sim & Sim & 2,0 & 0,5 \\
\hline 5.SPM & IPPMG & RJ & Parque União & 14 & 19 & 7 & 12 & 12 & Não & 1 & Sim & Sim & 4,7 & 2,2 \\
\hline 6.NVG & IPPMG & RJ & Parque União & 14 & 20 & 15 & 12 & 12 & Não & $>1$ & Sim & Não & 4,0 & 0,4 \\
\hline 7.JSB & IPPMG & RJ & Parque União & 15 & 19 & 23 & 12 & 13 & Não & 1 & Sim & Sim & 2,3 & 0,5 \\
\hline 8.RRC2 & IPPMG & RJ & Parque União & 15 & 17 & 7 & 13 & 13 & Não & 1 & Sim & Sim & 1,0 & 2,5 \\
\hline 9.DVRM & IPPMG & BR & & 15 & 17 & 11 & 12 & 13 & Não & 1 & Sim & Sim & 6,7 & 2,3 \\
\hline 10.ACF & IPPMG & $\mathrm{NI}$ & & 16 & 31 & 23 & 13 & 13 & Sim & 1 & Não & Não & 2,7 & 0,7 \\
\hline \multicolumn{15}{|c|}{$1 S M=R \$ 153,00$} \\
\hline
\end{tabular}




\section{ANEXO 7 - PERFIL DAS ADOLESCENTES ENTREVISTADAS (1B)}

\begin{tabular}{|c|c|c|c|c|c|c|c|c|c|c|c|c|c|c|}
\hline Nome & Unidade & Munic. & Bairro & $\begin{array}{l}\text { Idade } \\
\text { Adol. }\end{array}$ & $\begin{array}{l}\text { Idade pai } \\
\text { criança }\end{array}$ & $\begin{array}{l}\text { Idade } \\
\text { crianca }\end{array}$ & $\begin{array}{l}{\text { Idade } 1^{\bullet}} \\
\text { relaçäo } \\
\text { sexual }\end{array}$ & $\begin{array}{l}\text { Idade ficou } \\
\text { grávida }\end{array}$ & $\begin{array}{c}\text { Mora com o pai } \\
\text { da criança? }\end{array}$ & $\begin{array}{l}N^{0} \text { de fami-lias } \\
\text { no domicilio }\end{array}$ & $\begin{array}{l}\text { Domicilio } \\
\text { Próprio? }\end{array}$ & Estuda? & $\begin{array}{c}\text { Renda familiar } \\
\text { (em SM) }\end{array}$ & $\begin{array}{c}\text { Renda per capita } \\
\text { (em SM) }\end{array}$ \\
\hline 11.ICF & IPPMG & BR & & 15 & 18 & 6 & 13 & 13 & Não & 1 & Sim & Não & 5,2 & 0,7 \\
\hline 12.JCPN & IPPMG & $c X$ & & 15 & 22 & 13 & 12 & 13 & Sim & $>1$ & Sim & Não & 2,0 & 0,7 \\
\hline 13.wss & UISHL & RJ & Cidade Deus & 15 & 19 & 8 & 13 & 13 & Não & $>1$ & Sim & Não & 2,0 & 0,5 \\
\hline 14.VMC & UISHL & RJ & Cidade Deus & 15 & 17 & 15 & 13 & 13 & Não & $>1$ & Sim & Não & 2,0 & 0,25 \\
\hline 15.DA & UISHL & RJ & Cidade Deus & 15 & 19 & 15 & 13 & 13 & Não & $>1$ & Sim & Não & 2,7 & 0,5 \\
\hline 16.ASL & IPPMG & RJ & Bonsucesso & 15 & 18 & 6 & 13 & 13 & Sim & $>1$ & Sim & Sim & 4,0 & 0,7 \\
\hline 17.APS & IPPMG & $C X$ & & 15 & 15 & 6 & 12 & 13 & Não & 1 & Sim & Sim & 6,7 & 2,3 \\
\hline 18.DSD & UISHL & $\mathrm{RJ}$ & Cidade Deus & 15 & 19 & 6 & 13 & 13 & Não & $>1$ & Sim & Nẩo & 2,4 & 0,3 \\
\hline 19.CST & UISHL & RJ & Cidade Deus & 15 & 28 & 12 & 13 & 13 & Sim & 1 & Sim & Não & 2,7 & 0,9 \\
\hline 20.RSG & IPPMG & RJ & Vila Pinheiros & 16 & 21 & 22 & 12 & 13 & Sim & 1 & Nāo & Não & 3,0 & 2,0 \\
\hline
\end{tabular}

$1 \mathrm{SM}=\mathrm{R} \$ 153,00$

CX = Município de Duque de Caxias 


\section{ANEXO 7 - PERFIL DAS ADOLESCENTES ENTREVISTADAS (2A)}

\begin{tabular}{|c|c|c|c|c|c|c|c|c|c|c|c|}
\hline Nome & Gesta & Para & $\begin{array}{l}\mathrm{N}^{\circ} \text { con- } \\
\text { sultas no } \\
\text { pré-natal. }\end{array}$ & $\begin{array}{l}\text { Intercorréncias } \\
\text { no pré-natal? Quais? }\end{array}$ & $\begin{array}{l}\text { Tipo de } \\
\text { parto }\end{array}$ & $\begin{array}{l}\text { Intercorréncias } \\
\text { durante o } \\
\text { parto? Quais? }\end{array}$ & $\begin{array}{l}\text { Peso } \\
\text { Nascimento (g) }\end{array}$ & $\begin{array}{l}\text { Tempo Aleiteitamento } \\
\text { Exclusivo (dias) }\end{array}$ & $\begin{array}{l}\text { Tem namorado no } \\
\text { momento? }\end{array}$ & $\begin{array}{l}\text { Tem } \\
\text { vida sexual? }\end{array}$ & $\begin{array}{l}\text { Usa MAC? } \\
\text { Qual? }\end{array}$ \\
\hline 1.JAAS & 1 & 1 & 7 & Hiperemese & Cesáreo & Não & 3410 & 180 & Sim & Sim & Pilula \\
\hline 2.PLAA & 1 & 1 & 4 & Não & Normal & Não & 3055 & 60 & Sim & Sim & Pilula \\
\hline 3.RRC1 & 2 & 1 & 7 & Sangramento & Cesáreo & Pré-eclâmpsia & 2080 & 0 & Sim & $\mathrm{Sim}$ & Pilula \\
\hline 4.LRB & 1 & 1 & 4 & Não & Normal & Prematuridade & 2400 & 30 & Sim & Sim & Pilula \\
\hline 5.SPM & 1 & 1 & 9 & Não & Normal & Não & 3100 & 180 & Não & Não & Pilula \\
\hline 6.NVG & 1 & 1 & 5 & Não & Normal & Prematuridade & 2805 & 60 & Sim & Sim & Pílula \\
\hline 7.JSB & 1 & 1 & 9 & Ameaça parto prematuro & Cesáreo & Pré-eclâmpsia & 3030 & 210 & Não & Não & Não \\
\hline 8.RRC2 & 1 & 1 & 7 & Não & Cesáreo & Não & 3450 & 90 & Sim & Sim & Pilula \\
\hline 9.DVRM & 1 & 2 & 5 & Não & Cesáreo & Gêmeos & 2310 & 0 & Sim & Sim & Pilula \\
\hline 10.ACF & 2 & 2 & 6 & Não & Normal & Não & 3000 & 180 & Sim & Não & Não \\
\hline
\end{tabular}




\section{ANEXO 7 - PERFIL DAS ADOLESCENTES ENTREVISTADAS (2B)}

\begin{tabular}{|c|c|c|c|c|c|c|c|c|c|c|c|}
\hline Nome & Gesta & Para & $\begin{array}{l}\text { No con- } \\
\text { sultas no } \\
\text { pré-natal. }\end{array}$ & $\begin{array}{l}\text { Intercorrências } \\
\text { no pré-natal? Quais? }\end{array}$ & $\begin{array}{l}\text { Tipo de } \\
\text { parto }\end{array}$ & $\begin{array}{l}\text { Intercorrências } \\
\text { durante o } \\
\text { parto? Quais? }\end{array}$ & $\begin{array}{l}\text { Peso } \\
\text { Nascimento (g) }\end{array}$ & $\begin{array}{l}\text { Tempo Aleitamento } \\
\text { Exclusivo (dias) }\end{array}$ & Tem namorado no momento? & $\begin{array}{l}\text { Tem } \\
\text { vida sexual? }\end{array}$ & $\begin{array}{l}\text { Usa MAC? } \\
\text { Qual? }\end{array}$ \\
\hline 11.ICF & 1 & 1 & 6 & Verrugas na vagina & Cesáreo & Não & 2950 & 120 & Sim & Sim & Pílula \\
\hline 12. JCPN & 2 & 1 & 5 & Anemia & Cesáreo & Prematuridade & 1850 & 30 & Sim & Sim & Injeção \\
\hline 13. WSS & 1 & 1 & 8 & Não & Cesáreo & Pré-eclâmpsia & 4300 & 150 & Sim & Sim & Pilula \\
\hline 14.VMC & 2 & 1 & 5 & Não & Normal & Não & 3400 & 90 & Näo & Sim & Pílula \\
\hline 15.DA & 1 & 1 & 4 & Não & Normal & Não & 2870 & 180 & Sim & Sim & Pílula \\
\hline 16.ASL & 1 & 1 & 9 & Não & Cesáreo & Pré-eclâmpsia & 2890 & 90 & Sim & Sim & Condom \\
\hline 17.APS & 1 & 1 & 6 & Não & Normal & Prematuridade & 1905 & 60 & Não & Não & Não \\
\hline 18.DSD & 1 & 1 & 7 & Não & Normal & Não & 3210 & 90 & Não & Sim & Condom \\
\hline 19.CST & 2 & 1 & 6 & Não & Normal & Não & 3270 & 120 & Sim & Sim & Condom \\
\hline 20. RSG & 1 & 1 & 5 & Não & Normal & Não & 3180 & 90 & Sim & Sim & Pilula \\
\hline
\end{tabular}




\section{ANEXO 7- PERFIL DAS ADOLESCENTES ENTREVISTADAS (3A)}

\begin{tabular}{|c|c|c|c|}
\hline Nome & $\begin{array}{l}\text { Suavidahojeé mehorou } \\
\text { pior? }\end{array}$ & Por que? & Depoimentos \\
\hline 1.JAAS & Pior & Seria mais simples; é muita responsabilidade & $\begin{array}{l}\text { É muita solidão, não tenho amigos; fico em casa sozinha; meu marido } \\
\text { não quer que eu estude ou trabalhe; sofro calada, mas ele sai com os } \\
\text { amigos dele e eu não posso dizer nada }\end{array}$ \\
\hline 2.PLAA & Pior & $\begin{array}{l}\text { Teria mais liberdade; não gosto de pedir para } \\
\text { ficarem com o neném }\end{array}$ & $\begin{array}{l}\text { Minha avó é a minha amiga; meu marido me estimula para estudar, } \\
\text { diz que eu sou inteligente; ele quer casar, mas eu não quero porque } \\
\text { quero entrar para a Marinha }\end{array}$ \\
\hline 3.RRC1 & Pior & Teria mais liberdade & $\begin{array}{l}\text { A gravidez dele foi planejada; eu tive um aborto espontâneo antes e } \\
\text { quis logo pegar outro filho, mas pretendo voltar a estudar }\end{array}$ \\
\hline 4.LRB & Melhor & $\begin{array}{l}\text { Hoje tenho mais liberdade; é mais trabalho } \\
\text { mas sou mais feliz }\end{array}$ & A gravidez não foi planejada; meu companheiro está no serviço militar \\
\hline 5.SPM & Pior & $\begin{array}{l}\text { Filho prende muito; não posso me divertir, } \\
\text { mas quando estou longe dele é pior }\end{array}$ & A gravidez foi desejada, mais ou menos planejada \\
\hline 6.NVG & Pior & $\begin{array}{l}\text { Estaria na escola, e a vida seria mais fácil; ao } \\
\text { mesmo tempo hoje tenho mais liberdade; vou } \\
\text { a lugares que antes năo podia ir }\end{array}$ & Não falo com a minha mãe \\
\hline 7.JSB & Melhor & Hoje tenho mais coisas, mais liberdade & \\
\hline 8.RRC2 & Pior & $\begin{array}{l}\text { Teria mais coisas; hoje tenho que dividir, mas } \\
\text { não estou arrependida }\end{array}$ & Não tive festa de 15 anos; passei meus 15 anos na matemidade \\
\hline 9.DVRM & Pior & Teria mais tempo pra diversão e pros estudos & \\
\hline 10.ACF & Pior & Estaria estudando & $\begin{array}{l}\text { Na gravidez do outro correu tudo bem. Não fiz pré-natal na gravidez } \\
\text { da menina; foi cesariana, ela era prematura e ficou internada } 28 \text { dias. } \\
\text { Os médicos descobriram que ela tinha sifilis. e eu também. Em me } \\
\text { tratei, mas meu marido nem quer ouvir falar. Não tenho mais relações } \\
\text { com ele. }\end{array}$ \\
\hline
\end{tabular}




\section{ANEXO 7 - PERFIL DAS ADOLESCENTES ENTREVISTADAS (3B)}

\begin{tabular}{|c|c|c|c|}
\hline Nome & $\begin{array}{c}\text { Suavida hojeé melhorou } \\
\text { pior? }\end{array}$ & Por que? & Depoimentos \\
\hline 11.ICF & Pior & $\begin{array}{l}\text { Hoje tenho mais preocupação e menos liberdade } \\
\text { não teria que passar o que estou passando }\end{array}$ & \\
\hline 12. JCPN & Pior & $\begin{array}{l}\text { Poderia sair mais, me divertir, não estaria morando } \\
\text { com o pai da minha filha }\end{array}$ & $\begin{array}{l}\text { Na hora não pensei nas conseqüências; hoje não posso viver sem } \\
\text { minha filha; meu marido me estimula a estudar; não tive festa de } 15 \\
\text { anos; faço tudo sozinha, minha mãe não me ajuda }\end{array}$ \\
\hline 13. WSS & Pior & Teria mais liberdade e menos preocupação & \\
\hline 14. VMC & Pior & $\begin{array}{l}\text { Nâo ia ter a cabeça que tenho hoje; ia ser mais } \\
\text { avoada, mas a vida seria mais fácil, com menos } \\
\text { preocupação }\end{array}$ & \\
\hline 15. DA & $\begin{array}{l}\text { Nem melhor } \\
\text { nem pior }\end{array}$ & O que tenho que passar hoje, já passava antes & \\
\hline 16. ASL & Melhor & $\begin{array}{l}\text { Eu aprontava muito, fazia minha mâe sofrer, hoje } \\
\text { sou mais amiga dela }\end{array}$ & \\
\hline 17. APS & $\begin{array}{l}\text { Nem melhor } \\
\text { nem pior }\end{array}$ & $\begin{array}{l}\text { É ruim porque eu parei de estudar, mas é bom } \\
\text { porque hoje tenho meu filho }\end{array}$ & \\
\hline 18. DSD & Pior & Eu poderia trabalhar, estudar e ajudar minha mãe & \\
\hline 19. CST & Pior & Eu ia estar trabalhando e estudando & \\
\hline 20.RSG & $\begin{array}{l}\text { Nem melhor } \\
\text { nem pior }\end{array}$ & $\begin{array}{l}\text { Minha vida é igual; não me atrapalha em nada; meu } \\
\text { marido ajuda e vai pagar meu curso de informática }\end{array}$ & \\
\hline
\end{tabular}




\section{ANEXO 8 - PERFIL DAS ADOLESCENTES POR UNIDADE DE SAÚDE}

\begin{tabular}{|c|c|c|c|}
\hline Variável & IPPMG $(N=15)$ & UISHL $(N=5)$ & TOTAL $(N=20)$ \\
\hline Idade da adolescente (anos) * & $15,0 \pm 0,5$ & $15,0 \pm 0,0$ & $15,0 \pm 0,5$ \\
\hline Idade do pai da criança (anos) * & $20,2 \pm 3,8$ & $20,4 \pm 4,4$ & $20,3 \pm 3,8$ \\
\hline Idade da criança (meses) * & $11,7 \pm 6,3$ & $11,2 \pm 4,1$ & $11,6 \pm 5,8)$ \\
\hline Idade em que engravidou (anos) * & $12,9 \pm 0,4$ & $13,0 \pm 0,0$ & 12,9 anos $\pm 0,3$ \\
\hline Mora companheiro & $46,7 \%$ & $20,0 \%$ & $40,0 \%$ \\
\hline Domicilio independente (1 familia) & $73,3 \%$ & $20,0 \%$ & $60,0 \%$ \\
\hline Casa própria & $73,3 \%$ & $100,0 \%$ & $80,0 \%$ \\
\hline Está estudando & $53,3 \%$ & $0,0 \%$ & $40,0 \%$ \\
\hline Última série completada (série) * & $6,1 \pm 2,0$ & $5,8 \pm 0,8$ & $6,0 \pm 2,8$ \\
\hline Renda percapita * & $R \$ 148,30 \pm 86,40$ & $\mathrm{R} \$ 72,60 \pm 37,50$ & $R \$ 129,40 \pm 83,30$ \\
\hline Esta é a primeira gestação & $80,0 \%$ & $60,0 \%$ & $75,0 \%$ \\
\hline$N^{0}$ de consultas no pré-natal $\geq 6$ & $60,0 \%$ & $60,0 \%$ & $60,0 \%$ \\
\hline Intercorrências na gravidez & $33,3 \%$ & $0,0 \%$ & $25,0 \%$ \\
\hline Parto normal & $46,7 \%$ & $80,0 \%$ & $55,0 \%$ \\
\hline Intercorrências no parto & $46,7 \%$ & $20,0 \%$ & $40,0 \%$ \\
\hline Peso ao nascimento $<2500 \mathrm{~g}$ & $40,0 \%$ & $0,0 \%$ & $30,0 \%$ \\
\hline Md. tempo aleitam. exclusivo (dias) & 90,0 & 120,0 & 90,0 \\
\hline Idade $1^{\text {a }}$ relação sexual (anos) * & $12,4 \pm 0,5$ & $13,0 \pm 0,0$ & $12,5 \pm 0,5$ \\
\hline Tem namorado & $80,0 \%$ & $60,0 \%$ & $75,0 \%$ \\
\hline Tem vida sexual & $73,3 \%$ & $100,0 \%$ & $80,0 \%$ \\
\hline Faz uso de MAC & $80,0 \%$ & $100,0 \%$ & $85,0 \%$ \\
\hline MAC escolha e \% uso & Pílula $(83,3 \%)$ & Pilula $(60,0 \%)$ & Pilula $(76,5 \%)$ \\
\hline Vida hoje é melhor ou igual & $33,3 \%$ & $20,0 \%$ & $30,0 \%$ \\
\hline
\end{tabular}

* $\bar{x} \pm D P$ 


\section{ANEXO 9 - ANÁLISE FATORIAL (PQMETHOD)}

Correlation Matrix Between Sorts

SORTS

\begin{tabular}{|c|c|c|c|c|c|c|c|c|c|c|c|c|c|c|c|c|c|c|c|c|}
\hline & 1 & 2 & 3 & 4 & 5 & 6 & 7 & 8 & 9 & 10 & 11 & 12 & 13 & 14 & 15 & 16 & 17 & 18 & 19 & 20 \\
\hline jaas & 100 & 29 & -20 & 1 & 20 & 6 & 3 & -24 & -17 & 11 & 32 & 9 & -0 & 9 & 16 & 15 & 9 & 16 & -6 & 0 \\
\hline plaa & 29 & 100 & -20 & 1 & 31 & -33 & -4 & -8 & 6 & -1 & 0 & 9 & -19 & -3 & -11 & 14 & -14 & 33 & -18 & -4 \\
\hline rrcl & -20 & -20 & 100 & 60 & 5 & 34 & 28 & 62 & 44 & 47 & 36 & 40 & 67 & 50 & 55 & 46 & 44 & 18 & 67 & 78 \\
\hline lrb & 1 & 1 & 60 & 100 & 17 & 12 & 25 & 41 & 39 & 55 & 56 & 32 & 51 & 48 & 51. & 64 & 41 & 23 & 62 & 68 \\
\hline spm & 20 & 31 & 5 & 17 & 100 & -8 & -15 & 16 & 15 & 39 & 39 & 37 & 3 & 32 & 19 & 36 & 24 & 53 & 18 & \\
\hline nvg & 6 & -33 & 34 & 12 & -8 & 100 & 16 & 48 & 39 & 28 & 9 & 16 & 28 & 47 & 34 & 26 & 25 & -20 & 53 & 42 \\
\hline jsb & 3 & -4 & 28 & 25 & -15 & 16 & 100 & 23 & 28 & 22 & -3 & 3 & 33 & 38 & 37 & 49 & 18 & 8 & 23 & 1 \\
\hline rrc2 & -24 & -8 & 62 & 41 & 16 & 48 & 23 & 100 & 73 & 42 & 26 & 53 & 58 & 62 & 29 & 56 & 33 & 16 & 58 & \\
\hline dvm & -17 & 6 & 44 & 39 & 15 & 39 & 28 & 73 & 100 & 37 & 21 & 65 & 36 & 53 & $2:$ & 46 & 35 & 4 & 7 & \\
\hline $\operatorname{acf}$ & 11 & -1 & 47 & 55 & 39 & 28 & 22 & 42 & 37 & 100 & 48 & 50 & 52 & 72 & 6 & 73 & 66 & 41 & 42 & \\
\hline icf & 32 & 0 & 36 & 56 & 39 & 9 & -3 & 26 & 21 & 48 & 100 & 25 & 45 & 43 & 5 & 1 & 54 & 40 & 41 & \\
\hline jcpn & 9 & 9 & 40 & 32 & 37 & 16 & 3 & 53 & 65 & 50 & 25 & 100 & 31 & 47 & 28 & 35 & 33 & 29 & 42 & 19 \\
\hline ws & -6 & -19 & 67 & 51 & 3 & 28 & 33 & 58 & 36 & 52 & 45 & 31 & 100 & 47 & 62 & 54 & 57 & 19 & 46 & 9 \\
\hline vmc & 9 & -3 & 50 & 48 & 32 & 47 & 38 & 62 & 53 & 72 & 43 & 47 & 47 & 100 & 56 & 63 & 52 & 37 & 67 & 8 \\
\hline da & 16 & -11 & 55 & 51 & 19 & 34 & 37 & 29 & 22 & 65 & 56 & 28 & 62 & 56 & 100 & 65 & 57 & 40 & 49 & 54 \\
\hline asl & 15 & 14 & 46 & 64 & 36 & 26 & 49 & 56 & 46 & 73 & 51 & 35 & 54 & 63 & 65 & 100 & 39 & 30 & 55 & \\
\hline aps & 9 & -14 & 44 & 41 & 24 & 25 & 18 & 33 & 35 & 66 & 54 & 33 & 57 & 52 & 57 & 39 & 100 & 39 & 28 & \\
\hline dsd & 16 & 33 & 18 & 23 & 53 & -20 & 8 & 16 & 4 & 41 & 40 & 29 & 19 & 37 & 40 & 30 & 39 & 100 & 9 & \\
\hline st & -6 & -18 & 67 & 62 & 18 & 53 & 23 & 58 & 57 & 42 & 41 & 42 & 46 & 67 & 45 & 55 & 28 & 9 & 100 & \\
\hline $\mathrm{sg}$ & -8 & -4 & 72 & 58 & 7 & 42 & 31 & 75 & 67 & 47 & 39 & 49 & 59 & 58 & 54 & 56 & 46 & 23 & 65 & 0 \\
\hline
\end{tabular}




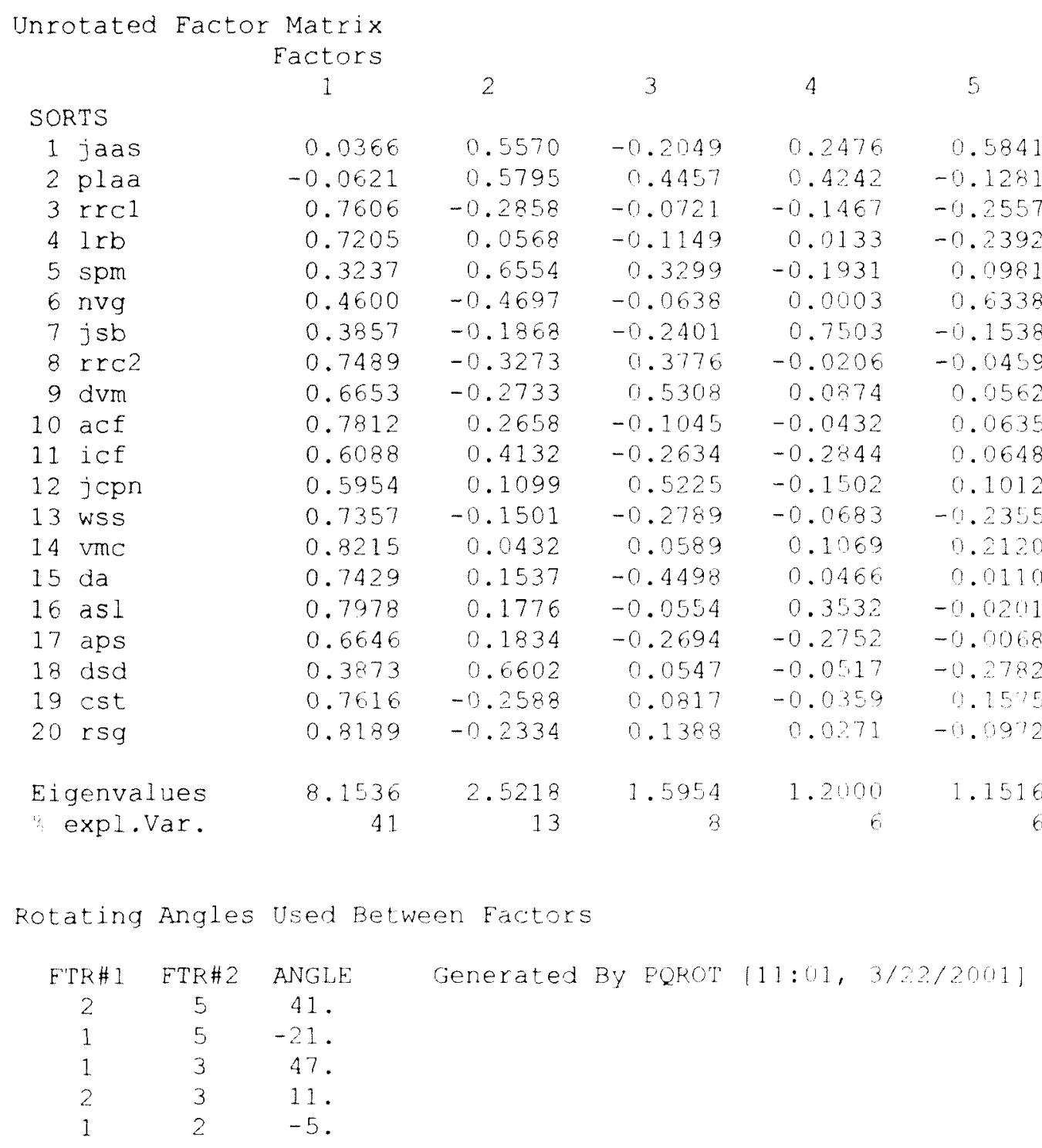



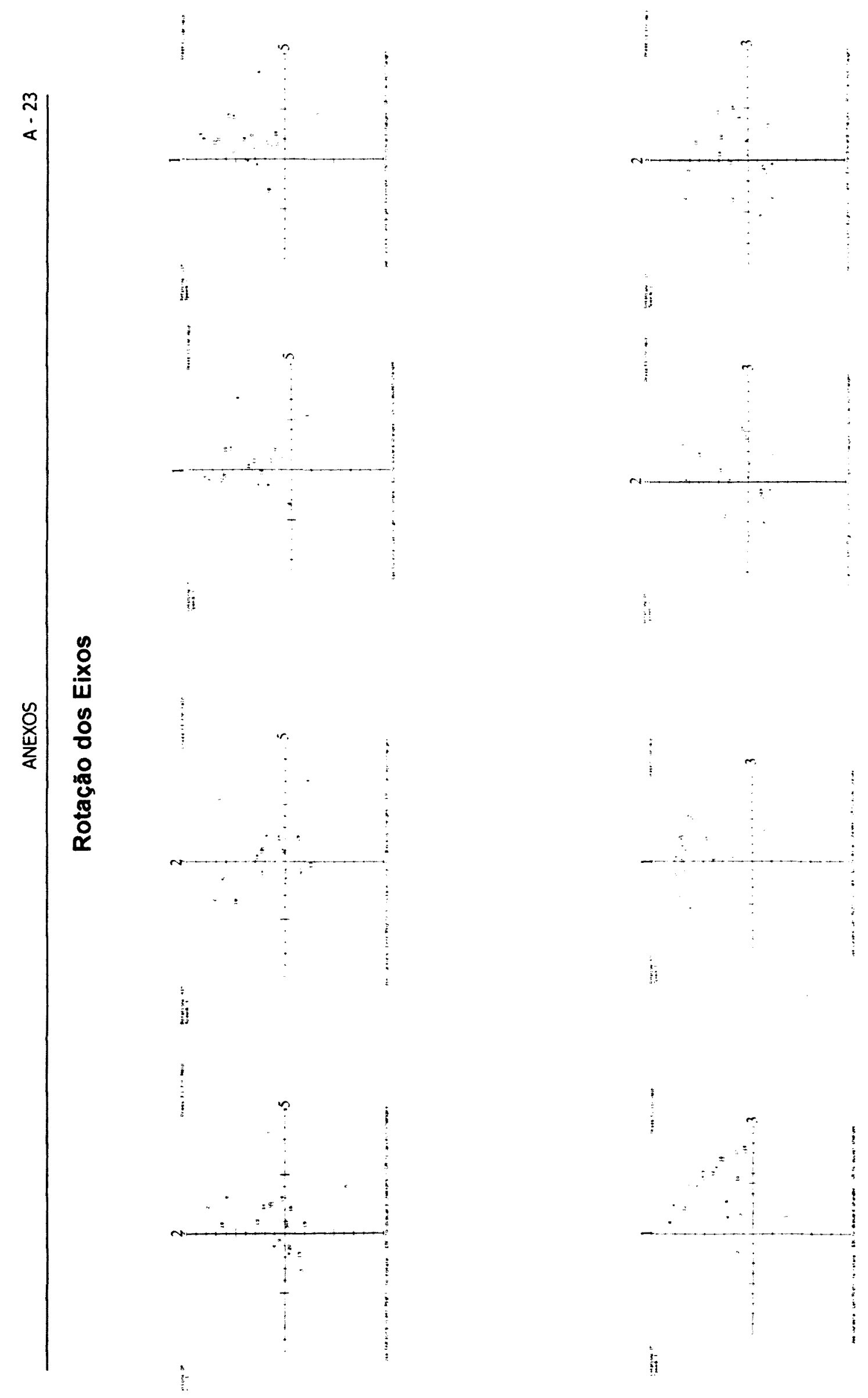
Factor Matrix with an $\mathrm{X}$ Indicating a Defining Sort

Loadings

\begin{tabular}{|c|c|c|c|c|c|}
\hline \multicolumn{2}{|c|}{ QSÓRT } & 1 & 2 & 3 & 4 \\
\hline \multicolumn{2}{|c|}{$3 \mathrm{rrcl}$} & $0.8063 x$ & -0.2665 & 0.1525 & 0.0297 \\
\hline 20 & rsg & $0.8044 \mathrm{X}$ & -0.1018 & 0.2183 & 0.1548 \\
\hline 8 & $x<c 2$ & $0.7646 \mathrm{X}$ & -0.1714 & 0.1053 & 0.1761 \\
\hline 13 & wss & $0.7361 x$ & -0.1422 & 0.2414 & 0.0367 \\
\hline 10 & $\operatorname{acf}$ & $0.7145 x$ & 0.3454 & 0.0787 & 0.1756 \\
\hline 4 & $\operatorname{lrb}$ & $0.7139 x$ & 0.0828 & 0.2281 & -0.0485 \\
\hline 14 & vmc & $0.7057 x$ & 0.2426 & 0.1886 & 0.3732 \\
\hline 19 & cst & $0.7052 x$ & -0.0908 & 0.1142 & 0.3853 \\
\hline 17 & aps & $0.6616 \mathrm{X}$ & 0.1571 & -0.0768 & 0.1156 \\
\hline 16 & as 1 & $0.6602 x$ & 0.3558 & 0.4597 & 0.1488 \\
\hline 9 & $d v m$ & $0.6514 \mathrm{X}$ & -0.0629 & 0.1113 & 0.2196 \\
\hline 15 & da & $0.6373 x$ & 0.2112 & 0.2769 & 0.2060 \\
\hline 12 & jcpn & $0.6225 x$ & 0.2253 & -0.1985 & 0.1168 \\
\hline 11 & icf & $0.5907 X$ & 0.3757 & -0.1588 & 0.0989 \\
\hline 1 & jaas & -0.1861 & $0.7064 x$ & 0.0445 & 0.4238 \\
\hline 5 & spm & 0.3454 & $0.6530 x$ & -0.3465 & -0.0860 \\
\hline 2 & plaa & -0.1031 & $0.6476 \mathrm{x}$ & 0.1635 & -0.3358 \\
\hline 18 & dsd & 0.4262 & $0.5784 x$ & -0.0517 & -0.3680 \\
\hline 7 & $j \mathrm{sb}$ & 0.1973 & 0.0166 & $0.8835 x$ & 0.0894 \\
\hline 6 & nvg & 0.3002 & -0.2101 & 0.0609 & $0.8341 x$ \\
\hline
\end{tabular}

$\begin{array}{llllll}\text { expl.var. } & 37 & 12 & 8 & 8\end{array}$ 
Rank Statement Totals with Each Factor

No. Statement

Ser mãe é muito difícil, é muita responsabilidade As vezes dá medo, uma tristeza, uma vontade de chorar Se a gente tem filho é porque Deus quis

Ter um filho é a melhor coisa que pode acontecer o corpo muda muito, não volta mais não.

A gente fica mais bonita, mais mulher

A mãe do neném é que sabe o que é melhor para o filho As vezes penso se outra pessoa iria criar ele melhor

9 Quando a gente percebe que esta grávida... mundo vai Tem muita menina novinha com barriga. É super normal O futuro preocupa, como vai ser a nossa vida e do filho Quem manda no sono da gente é o neném

E a maior falação... Dá muita raiva e vergonha

É legal ser mãe novinha porque dá para curtir bem of Eu não paro nunca ... Vivo cansada

Ter filho tão cedo é perder o melhor da juventude o importante é poder trabalhar ... ser independente A saúde do neném preocupa...se ele vai crescer sem A gente fica mais próxima da familia. Dão mais a amor As vezes dá vontade de...sumir. Não vai ser...pra me Quando o neném nasce a gente ganha a liberdade

$\mathrm{Na}$ hora de transar é bom, depois a gente paga pelos se pudesse eu voltava atras... quando era mais inocente E bom ter logo outro filho, pra fazer companhia pra e Adoro levar o neném pra passear. As pessoas mexem com

A vida com meu filho é mais alegre, mais feliz

A mãe novinha é tão boa mãe quanto a mais velha Antes eu era o alvo das atenções. Agora só o neném

Logo que o neném nasce...maior atenção. Depois fica só A vida ganha mais sentido. Tem alguém pra gente cuidar E bom ficar com o neném, ensinar, ver ele crescer As pessoas te olham com mais respeito...fica mais impo Ser mãe não é tão difícil...No inicio... depois pega o As pessoas esperam que seja adulto...mas ainda é cri Ficam olhando como se a gente não fosse normal

Agora tem que se cuidar pra não pegar barriga
No.

1

Eactors

2

3

$\begin{array}{rrrrrrrr}-0.25 & 20 & 1.05 & 6 & 0.85 & 10 & -0.43 & 26 \\ -0.57 & 22 & 1.83 & 1 & -1.71 & 36 & -1.28 & 33 \\ 0.45 & 14 & 0.44 & 14 & -1.71 & 36 & 0.43 & 15 \\ 1.43 & 2 & -0.58 & 26 & 0.00 & 21 & 0.43 & 15 \\ -0.45 & 21 & -1.01 & 31 & 1.28 & 6 & -0.43 & 26 \\ 0.42 & 15 & -1.32 & 34 & -0.43 & 26 & 0.43 & 15 \\ 1.05 & 9 & 0.03 & 19 & 0.43 & 15 & 0.00 & 21 \\ -1.44 & 36 & -0.65 & 27 & -0.43 & 26 & -0.43 & 26 \\ -0.66 & 23 & 0.78 & 11 & -0.43 & 26 & -0.43 & 26 \\ -0.11 & 19 & -0.97 & 30 & 0.00 & 21 & 1.71 & 3 \\ 1.22 & 7 & 1.52 & 2 & 0.00 & 21 & 0.00 & 21 \\ 0.01 & 17 & -0.03 & 20 & -0.85 & 30 & -1.71 & 36 \\ -0.78 & 27 & -1.06 & 32 & -0.85 & 30 & 1.71 & 3 \\ 0.89 & 10 & -0.19 & 23 & 0.00 & 21 & 0.85 & 10 \\ -0.66 & 24 & -0.15 & 22 & -0.85 & 30 & -1.71 & 36 \\ -1.28 & 32 & 0.78 & 10 & -1.28 & 33 & -0.85 & 30 \\ 1.23 & 6 & 1.08 & 5 & 0.00 & 21 & 0.43 & 15 \\ 1.29 & 5 & 0.97 & 7 & 0.43 & 15 & 0.00 & 21 \\ 0.55 & 13 & 0.04 & 17 & 1.71 & 3 & 0.85 & 10 \\ -1.31 & 34 & 1.47 & 3 & -1.28 & 33 & -0.85 & 30 \\ -0.69 & 25 & -2.13 & 35 & 0.00 & 21 & -1.71 & 36 \\ -1.07 & 30 & 0.49 & 12 & 1.71 & 3 & -0.85 & 30 \\ -0.77 & 26 & 0.19 & 16 & -0.43 & 26 & -0.43 & 26 \\ -1.05 & 29 & -2.49 & 36 & -1.28 & 33 & 0.43 & 15 \\ 0.84 & 11 & 0.03 & 18 & 0.43 & 15 & 0.00 & 21 \\ 1.31 & 4 & -0.14 & 21 & 0.85 & 10 & 0.00 & 21 \\ -0.04 & 18 & -1.17 & 33 & 0.43 & 15 & 1.71 & 3 \\ -1.39 & 35 & 0.89 & 8 & 0.85 & 10 & -0.85 & 30 \\ -1.18 & 31 & -0.71 & 28 & 1.71 & 3 & -1.28 & 33 \\ 1.32 & 3 & -0.89 & 29 & 0.85 & 10 & 1.28 & 6 \\ 1.80 & 1 & 0.44 & 13 & 1.28 & 6 & 0.00 & 21 \\ 0.24 & 16 & -0.42 & 25 & 0.43 & 15 & 0.85 & 10 \\ 1.15 & 8 & 1.10 & 4 & 1.28 & 6 & 1.28 & 6 \\ -0.83 & 28 & 0.22 & 15 & -0.85 & 30 & 1.28 & 6 \\ -1.29 & 33 & -0.29 & 24 & -1.71 & 36 & -1.28 & 33 \\ 0.63 & 12 & 0.86 & 9 & -0.43 & 26 & 0.85 & 10 \\ 0 & & & & 0.010\end{array}$


Correlations Between Factors

$\begin{array}{rrrrr}1 & 2 & 3 & 4 \\ 1.0000 & 0.1495 & 0.3539 & 0.4453 \\ 0.1495 & 1.0000 & -0.0351 & -0.1788 \\ 0.3539 & -0.0351 & 1.0000 & 0.1615 \\ 0.4453 & -0.1788 & 0.1615 & 1.0000\end{array}$


Normalized Factor Scores -- For Factor

No. statement

E bom ficar com o neném, ensinar, ver ele crescer

Ter um filho é a melhor coisa que pode acontecer

A vida ganha mais sentido. Tem alguém pra gente cuidar

A vida com meu filho é mais alegre, mais feliz

A saúde do neném preocupa... se ele vai crescer sem problemas

o importante é poder trabalhar ... ser independente

- futuro preocupa, como vai ser a nossa vida e do filho

Ser mãe não é tão difícil...No início...depois pega o jeito

A mãe do neném é que sabe o que é melhor para o filho

É legal ser mãe novinha porque dá para curtir bem o filho

Adoro levar o neném pra passear. As pessoas mexem com ele

Agora tem que se cuidar pra não pegar barriga

A gente fica mais próxima da familia. Dão mais ...e amor

Se a gente tem filho é porque Deus quis

A gente fica mais bonita, mais mulher

As pessoas te olham com mais respeito...fica mais importante Quem manda no sono da gente é o neném

A mãe novinha é tão boa mãe quanto a mais velha

Tem muita menina novinha com barriga. E super normal

Ser mãe é muito difícil, é muita responsabilidade

O corpo muda muito, não volta mais não.

Ass vezes dá medo, uma tristeza, uma vontade de chorar

9 Quando a gente percebe que esta grávida...o mundo vai acabar Eu não paro nunca ... Vivo cansada

Quando o neném nasce a gente ganha a liberdade

Se pudesse eu voltava atras... quando era mais inocente

É a maior falacão... dá muita raiva e vergonha

As pessoas esperam que seja adulto...mas ainda é crianca

É bom ter logo outro filho, pra fazer companhia pra este

$\mathrm{Na} h o r a$ de transar é bom, depois a gente paga pelos erros

Logo que o neném nasce...maior atencão. Depois fica sozinha

Ter filho tão cedo é perder o melhor da juventude

Ficam olhando como se a gente não fosse normal

As vezes dá vontade de...sumir. Não vai ser...pra me segurar

Antes eu era o alvo das atencões. Agora só o neném

As vezes penso se outra pessoa iria criar ele melhor
No.

Z-SCORES

1.801

1.425

1.323

1.310

1.294

1.230

1.222

1.152

1.049

0.892

0.836

0.628

0.549

0.452

0.423

0.242

0.005

$-0.041$

$-0.114$

$-0.250$

$-0.447$

$-0.571$

$-0.662$

$-0.654$

$-0.694$

$-0.768$

$-0.782$

$-0.827$

$-1.051$

$-1.070$

$-1.181$

$-1.282$

$-1.289$

$-1.313$

$-1.386$

$-1.441$ 
2 Às vezes dá medo, uma tristeza, uma vontade de chorar

1.831 o futuro preocupa, como vai ser a nossa vida e do filho

1.515

1.471

As vezes da vontade de...sumir. Não vai ser...pra me segurar

33 Ser mãe não é tão difícil...No início...depois pega o jeito

17 O importante é poder trabalhar ... ser independente

Ser mãe é muito dificil, é muita responsabilidade

1.097

1.079

1.049

0.971

0.894

0.858

0.781

Agora tem que se cuidar pra não pegar barriga

Ter filho tão cedo é perder o melhor da juventude

Quando a gente percebe que esta grávida...o mundo vai acabar Na hora de transar é bom, depois a gente paga pelos erros

É bom ficar com o neném, ensinar, ver ele crescer

Se a gente tem filho é porque Deus quis

34 As pessoas esperam que seja adulto...mas ainda é crianca

23 Se pudesse eu voltava atras... quando era mais inocente

A gente fica mais próxima da familia. Dão mais ...e amor

5 Adoro levar o neném pra passear. As pessoas mexem com ele

7 A mãe do neném é que sabe o que é melhor para o filho

12 Quem manda no sono da gente é o neném

26 A vida com meu filho é mais alegre, mais feliz

15 Eu não paro nunca... Vivo cansada

14 É legal ser mãe novinha porque dá para curtir bem o filho

Ficam olhando como se a gente não fosse normal

32 As pessoas te olham com mais respeito...fica mais importante Ter um filho é a melhor coisa que pode acontecer

Às vezes penso se outra pessoa iria criar ele melhor

29 Logo que o neném nasce...maior atenção. Depois fica sozinha

30 A vida ganha mais sentido. Tem alguém pra gente cuidar

10 Tem muita menina novinha com barriga. E super normal

5 o corpo muda muito, não volta mais não.

13 É a maior falacão... dá muita raiva e vergonha

27 A mãe novinha é tão boa mãe quanto a mais velha

6 A gente fica mais bonita, mais mulher

21 Quando o neném nasce a gente ganha a liberdade

24 É bom ter logo outro filho, pra fazer companhia pra este

0.780

0.493

0.440

0.439

0.216

0.188

0.037

0.034

0.033

$-0.033$

$-0.145$

$-0.153$

$-0.187$

$-0.293$

$-0.421$

$-0.585$

$-0.653$

$-0.710$

$-0.887$

$-0.973$

$-1.011$

$-1.058$

$-1.166$

$-1.318$

$-2.129$

$-2.487$ 
19 A gente fica mais próxima da familia. Dão mais ...e amor

22 Na hora de transar é bom, depois a gente paga pelos erros

Logo que o neném nasce...maior atencão. Depois fica sozinha

o corpo muda muito, não volta mais não.

31 É bom ficar com o neném, ensinar, ver ele crescer

33 Ser mãe não é tão difícil...No inicio...depois pega o jeito

1 Ser mãe é muito dificil, é muita responsabilidade

26 A vida com meu filho é mais alegre, mais feliz

28 Antes eu era o alvo das atencões. Agora só o neném

30 A vida ganha mais sentido. Tem alguém pra gente cuidar

18 A saúde do neném preocupa...se ele vai crescer sem problemas

7 A mãe do neném é que sabe o que é melhor para o filho

25 Adoro levar o neném pra passear. As pessoas mexem com ele

27 A mãe novinha é tão boa mãe quanto a mais velha

32 As pessoas te olham com mais respeito... fica mais importante

17 O importante é poder trabalhar ... ser independente

11 O futuro preocupa, como vai ser a nossa vida e do filho

21 Quando o neném nasce a gente ganha a liberdade

14 É legal ser mãe novinha porque dá para curtir bem o filho

10 Tem muita menina novinha com barriga. E super normal

4 Ter um filho é a melhor coisa que pode acontecer

23 Se pudesse eu voltava atras... quando era mais inocente

8 As vezes penso se outra pessoa iria criar ele melhor

9 Quando a gente percebe que esta grávida... mundo vai acabar

6 A gente fica mais bonita, mais mulher

36 Agora tem que se cuidar pra não pegar barriga

12 Quem manda no sono da gente é o neném

15 Eu não paro nunca ... Vivo cansada

13 E a maior falacão... dá muita raiva e vergonha

34 As pessoas esperam que seja adulto...mas ainda é crianca

16 Ter filho tão cedo é perder o melhor da juventude

24 E bom ter logo outro filho, pra fazer companhia pra este

20 Às vezes dá vontade de...sumir. Não vai ser...pra me segurar

3 Se a gente tem filho é porque Deus quis

35 Ficam olhando como se a gente não fosse normal

2 As vezes dá medo, uma tristeza, uma vontade de chorar

1.708

1.708

1.708

1.281

1.281

1.281

0.854

0.854

0.854

0.854

0.427

0.427

0.427

0.427

0.427

0.000

0.000

0.000

0.000

0.000

0.000

$-0.427$

$-0.427$

$-0.427$

$-0.427$

$-0.427$

$-0.854$

$-0.854$

$-0.854$

$-0.854$

$-1.281$

$-1.281$

$-1.281$

$-1.708$

$-1.708$

$-1.708$ 
10 Tem muita menina novinha com barriga. É super normal

E a maior falacão... dá muita raiva e vergonha

A mãe novinha é tão boa mãe quanto a mais velha

A vida ganha mais sentido. Tem alguém pra gente cuidar

1.708

1.708

1.281

Ser mãe não é tão difícil...No início...depois pega o jeito 33

As pessoas esperam que seja adulto...mas ainda é crianca 34

É legal ser mãe novinha porque dá para curtir bem o filho 14

A gente fica mais próxima da família. Dão mais ...e amor 19

As pessoas te olham com mais respeito...fica mais importante 32

Agora tem que se cuidar pra não pegar barriga

o importante é poder trabalhar ... ser independente

E bom ter logo outro filho, pra fazer companhia pra este

Se a gente tem filho é porque Deus quis

porque Deus qui

4 Ter um filho é a melhor coisa que pode acontecer

6 A gente fica mais bonita, mais mulher

11 O futuro preocupa, como vai ser a nossa vida e do fitho

8 A saúde do neném preocupa...se ele vai crescer sem problemas Adoro levar o neném pra passear. As pessoas mexem com ele

A vida com meu filho é mais alegre, mais feliz

A mãe do neném é que sabe o que é melhor para o filho

1 É bom ficar com o neném, ensinar, ver ele crescer

23 Se pudesse eu voltava atras...quando era mais inocente

Às vezes penso se outra pessoa iria criar ele melhor

9 Quando a gente percebe que esta grávida...o mundo vai acabar o corpo muda muito, não volta mais não.

Ser mãe é muito difícil, é muita responsabilidade

Antes eu era o alvo das atenções. Agora só o neném

Às vezes dá vontade de...sumir. Não vai ser...pra me segurar

Ter filho tão cedo é perder o melhor da juventude

Na hora de transar é bom, depois a gente paga pelos erros

Logo que o neném nasce...maior atenção. Depois fica sozinha

Ficam olhando como se a gente não fosse normal

Às vezes dá medo, uma tristeza, uma vontade de chorar

Eu não paro nunca ... Vivo cansada

Quem manda no sono da gente é o neném

1.281

1.281

0.854

0.854

0.854

0.854

0.427

0.427

0.427

0.427

0.427

0.000

0.000

0.000

0.000

0.000

0.000

$-0.427$

$-0.427$

$-0.427$

$-0.427$

$-0.427$

$-0.854$

$-0.854$

$-0.854$

$-0.854$

$-1.281$

$-1.281$

$-1.281$

$-1.708$

$-1.708$

21 Quando o neném nasce a gente ganha a liberdade 
No. Statement

30 A vida ganha mais sentido. Tem alguém pra gente cuidar Ter um filho é a melhor coisa que pode acontecer

A gente fica mais bonita, mais mulher

26 A vida com meu filho é mais alegre, mais feliz

24 E bom ter logo outro filho, pra fazer companhia pra este

Quando o neném nasce a gente ganha a liberdade

É bom ficar com o neném, ensinar, ver ele crescer

A mãe novinha é tão boa mãe quanto a mais velha

E legal ser mãe novinha porque dá para curtir bem o filho

A mãe do neném é que sabe o que é melhor para o filho

Tem muita menina novinha com barriga. É super normal

Adoro levar o neném pra passear. As pessoas mexem com ele

As pessoas te olham com mais respeito...fica mais importante

o corpo muda muito, não volta mais não.

A gente fica mais próxima da família. Dão mais ...e amor

A saúde do neném preocupa...se ele vai crescer sem problemas

E a maior falacão... dá muita raiva e vergonha

o importante é poder trabalhar ... ser independente

Ser mãe não é tão dificil...No início... depois pega o jeito

Quem manda no sono da gente é o neném

Se a gente tem filho é porque Deus quis

Agora tem que se cuidar pra não pegar barriga

o futuro preocupa, como vai ser a nossa vida e do filho

Logo que o neném nasce...maior atenção. Depois fica sozinha

Eu não paro nunca ... Vivo cansada

Às vezes penso se outra pessoa iria criar ele melhor

Se pudesse eu voltava atras... quando era mais inocente

Ficam olhando como se a gente não fosse normal

As pessoas esperam que seja adulto...mas ainda é crianca

Ser mãe é muito dificil, é muita responsabilidade

Quando a gente percebe que esta grávida...o mundo vai acabar

Na hora de transar é bom, depois a gente paga pelos erros

Ter filho tão cedo é perder o melhor da juventude

Antes eu era o alvo das atencões. Agora só o neném

Ass vezes dá medo, uma tristeza, uma vontade de chorar

20 Às vezes dá vontade de....sumir. Não vai ser...pra me segurar
No.

Type

$\begin{array}{rr}1.323 & -0.887 \\ 1.425 & -0.585 \\ 0.423 & -1.318 \\ 1.310 & -0.145 \\ -1.051 & -2.487 \\ -0.694 & -2.129 \\ 1.801 & 0.440 \\ -0.041 & -1.166 \\ 0.892 & -0.187 \\ 1.049 & 0.033 \\ -0.114 & -0.973 \\ 0.836 & 0.034 \\ 0.242 & -0.421 \\ -0.447 & -1.011 \\ 0.549 & 0.037 \\ 1.294 & 0.971 \\ -0.782 & -1.058 \\ 1.230 & 1.079 \\ 1.152 & 1.097 \\ 0.005 & -0.033 \\ 0.452 & 0.439 \\ 0.628 & 0.858 \\ 1.222 & 1.515 \\ -1.181 & -0.710 \\ -0.664 & -0.153 \\ -1.441 & -0.653 \\ -0.768 & 0.188 \\ -1.289 & -0.293 \\ -0.827 & 0.216 \\ -0.250 & 1.049 \\ -0.662 & 0.780 \\ -1.070 & 0.493 \\ -1.282 & 0.781 \\ -1.386 & 0.894 \\ -0.571 & 1.831 \\ -1.313 & 1.471 \\ & \end{array}$

Difference
2.210
2.010
1.741
1.454
1.436
1.435
1.361
1.125
1.079
1.016
0.859
0.802
0.663
0.564
0.512
0.323
0.275
0.151
0.055
0.038
0.012
-0.230
-0.293
-0.471
-0.511
-0.788
-0.956
-0.996
-1.043
-1.299
-1.442
-1.563
-2.063
-2.280
-2.402
-2.784
0 
No. Statement

3 Se a gente tem filho é porque Deus quis

4 Ter um filho é a melhor coisa que pode acontecer

17 O importante é poder trabalhar ... ser independente

11 O futuro preocupa, como vai ser a nossa vida e do filho

2 Às vezes dá medo, uma tristeza, uma vontade de chorar

36 Agora tem que se cuidar pra não pegar barriga

14 É legal ser mãe novinha porque dá para curtir bem o filho

18 A saúde do neném preocupa...se ele vai crescer sem problemas

12 Quem manda no sono da gente é o neném

6 A gente fica mais bonita, mais mulher

A mãe do neném é que sabe o que é melhor para o filho

31 É bom ficar com o neném, ensinar, ver ele crescer

30 A vida ganha mais sentido. Tem alguém pra gente cuidar

26 A vida com meu filho é mais alegre, mais feliz

35 Ficam olhando como se a gente não fosse normal

25 Adoro levar o neném pra passear. As pessoas mexem com ele

24 E bom ter logo outro filho, pra fazer companhia pra este

15 Eu não paro nunca ... Vivo cansada

13 É a maior falação... dá muita raiva e vergonha

34 As pessoas esperam que seja adulto...mas ainda é crianca

Ter filho tão cedo é perder o melhor da juventude

Às vezes dá vontade de...sumir. Não vai ser...pra me segurar Tem muita menina novinha com barriga. E super normal

Ser mãe não é tão dificil...No início...depois pega o jeito As pessoas te olham com mais respeito...fica mais importante Quando a gente percebe que esta grávida... mundo vai acabar Se pudesse eu voltava atras... quando era mais inocente

A mãe novinha é tão boa mãe quanto a mais velha

Quando o neném nasce a gente ganha a liberdade

As vezes penso se outra pessoa iria criar ele melhor

ser mãe é muito dificil, é muita responsabilidade

19 A gente fica mais próxima da familia. Dão mais ...e amor

o corpo muda muito, não volta mais não.

28 Antes eu era o alvo das atencões. Agora só o neném

22 Na hora de transar é bom, depois a gente paga pelos erros

29 Logo que o neném nasce...maior atenção. Depois fica sozinha
Type

$1.425 \quad 0.000 \quad 1.425$

$\begin{array}{lll}1.230 & 0.000 & 1.230\end{array}$

$\begin{array}{lll}1.222 & 0.000 & 1.222\end{array}$

$\begin{array}{lll}-0.571 & -1.708 & 1.137\end{array}$

$\begin{array}{lll}0.628 & -0.427 & 1.055\end{array}$

$0.892 \quad 0.000 \quad 0.892$

$\begin{array}{lll}1.294 & 0.427 & 0.867\end{array}$

$\begin{array}{lll}0.005 & -0.854 & 0.859\end{array}$

$\begin{array}{lll}0.423 & -0.427 & 0.850\end{array}$

$\begin{array}{lll}1.049 & 0.427 & 0.622\end{array}$

$\begin{array}{lll}1.801 & 1.281 & 0.520\end{array}$

$\begin{array}{lll}1.323 & 0.854 & 0.469\end{array}$

$\begin{array}{lll}1.310 & 0.854 & 0.456\end{array}$

$\begin{array}{lll}-1.289 & -1.708 & 0.419\end{array}$

$\begin{array}{lll}0.836 & 0.427 & 0.409\end{array}$

$-1.051 \quad-1.281 \quad 0.230$

$\begin{array}{lll}-0.664 & -0.854 & 0.190\end{array}$

$\begin{array}{lll}-0.782 & -0.854 & 0.071\end{array}$

$\begin{array}{lll}-0.827 & -0.854 & 0.027\end{array}$

$\begin{array}{lll}-1.282 & -1.281 & -0.001\end{array}$

$\begin{array}{lll}-1.313 & -1.281 & -0.033\end{array}$

$\begin{array}{lll}-0.114 & 0.000 & -0.114\end{array}$

$\begin{array}{lll}1.152 & 1.281 & -0.129\end{array}$

$\begin{array}{lll}0.242 & 0.427 & -0.185\end{array}$

$\begin{array}{lll}-0.662 & -0.427 & -0.235\end{array}$

$\begin{array}{lll}-0.768 & -0.427 & -0.341\end{array}$

$\begin{array}{lll}-0.041 & 0.427 & -0.468\end{array}$

$\begin{array}{lll}-0.694 & 0.000 & -0.694\end{array}$

$\begin{array}{lll}-1.441 & -0.427 & -1.014\end{array}$

$\begin{array}{lll}-0.250 & 0.854 & -1.104\end{array}$

$\begin{array}{rrr}0.549 & 1.708 & -1.159\end{array}$

$\begin{array}{lll}-0.447 & 1.281 & -1.728\end{array}$

$\begin{array}{lll}-1.386 & 0.854 & -2.240\end{array}$

$\begin{array}{lll}-1.070 & 1.708 & -2.778\end{array}$

$\begin{array}{lll}-1.181 & 1.708 & -2.889\end{array}$ 
Descending Array of Differences Between Factors 1 and 4

No. statement

31 E bom ficar com o neném, ensinar, ver ele crescer

12 Quem manda no sono da gente é o neném

26 A vida com meu filho é mais alegre, mais feliz

18 A saúde do neném preocupa...se ele vai crescer sem problemas

11 O futuro preocupa, como vai ser a nossa vida e do filho

7 A mãe do neném é que sabe o que é melhor para o filho

15 Eu não paro nunca ... Vivo cansada

21 Quando o neném nasce a gente ganha a liberdade

4 Ter um filho é a melhor coisa que pode acontecer

25 Adoro levar o neném pra passear. As pessoas mexem com ele

17 O importante é poder trabalhar ... ser independente

2 Às vezes dá medo, uma tristeza, uma vontade de chorar

1 Ser mãe é muito dificil, é muita responsabilidade

29 Logo que o neném nasce...maior atenção. Depois fica sozinha

30 A vida ganha mais sentido. Tem alguém pra gente cuidar

14 É legal ser mãe novinha porque dá para curtir bem o filho

Se a gente tem filho é porque Deus quis

A gente fica mais bonita, mais mulher

35 Ficam olhando como se a gente não fosse normal

5 o corpo muda muito, não volta mais não.

33 Ser mãe não é tão dificil... No início... depois pega o jeito

22 Na hora de transar é bom, depois a gente paga pelos erros

36 Agora tem que se cuidar pra não pegar barriga

9 Quando a gente percebe que esta grávida...o mundo vai acabar

19 A gente fica mais próxima da familia. Dão mais ...e amor

23 Se pudesse eu voltava atras...quando era mais inocente

16 Ter filho tão cedo é perder o melhor da juventude

20 Às vezes dá vontade de...sumir. Não vai ser...pra me segurar

28 Antes eu era o alvo das atenções. Agora só o neném

32 As pessoas te olham com mais respeito...fica mais importante

8 Às vezes penso se outra pessoa iria criar ele melhor

24 É bom ter logo outro filho, pra fazer companhia pra este

27 A mãe novinha é tão boa mãe quanto a mais velha

10 Tem muita menina novinha com barriga. É super normal

34 As pessoas esperam que seja adulto...mas ainda é crianca

13 É a maior falação... dá muita raiva e vergonha
1

Type

4

Difference

1.801

0.005

1. 310

1.294

1.222

1.049

$-0.664$

$-0.694$

1.425

0.836

1.230

$-0.571$

$-0.250$

$-1.181$

1.323

0.892

0.452

0.423

$-1.289$

$-0.447$

1.152

$-1.070$

0.628

$-0.662$

0.549

$-0.768$

$-1.282$

$-1.313$

$-1.386$

0.242

$-1.441$

$-1.051$

$-0.041$

$-0.114$

$-0.827$

$-1.708$

0.000

0.000

0.000

0.000

$-1.708$

$-1.708$

0.427

0.000

0.427

$-1.281$

$-0.427$

$-1.281$

1.281

0.854

0.427

0.427

$-1.281$

$-0.427$

1.281

$-0.854$

0.854

$-0.427$

0.854

$-0.427$

$-0.854$

$-0.854$

$-0.854$

0.854

$-0.427$

0.427

1.708

1.708

1.281

$-0.782 \quad 1.708$

1.801

1.713

1.310

1.294

1.222

1.049

1.044

1.014

0.998

0.836

0.804

0.710

0.177

0.100

0.042

0.038

0.025

$-0.004$

$-0.008$

$-0.020$

$-0.129$

$-0.216$

$-0.226$

$-0.235$

$-0.305$

$-0.341$

$-0.428$

$-0.460$

$-0.532$

$-0.612$

$-1.014$

$-1.478$

$-1.748$

$-1.822$

$-2.108$

$-2.490$ 
Descending Array of Differences Between Factors 2 and 3

\section{No. Statement}

2 Às vezes dá medo, uma tristeza, uma vontade de chorar

20 Às vezes dá vontade de...sumir. Não vai ser...pra me segurar Se a gente tem filho é porque Deus quis

16 Ter filho tão cedo é perder o melhor da juventude

11 O futuro preocupa, como vai ser a nossa vida e do filho

35 Ficam olhando como se a gente não fosse normal

36 Agora tem que se cuidar pra não pegar barriga

Quando a gente percebe que esta grávida...o mundo vai acabar

o importante é poder trabalhar... ser independente

As pessoas esperam que seja adulto...mas ainda é crianca Quem manda no sono da gente é o neném

Eu não paro nunca ... Vivo cansada

Se pudesse eu voltava atras... quando era mais inocente A saúde do neném preocupa... se ele vai crescer sem problemas Ser màe é muito difícil, é muita responsabilidade

Antes eu era o alvo das atencões. Agora só o neném

Ser mãe não è tão difícil...No início...depois pega o jeito É legal ser mãe novinha porque dá para curtir bem o filho

E a maior falacão... dá muita raiva e vergonha

Às vezes penso se outra pessoa iria criar ele melhor

25 Adoro levar o neném pra passear. As pessoas mexem com ele

A mãe do neném é que sabe o que é melhor para o filho

4 Ter um filho é a melhor coisa que pode acontecer

31 É bom ficar com o neném, ensinar, ver ele crescer

32 As pessoas te olham com mais respeito...fica mais importante A gente fica mais bonita, mais mulher

10 Tem muita menina novinha com barriga. É super normal

26 A vida com meu filho é mais alegre, mais feliz

24 E bom ter logo outro filho, pra fazer companhia pra este

22 Na hora de transar é bom, depois a gente paga pelos erros

27 A mãe novinha é tão boa mãe quanto a mais velha

19 A gente fica mais próxima da família. Dão mais ...e amor

30 A vida ganha mais sentido. Tem alquém pra gente cuidar

21 Quando o neném nasce a gente ganha a liberdade

5 O corpo muda muito, não volta mais não.

29 Logo que o neném nasce...maior atencão. Depois fica sozinha
No.

Type

$\begin{array}{rrr}1.831 & -1.708 & 3.539 \\ 1.471 & -1.281 & 2.751 \\ 0.439 & -1.708 & 2.147 \\ 0.781 & -1.281 & 2.062 \\ 1.515 & 0.000 & 1.515 \\ -0.293 & -1.708 & 1.415 \\ 0.858 & -0.427 & 1.285 \\ 0.780 & -0.427 & 1.207 \\ 1.079 & 0.000 & 1.079 \\ 0.216 & -0.854 & 1.070 \\ -0.033 & -0.854 & 0.821 \\ -0.153 & -0.854 & 0.701 \\ 0.188 & -0.427 & 0.615 \\ 0.971 & 0.427 & 0.544 \\ 1.049 & 0.854 & 0.195 \\ 0.894 & 0.854 & 0.040 \\ 1.097 & 1.281 & -0.184 \\ -0.187 & 0.000 & -0.187 \\ -1.058 & -0.854 & -0.204 \\ -0.653 & -0.427 & -0.226 \\ 0.034 & 0.427 & -0.393 \\ 0.033 & 0.427 & -0.393 \\ -0.585 & 0.000 & -0.585 \\ 0.440 & 1.281 & -0.841 \\ -0.421 & 0.427 & -0.847 \\ -1.318 & -0.427 & -0.891 \\ -0.973 & 0.000 & -0.973 \\ -0.145 & 0.854 & -0.999 \\ -2.487 & -1.281 & -1.206 \\ 0.493 & 1.708 & -1.215 \\ -1.166 & 0.427 & -1.593 \\ 0.037 & 1.708 & -1.671 \\ -0.887 & 0.854 & -1.741 \\ -2.129 & 0.000 & -2.129 \\ -1.011 & 1.281 & -2.292 \\ -0.710 & 1.708 & -2.418 \\ & & \\ 0.010 & & \end{array}$


Descending Array of Differences Between Factors 2 and

No. Statement

Às vezes dá medo, uma tristeza, uma vontade de chorar

20 Às vezes dá vontade de...sumir. Não vai ser...pra me segurar

14 ter um filho é a melhor coisa que pode acontecer

34 As pessoas esperam que seja adulto...mas ainda é crianca

32 As pessoas te olham com mais respeito...fica mais importante

6 A gente fica mais bonita, mais mulher

30 A vida ganha mais sentido. Tem alguém pra gente cuidar

10 Tem muita menina novinha com barriga. É super normal

13 É a maior falação... dá muita raiva e vergonha

27 A mãe novinha é tão boa mãe quanto a mais velha

24 É bom ter logo outro filho, pra fazer companhia pra este

$\begin{array}{rrr}1.831 & -1.281 & 3.112 \\ 1.471 & -0.854 & 2.325 \\ 0.894 & -0.854 & 1.748 \\ -0.033 & -1.708 & 1.675 \\ 0.781 & -0.854 & 1.635 \\ -0.153 & -1.708 & 1.555 \\ 1.515 & 0.000 & 1.515 \\ 1.049 & -0.427 & 1.476 \\ 0.493 & -0.854 & 1.347 \\ 0.780 & -0.427 & 1.207 \\ -0.293 & -1.281 & 0.988 \\ 0.971 & 0.000 & 0.971 \\ 1.079 & 0.427 & 0.653 \\ 0.188 & -0.427 & 0.615 \\ -0.710 & -1.281 & 0.571 \\ 0.440 & 0.000 & 0.440 \\ 0.034 & 0.000 & 0.034 \\ 0.033 & 0.000 & 0.033 \\ 0.439 & 0.427 & 0.012 \\ 0.858 & 0.854 & 0.004 \\ -0.145 & 0.000 & -0.145 \\ 1.097 & 1.281 & -0.184 \\ -0.653 & -0.427 & -0.226 \\ -2.129 & -1.708 & -0.421 \\ -1.011 & -0.427 & -0.584 \\ 0.037 & 0.854 & -0.817 \\ -0.585 & 0.427 & -1.012 \\ -0.187 & 0.854 & -1.041 \\ 0.216 & 1.281 & -1.065 \\ -0.421 & 0.854 & -1.274 \\ -1.318 & 0.427 & -1.745 \\ -0.887 & 1.281 & -2.168 \\ -0.973 & 1.708 & -2.681 \\ -1.058 & 1.708 & -2.766 \\ -1.166 & 1.708 & -2.874 \\ -2.487 & 0.427 & -2.914\end{array}$


Descending Array of Differences Between Factors 3 and 4

No. statement

29 Logo que o neném nasce...maior atencão. Depois fica sozinha $\mathrm{Na}$ hora de transar é bom, depois a gente paga pelos erros quando o neném nasce a gente ganha a liberdade

Antes eu era o alvo das atencões. Agora só o neném

o corpo muda muito, não volta mais não.

Ser mãe é muito difícil, é muita responsabilidade

É bom ficar com o neném, ensinar, ver ele crescer

Quem manda no sono da gente é o neném

Eu não paro nunca ... Vivo cansada

A vida com meu filho é mais alegre, mais feliz

A gente fica mais próxima da familia. Dão mais ...e amor

A saúde do neném preocupa...se ele vai crescer sem problemas

Adoro levar o neném pra passear. As pessoas mexem com ele

A mãe do neném é que sabe o que é melhor para o filho

Quando a gente percebe que esta grávida...o mundo vai acabar

Ass vezes penso se outra pessoa iria criar ele melhor

se pudesse eu voltava atras...quando era mais inocente

o futuro preocupa, como vai ser a nossa vida e do filho

Ser mãe não é tão difícil...No início...depois pega o jeito

As vezes dá vontade de... sumir. Não vai ser...pra me segurar

Ter filho tão cedo é perder o melhor da juventude

Às vezes dá medo, uma tristeza, uma vontade de chorar

35 Ficam olhando como se a gente não fosse normal

Ter um filho é a melhor coisa que pode acontecer

17 o importante é poder trabalhar ... ser independente

30 A vida ganha mais sentido. Tem alguém pra gente cuidar

32 As pessoas te olham com mais respeito...fica mais importante

6 A gente fica mais bonita, mais mulher

14 É legal ser mãe novinha porque dá para curtir bem o filho

36 Agora tem que se cuidar pra não pegar barriga

27 A mãe novinha é tão boa mãe quanto a mais velha

24 É bom ter logo outro filho, pra fazer companhia pra este

10 Tem muita menina novinha com barriga. E super normal

34 As pessoas esperam que seja adulto...mas ainda é crianca

3 Se a gente tem filho é porque Deus quis

13 É a maior falação... dá muita raiva e vergonha

Difference

$-1.281$

$-0.854$

$-1.708$

$-0.854$

$-0.427$

0.854

1.281

$-0.854$

$-0.854$

0.854

1.708

0.427

0.427

0.427

$-0.427$

$-0.427$

$-0.427$

0.000

1. 281

$-1.281$

$-1.281$

$-1.708$

$-1.708$

0.000

0.000

0.854

0.427

$-0.427$

0.000

$-0.427$

0.427

$-1.281$

0.000

$-0.854$

$-1.708$

$-0.427$

0.000

$-1.708$

$-1.708$

0.000

0.854

0.000

0.000

0.000

$-0.427$

$-0.427$

$-0.427$

0.000

1. 281

$-0.854$

$-0.854$

$-1.281$

$-1.281$

0.427

0.427

1. 281

0.854

0.427

0.854

0.854

1.708

0.427

1.708

1.281

0.427

$-0.854$

1. 708 
Factor Q-Sort Values for Each Statement

No. Statement

Ser mãe é muito difícil, é muita responsabilidade

2 As vezes dá medo, uma tristeza, uma vontade de chorar

3 Se a gente tem filho é porque Deus quis

4 Ter um filho é a melhor coisa que pode acontecer

o corpo muda muito, não volta mais não.

6 A gente fica mais bonita, mais mulher

A mãe do neném é que sabe o que é melhor para o filho

8 As vezes penso se outra pessoa iria criar ele melhor

9 Quando a gente percebe que esta grávida...o mundo vai acabar

10 Tem muita menina novinha com barriga. É super normal

11 O futuro preocupa, como vai ser a nossa vida e do filho

12 Quem manda no sono da gente é o neném

13 É a maior falação... dá muita raiva e vergonha

14 É legal ser mãe novinha porque dá para curtir bem o filho

15 Eu não paro nunca... Vivo cansada

16 Ter filho tão cedo é perder o melhor da juventude

17 O importante é poder trabalhar ... ser independente

18 A saúde do neném preocupa...se ele vai crescer sem problemas

19 A gente fica mais próxima da família. Dão mais ...e amor

20 Às vezes dá vontade de...sumir. Não vai ser...pra me segurar

21 Ouando o neném nasce a gente ganha a liberdade

22 Na hora de transar é bom, depois a gente paga pelos erros

23 Se pudesse eu voltava atras... quando era mais inocente

24 E bom ter logo outro filho, pra fazer companhia pra este

25 Adoro levar o neném pra passear. As pessoas mexem com ele

26 A vida com meu filho é mais alegre, mais feliz

27 A mãe novinha é tão boa mãe quanto a mais velha

28 Antes eu era 0 alvo das atenções. Agora só o neném

29 Logo que o neném nasce...maior atencão. Depois fica sozinha

30 A vida ganha mais sentido. Tem alguém pra gente cuidar

31 E bom ficar com o neném, ensinar, ver ele crescer

32 As pessoas te olham com mais respeito...fica mais importante

33 Ser mãe não é tão dificil...No início...depois pega o jeito

34 As pessoas esperam que seja adulto...mas ainda é crianca

35 Ficam olhando como se a gente não fosse normal

36 Agora tem que se cuidar pra não pegar barriga

\begin{tabular}{|c|c|c|c|c|}
\hline \multicolumn{5}{|c|}{ Factor Arrays } \\
\hline No. & 1 & 2 & 3 & 4 \\
\hline 1 & 0 & 3 & 2 & -1 \\
\hline 2 & -1 & 4 & -4 & -3 \\
\hline 3 & 1 & 1 & -4 & 1 \\
\hline 4 & 4 & -1 & 0 & 1 \\
\hline 5 & 0 & -3 & 3 & -1 \\
\hline 6 & 1 & -4 & -1 & 1 \\
\hline 7 & 2 & 0 & 1 & 0 \\
\hline 8 & -4 & -2 & -1 & -1 \\
\hline 9 & -1 & 1 & -1 & -1 \\
\hline 10 & 0 & -2 & 0 & 4 \\
\hline 11 & 2 & 4 & 0 & 0 \\
\hline 12 & 0 & 0 & -2 & -4 \\
\hline 13 & -2 & -3 & -2 & 4 \\
\hline 14 & 2 & -1 & 0 & 2 \\
\hline 15 & -1 & -1 & -2 & -4 \\
\hline 16 & -3 & 2 & -3 & -2 \\
\hline 17 & 3 & 3 & 0 & 1 \\
\hline 18 & 3 & 2 & 1 & 0 \\
\hline 19 & 1 & 0 & 4 & 2 \\
\hline 20 & -4 & 4 & -3 & -2 \\
\hline 21 & -1 & -4 & 0 & -4 \\
\hline 22 & -2 & 1 & 4 & -2 \\
\hline 23 & -1 & 0 & -1 & -1 \\
\hline 24 & -2 & -4 & -3 & 1 \\
\hline 25 & 1 & 0 & 1 & 0 \\
\hline 26 & 3 & 0 & 2 & 0 \\
\hline 27 & 0 & -3 & 1 & 4 \\
\hline 28 & -4 & 2 & 2 & -2 \\
\hline 29 & -3 & -2 & 4 & -3 \\
\hline 30 & 4 & -2 & 2 & 3 \\
\hline 31 & 4 & 1 & 3 & 0 \\
\hline 32 & 0 & -1 & 1 & 2 \\
\hline 33 & 2 & 3 & 3 & 3 \\
\hline 34 & -2 & 1 & -2 & 3 \\
\hline 35 & -3 & -1 & -4 & -3 \\
\hline 36 & 1 & 2 & -1 & 2 \\
\hline
\end{tabular}


Factor Q-sort Values for Statements sorted by Consensus vs. Disagreement (Variance across normalized Factor Scores)

No. Statement

Ser mãe não é tão difícil...No início...depois pega o jeito 33 Adoro levar o neném pra passear. As pessoas mexem com ele 25

Se pudesse eu voltava atras...quando era mais inocente 23

As vezes penso se outra pessoa iria criar ele melhor

A mãe do neném é que sabe o que é melhor para o filho

As pessoas te olham com mais respeito...fica mais importante

É legal ser mãe novinha porque dá para curtir bem o filho 14

A saúde do neném preocupa...se ele vai crescer sem problemas 18

o importante é poder trabalhar... ser independente 17

Ficam olhando como se a gente não fosse normal 35

Agora tem que se cuidar pra não pegar barriga 36

Eu não paro nunca ... Vivo cansada 15

Quando a gente percebe que esta grávida...o mundo vai acabar 9

A vida com meu filho é mais alegre, mais feliz 26

A gente fica mais próxima da familia. Dão mais ...e amor 19

Ser mãe é muito difícil, é muita responsabilidade

o futuro preocupa, como vai ser a nossa vida e do filho

Quem manda no sono da gente é o neném

É bom ficar com o neném, ensinar, ver ele crescer

A gente fica mais bonita, mais mulher

Ter um filho é a melhor coisa que pode acontecer

1 Quando o neném nasce a gente ganha a liberdade

6 Ter filho tão cedo é perder o melhor da juventude

o corpo muda muito, não volta mais não.

34 As pessoas esperam que seja adulto...mas ainda é crianca

30 A vida ganha mais sentido. Tem alguém pra gente cuidar

Se a gente tem filho é porque Deus quis

Tem muita menina novinha com barriga. É super normal

Antes eu era o alvo das atencões. Agora só o neném

A mãe novinha é tão boa mãe quanto a mais velha

É bom ter logo outro filho, pra fazer companhia pra este

Na hora de transar é bom, depois a gente paga pelos erros

É a maior falação... dá muita raiva e vergonha

As vezes dá vontade de...sumir. Não vai ser...pra me segurar Logo que o neném nasce...maior atenção. Depois fica sozinha

Ass vezes dá medo, uma tristeza, uma vontade de chorar
Eactor Arrays

\begin{tabular}{|c|c|c|}
\hline 1 & 2 & 3 \\
\hline 2 & 3 & 3 \\
\hline 1 & 0 & 1 \\
\hline-1 & 0 & -1 \\
\hline-4 & -2 & -1 \\
\hline 2 & 0 & 1 \\
\hline 0 & -1 & 1 \\
\hline 2 & -1 & 0 \\
\hline 3 & 2 & 1 \\
\hline 3 & 3 & 0 \\
\hline-3 & -1 & -4 \\
\hline 1 & 2 & -1 \\
\hline-1 & -1 & -2 \\
\hline-1 & 1 & -1 \\
\hline 3 & 0 & 2 \\
\hline 1 & 0 & 4 \\
\hline 0 & 3 & 2 \\
\hline 2 & 4 & 0 \\
\hline 0 & 0 & -2 \\
\hline 4 & 1 & 3 \\
\hline 1 & -4 & -1 \\
\hline 4 & -1 & 0 \\
\hline-1 & -4 & 0 \\
\hline-3 & 2 & -3 \\
\hline 0 & -3 & 3 \\
\hline-2 & 1 & -2 \\
\hline 4 & -2 & 2 \\
\hline 1 & 1 & -4 \\
\hline 0 & -2 & 0 \\
\hline-4 & 2 & 2 \\
\hline 0 & -3 & 1 \\
\hline-2 & -4 & -3 \\
\hline-2 & 1 & 4 \\
\hline-2 & -3 & -2 \\
\hline-4 & 4 & -3 \\
\hline-3 & -2 & 4 \\
\hline-1 & 4 & -4 \\
\hline
\end{tabular}


Factor Characteristics

$\begin{array}{lcccc} & 1 & 2 & 3 & 4 \\ \text { No. of Defining Variables } & 14 & 4 & 1 & 1 \\ \text { Average Rel. Coef. } & 0.800 & 0.800 & 0.800 & 0.800 \\ \text { Composite Reliability } & 0.982 & 0.941 & 0.800 & 0.800 \\ \text { S.E. of Factor Scores } & 0.132 & 0.243 & 0.447 & 0.447\end{array}$

Standard Errors for Differences in Normalized Factor Scores

(Diagonal Entries Are S.E. Within Factors)

$\begin{array}{ccccc}\text { Factors } & 1 & 2 & 3 & 4 \\ 1 & 0.187 & 0.276 & 0.466 & 0.466 \\ 2 & 0.276 & 0.343 & 0.509 & 0.509 \\ 3 & 0.466 & 0.509 & 0.632 & 0.632 \\ 4 & 0.466 & 0.509 & 0.632 & 0.632\end{array}$


Distinguishing Statements for Factor 1

$\left(\mathrm{P}<.05 ;\right.$ Asterisk $\left(^{*}\right)$ Indicates Significance at $\left.\mathrm{P}<.01\right)$

Both the Factor Q-Sort Value and the Normalized Score are Shown.

Factors

No. Statement

4 Ter um filho é a melhor coisa que pode acontecer

8 Às vezes penso se outra pessoa iria criar ele melhor
No

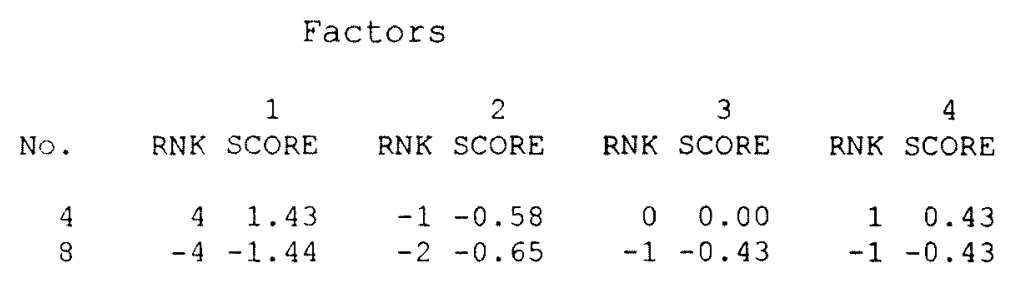

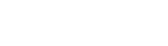

Distinguishing statements for Factor 2

$(\mathrm{P}<.05 ;$ Asterisk (*) Indicates Significance at $\mathrm{P}<.01)$

Both the Factor Q-sort Value and the Normalized Score are Shown.

\section{Factors}

No. Statement

2 Às vezes dá medo, uma tristeza, uma vontade de chorar

20 Às vezes dá vontade de...sumir. Năo vai ser...pra me segurar 20

16 Ter filho tão cedo é perder o melhor da juventude

9 Quando a gente percebe que esta grávida...o mundo vai acabar

22 Na hora de transar é bom, depois a gente paga pelos erros

34 As pessoas esperam que seja adulto...mas ainda é crianca

30 A vida ganha mais sentido. Tem alguem pra gente cuidar

27 A mãe novinha é tå boa mãe quanto a mais velha

$24 \mathrm{E}$ bom ter logo outro filho, pra fazer companhia pra este
No.

2

20
16

9
22
(1) RNK SCORE

$-1-0.57$

$\begin{array}{ll}-4 & -1.31\end{array}$

$\begin{array}{ll}-4 & -1.31 \\ -3 & -1.28\end{array}$

$\begin{array}{ll}-1 & -0.66\end{array}$

$-2-1.07$

$-2-0.83$

$4 \quad 1.32$

$0-0.04$

$-2-1.05$
2

RNK SCORE

$41.83^{\star} \quad-4-1.71$

$41.47^{\star} \quad-3-1.28$

$20.78 *-3-1.28$

$\begin{array}{llll}1 & 0.78 & -1 & -0.43\end{array}$

$\begin{array}{llll}1 & 0.49 & 4 & 1.71\end{array}$

$10.22 \quad-2 \quad-0.85$

$\begin{array}{llll}-2 & -0.89 * 2 & 2 & 0.85\end{array}$

$\begin{array}{llll}-3-1.17 * & 1 & 0.43\end{array}$

$\begin{array}{llll}-4 & -2.49 & -3 & -1.28\end{array}$
4
RNK SCORE

$-3-1.28$

$-2-0.85$

$-2-0.85$

$\begin{array}{ll}-1 & -0.43\end{array}$

$\begin{array}{ll}-2 & -0.85\end{array}$

31.28

31.28

41.71 
Distinguishing statements for Factor 3

$(\mathrm{P}<.05 ;$ Asterisk $(*)$ Indicates Significance at $\mathrm{P}<.01)$

Both the Factor Q-sort Value and the Normalized Score are shown.

Factors

No. Statement

22 Na hora de transar é bom, depois a gente paga pelos erros

29 Logo que o neném nasce...maior atença. Depois fica sozinha

5 o corpo muda muito, nå volta mais não.

36 Agora tem que se cuidar pra nå pegar barriga

3 se a gente tem filho é porque Deus quis

Distinguishing statements for Factor 4

$\left(\mathrm{P}<.05 ;\right.$ Asterisk $\left(^{*}\right)$ Indicates Significance at $\left.\mathrm{P}<.01\right)$

Both the Factor Q-sort Value and the Normalized Score are Shown.

\section{Factors}

No. Statement

10 Tem muita menina novinha com barriga. É super normal

13 É a maior falação... dá muita raiva e vergonha

27 A me novinha é ta boa mae quanto a mais velha

34 As pessoas esperam que seja adulto...mas ainda é crianca

$24 \dot{E}$ bom ter logo outro filho, pra fazer companhia pra este
NK SCORE

$$
\begin{array}{rr}
-2 & -1.07 \\
-3 & -1.18 \\
0 & -0.45 \\
1 & 0.63
\end{array}
$$

10.45
RNK SCORE

$$
\begin{array}{rr}
1 & 0.49 \\
-2 & -0.71 \\
-3 & -1.01
\end{array}
$$

10.44
RNK SCORE

$$
\begin{array}{rlrr}
4 & 1.71 & -2 & -0.85 \\
4 & 1.71 * & -3 & -1.28 \\
3 & 1.28 * & -1 & -0.43 \\
-1 & -0.43 & 2 & 0.85 \\
-4 & -1.71 * & 1 & 0.43
\end{array}
$$

RNK SCORE

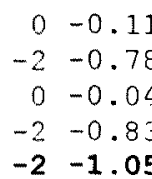

1
RNK SCORE

$$
-2-0.97
$$$$
-3-1.06
$$$$
-3-1.17
$$$$
1.0 .22
$$

$\begin{array}{rr}-4 & -2.49\end{array}$
2

RNK SCORE

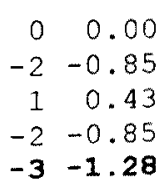

RNK SCORE

$\begin{array}{ll}4 & 1.71 * \\ 4 & 1.71^{*} \\ 4 & 1.71 \\ 3 & 1.28 \\ 1 & 0.43 *\end{array}$


Consensus statements -- Those That Do Not Distinguish Between ANY Pair of Factors.

All Listed Statements are Non-Significant at P>.01, and Those Flagged With an * are alsó Non-Significant at P>.05.

\section{No. Statement}

32 As pessoas te olham com mais respeito...fica mais importante 32 33* Ser mãe não é tão dificil...No inicio... depois pega o jeito 33

36 Agora tem que se cuidar pra não pegar barriga
RNK $\stackrel{1}{1}$ SCORE

00.24

$\begin{array}{ll}2 & 1.15 \\ 1 & 0.63\end{array}$
RNK SCORE

$-1-0.42$

$3 \quad 1.10$

20.86

\section{Factors}

RNK SCORE RNK SCORE

10.43

31.28

$\begin{array}{rr}-1 & -0.43\end{array}$
20.85

31.28

20.85 


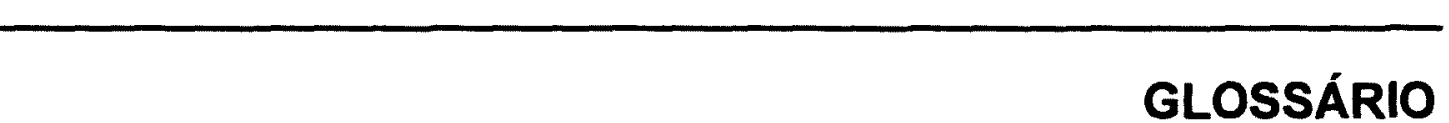


Análise fatorial $Q$ - forma grupos de respondentes ou casos baseados em suas semelhanças em uma série de características;

Análise fatorial $\mathbf{R}$ - analisa relações entre variáveis a fim de identificar grupos de variáveis que formam dimensões latentes (fatores);

Eigenvalue - representa a quantidade de variância por conta de cada fator;

Factor Loadings - correlação entre as variáveis originais e os fatores; a chave para a compreensão da natureza de um determinado fator; factor loadings ao quadrado indicam o percentual da variância numa variável original que é explicado pelo fator;

Factor score - medida de composição criada para cada observação de cada fator extraído na análise fatorial; o peso dos fatores são utilizados junto com os valores das variáveis originais para calcular cada escore. O factor score então pode ser utilizado para representar o fator em análises subsequentes;

Fator - combinação linear das variáveis originais; os fatores também representam as dimensões subjacentes (constructos) que sintetizam ou representam a série original de variáveis;

Q-Sorts - medidas da opinião de um respondente a respeito de um tópico subjetivo, dada uma determinada condição de instruçāo;

Varimax - método ortogonal de rotação de fatores. 